University of Miami Law School

University of Miami School of Law Institutional Repository

1989

Corporate Debt Relationships: Legal Theory in a Time of Restructuring

William Wilson Bratton

Follow this and additional works at: https://repository.law.miami.edu/fac_articles

Part of the Law Commons 


\title{
CORPORATE DEBT RELATIONSHIPS: LEGAL THEORY IN A TIME OF RESTRUCTURING
}

\author{
WiLliam W. Bratton, JR.*
}

INTRODUCTION.

I. Three CONCEPTIONS OF CORPORATE DebT-EquitY

RELATIONSHIPS .................................. 98

A. Overview .................................... 98

1. The Traditional Conception.................... 98

2. The Investment Conception .................... 99

3. The Agency Conception ........................ 100

4. Normative Contradictions..................... 100

B. The Traditional Conception-Corporate Debt as

Individual Debt ............................. 101

1. Doctrinal Models of the Corporate Debtor-Creditor Relationship .............................. 102

a. Debtor-creditor law and the mediation of conflicts ............................... 102

b. Debt and equity in the legal model of the corporation ................................... 103

2. Creditor-Protective Supplements................ 106

a. The rise and fall of creditor protection in corporate law........................... 106

b. Norms of creditor protection in corporate doctrine-equivocation in the traditional conception .............................. 109

C. Corporate Debt as Investment: The Realist Revision .... 113

1. Economics and History ...................... 113

2. The Investment Conception and Corporate Legal Theory ...................................... 115

D. The Traditional and Investment Conceptions as Competing Influences on the Development of Corporate Law

- Professor of Law, Benjamin N. Cardozo School of Law, Yeshiva University. The author gratefully acknowledges the support of Cardozo Law School's Samuel and Ronnie Heyman Center on Corporate Governance and thanks David Carlson, Drucilla Cornell, Karen Gross, Morey McDaniel, Paul Shupack, Elliott Weiss, and Charles Yablon for their comments on an earlier draft, and Ira Silfen and Josepl Tomkiexicz for research assistance. 
1. Depression-Era Reforms ..................... 115

2. Patterns from 1945 to $1980 \ldots \ldots \ldots \ldots \ldots \ldots . . . . .117$

a. Legal practice ........................... 117

b. Caselaw ............................. 117

i Fiduciary duties ....................... 118

ii. Contract duties .......................... 119

E. The Agency Conception: Corporate Debt as a Traded Security ...................................... 122

1. The Tenets of Financial Economics ............. 123

a. The irrelevance hypothesis, the efficient-market hypothesis, and the capital asset pricing model .................................... 124

b. Agency theory and the option pricing model ..... 125

2. Rebuttals of Received Legal Theory ............... 129

a. Rebuttal of the traditional conception ........... 129

b. Rebuttal of the investment conception .......... 130

3. The Normative Implications of Agency Theory ...... 130

a. The contractual hierarchy.................. 130

b. Financial economics at various points in the hierarchy-neoclassical and institutional models and their respective implications for legal theory ................................... 131

i. Neoclassical models ..................... 132

ii. Institutional models .................... 132

iii. Connections with the traditional and investment conceptions ................. 133

F. Summary ................................ 134

II. Conceptions of CoRporate Debt, Bondholder

Wealth Transfers, and High Debt-Equity Ratios... 135

A. Bondholder Wealth Transfers ................... 136

1. Restructuring and Bondholder Wealth Transfers.... 136

a. Incidence and magnitude ................... 136

b. The facilitating conditions: the disappearance of business covenants and the limited force of reputation ................................ 139

2. Legal Responses ........................... 143

a. The traditional conception ................. 143

b. The agency conception ..................... 144

c. The investment conception .................. 149

$i$ Fiduciary duty........................ 149

ii. The contracting process ................ 150 
3. The Traditional Conception as a Barrier to Deals: The Special Case of the Leveraged Buyout ........ 151

4. Responses in Business Practice .................. 155

5. Summary.................................. 158

B. High Leverage and Corporate Law ............... 159

1. The New Debt-Equity Ratios ................... 160

a. Evidence ................................ 160

b. Policy ................................. 162

2. High Leverage in Financial Theory and Practice.... 165

a. The managerialist view ..................... 165

b. The financial economic critique ............. 167

c. Managerialism and financial economics compared ............................... 168

CONCLUSION $. . \ldots \ldots \ldots \ldots \ldots \ldots \ldots \ldots \ldots \ldots \ldots \ldots, 170$

\section{INTRODUCTION}

On October 20,1988, the president of RJR Nabisco announced the "biggest deal ever": he was, he said, "considering" taking his firm private in a $\$ 17.6$ billion leveraged buyout. That day, the price of RJR Nabisco stock jumped \$21.38, to \$77.25. ${ }^{1}$ However, even as the news about RJR Nabisco buoyed the stock market with prospects of easy money, it caused jitters in the bond market. Reynolds's bonds plummeted; soine fell as much as 20 poimts, or $\$ 200$ per $\$ 1000$ face value. ${ }^{2}$ Fear that the RJR deal heralded a wave of similar transactions caused a near halt to trading in high grade corporate bonds and proinpted a "flight to quality" by bond investors. ${ }^{3}$

The RJR Nabisco announceinent and these market reactions are emblenatic of debt-equity relations in this time of corporate restructuring. The RJR Nabisco buyout illustrates a pattern: restructuring firms borrow, they remit the proceeds to their equityholders, and the increased leverage mjures their existing debtholders. In effect, these transactions

1. RJR Nabisco Chief Considering Buy-Out of Concem for \$17.6 Billion, or \$75 a Share, Wall St. J., Oct. 21, 1988, at A3, col. 1. This announcement marked the beginning of the largest takeover battle in history. Rival bids succeeded one another until Kohlberg, Kravis, Roberts \& Coinpany claimed victory on Noveinber 30, 1988, with a bid of \$24.88 billion, or \$109 per share. History of the RJR Takeover, N.Y. Times, Dec. 2, 1988, at D15, col. 3.

2. Winkler, Wall Street is Devising the Takeover-Proof Bond, Wall St. J., Nov. 3, 1988, at C1, col. 3; see also Gilpin, Bid for RJR Nabisco Jolts Bonds. N.Y. Times, Oct. 21, 1988, at D11, col. 1.

3. Wallace, Buyouts Devastating Bondholders, N.Y. Times, Oct. 26, 1988, at Dl, col. 3. Investors fled to the bonds of issuers unlikely to be involved in restructuring transactions-utilities and European corporations. Herman \& Stine, Bonds Stage Rebound amid Declining Oil Prices and a Hint That the Fed Isn't Tightening Credit. Wall St. J., Oct. 21, 1988, at C21, col. 1. 
transfer wealth from injured debt to benefited equity. ${ }^{4}$

Many examples of restructuring-related injury preceded RJR Nabisco, but it took the RJR Nabisco shock to goad players in the bond markets into open combat. Before RJR Nabisco, bondholders complained about wealth transfers but did not act; they merely reshuffled their portfolios again and again as waves of restructuring upset their expectations. Despite repeated injury, they did not negotiate effective protection in the next generation of debt contracts. ${ }^{5}$ Nor did they pursue the matter in court. ${ }^{6}$ With RJR Nabisco the pattern changed. Market actors drafted and publicized contract provisions that effectively protected bondholders from restructuring-related wealth transfers. ${ }^{7}$ Finally, a inajor institutional debtholder filed a lawsuit. ${ }^{8}$ But it remains to be seen whether these nascent challenges can break the pattern of injury.

The challengers have an uphill battle. Before RJR Nabisco, bondholders' case against restructuring injury looked closed; indeed, it had never been opened. The issue had been settled at the level of business practice; that settleinent probably will persist. The investment and inanageinent communities have acknowledged no bondholder rights in the structure of their legal relationships-at least no rights that would interfere with restructurings. Investors and inanagers have left bondholders to take their chances with restructuring, just as they take their chances with mismanagement, inflation, and recession. Yet, no impairment of bonds as a financing vehicle seeins to have resulted. New corporate debt financing proceeds apace. Restructurings have pushed corporate debtequity ratios to historic highs; ${ }^{9}$ levels of indebtedness formerly thought unacceptably risky have becoine routine.

As this picture ennerges, lawmakers stand by, acquiescing silently. Yet nothing in legal theory dictates that they do so. In evaluating wealth transfers, lawmakers can draw on two coinpeting legal norms, selfprotection and legal protection. By choosing the latter norm, they can intervene to impose a bondholder-protective duty, supported by anple

4. For a more complete description of this phenomenon, see infra text accompanying notes 188-204.

5. See infra notes $269-79$ and accompanying text.

6. No judicial opinion squarely ruling on the wealth transfers has appeared.

7. See infra notes 280-84 and accompanying text.

8. The plaintiff is the Metropolitan Life Insurance Company. According to Metropolitan's chairman, John Creedon, "It's time somebody blew the whistle ...." Wallace, $A$ Bruising Battle over Bonds, N.Y. Tines, Nov. 27, 1988, § 3, at 1, col. 2, col. 3; see also Farrell, Miller \& Zigas, Bondholders Are Mad as Hell-and No Wonder, Bus. WK., Dec. 5, 1988, at 28 (lack of protection from covenants has driven aggrieved bondholders, including Metropolitan, into court).

9. See infra notes 291-95 and accompanying text. 
caselaw and commentary. ${ }^{10}$ Furthermore, debt-equity ratios have been regulated in the past. ${ }^{11}$

Disposition at the level of business practice is a singular treatment for the inulti-billion-dollar issue of investor protection posed by the restructuring-related wealth transfers. Yet, this approach shows every likelihood of persisting, despite questions raised in the wake of the RJR Nabisco restructuring. This Article endeavors to explain this treatinent of restructuring injury by applying a relational ${ }^{12}$ theory of corporate debt-equity relations.

This relational theory's foundation is the assertion that corporate debt relationships do not have clearly defined, objective meanings. Coinplex debtor-creditor relationships give rise to interpretive contingencies. Different observers offer different interpretations; these interpretations shape different conceptions of the relationship, both positive and normative. This Article identifies, distinguishes, and discusses three such interpretive conceptions, which compete in contemporary corporate law and business practice. The first, the "traditional" conception, applies the relational assumptions underlying traditional debtor-creditor law. The second, the "investment" conception, views creditors as investors in corporate borrowers and applies the ideology of investor protection. The third, the "agency" conception, views debt as a traded security and applies the assumptions of financial economics.

No one of the three conceptions, taken alone, captures the corporate debt relationship's "essence." Despite this, lawinakers and commentators dealing with debt issues always apply one of the three conceptions to the others' exclusion, assuming that the chosen conception "is the case." By choosing a conception, they interpret, albeit inadvertently. In inter-

10. For an exposition of the case for a fiduciary duty for bondholders, see McDaniel, Bondhold. ers and Stockholders, 13 J. CORP. L. 205, 265-312 (1988) [hereinafter McDaniel, Bondholders II ]; McDaniel, Bondholders and Corporate Governance, 41 Bus. LAw. 413, 442-50 (1986) [hereinafter McDaniel, Bondholders I]. For an exposition of the case for a bondholder-protective duty of good faith under contract law, see Bratton, The Economics and Jurisprudence of Convertible Bonds, 1984 Wis. L. REv. 667, 691-98 [hereinafter Bratton, Convertible Bonds]; Bratton, The Interpretation of Contracts Governing Corporate Debt Relationships 5 CARDozo L. REV. 371 (1984) thereinafter Bratton, Interpretation].

11. See infra notes $256-58$ and accompanying text.

12. Ian Macneil's relational contract theory is a principal influence. See I. MACNE1h, THE New SOCIal Contract: AN InQuiry Into Modern Contractual Relations (1980); Macneil, Relational Contract Theory as Sociology: A Reply to Professors Lindenberg and de Vos, $143 \mathrm{~J}$. INST'L \& THEORETICAL ECON. 272 (1987); Macneil, Values in Contract: Intermal and Extemal, 78 Nw. U.L. REV. 340 (1983); Macneil, Economic Analysis of Contractual Relations: Its Shortfalls and the Need for a "Rich Classificatory Apparatus," 75 Nw. U.L. REv. 1018 (1981). I elaborate a broader application of relational contract principles in Bratton, The "Nexus of Contracts" Corporation: A Critical Appraisal, 74 CORNELL L. REv. - (forthcoming, 1989) [hereinafter Bratton, Nexus of Contracts Appraisal]. 
preting, they also adopt a normative approach. Norms influence and follow from the inadvertent interpretations, without acknowledgment. Deceivingly clear answers result. Failure to recognize the underlying interpretations prevents recognition of the weakness of the norms applied.

The Article, having identified these competing conceptions, demonstrates their influence on clioices between the competing norms of selfprotection and creditor protection. Lawmakers synchronize ${ }^{13}$ the norms by applying the conceptions; in turn, the evolving relational practices of the securities markets and corporate institutions shape and resliape the conceptions. A bondholder-protective right lies inchoate in the corporate debt relationship, no matter how interpreted. This right, although rarely determinative of legal rulings, persists as a critical supplement in a predominantly self-protective normative regime.

This framework shows us that the law tolerates restructuringrelated wealth transfers without giving them normative approbation. This tolerance derives from respect for market actors' relational practices-a respect that intensifies as the figure of the unprotected small investor takes a sinaller place in conceptions of corporate relationships. But the tolerance is conditional; it could yield to changes in the relational picture. A similar, but more watchful and skeptical tolerance greets the new debt-equity ratios.

The Article has two parts. Part I identifies the interpretive contingencies in the law of corporate debt. It describes and discusses the three competing conceptions and shows that norms of self-protection and creditor protection vary in intensity according to tlie conception being applied.14 Part II applies this relational framework to restructuringrelated wealth transfers and the new debt-equity ratios. It details the role that the three conceptions play in the legal and business commumities' responses to these developments. ${ }^{15}$ The Article concludes that restructuring-related wealth transfers and high debt pass normative inspection against today's relational background, but that an element of interpretive contingency persists. ${ }^{16}$ The discussion slows that recognizing the contingency in the law does not impair the day-to-day practices of capital raising. Ratler, this recognition enhances the law's ethical integrity.

13. For discussions of the jurisprudential significance of synchronization, see Cornell, Institutionalization of Meaning. Recollective Imagination and the Potential for Transformative Legal Interpretation, 136 U. PA. L. REv. 1135, 1210-12 (1988); Cornell, From the Lighthouse: The Promise of Redemption and the Possibility of Legal Interpretation, in LEGAl HERMENEUTICs (G. Leyh ed., forthcoming, 1989).

14. See infra notes 17-185 and accompanying text.

15. See infra notes $220-55,269-88$, and accompanying text.

16. See infra notes $220-55,341-46$, and accompanying text. 


\section{Three CONCEPTIONS OF CORPORATE Debt-Equity RELATIONSHIPS}

Debtors and creditors make a simple exchange. The creditor advances funds and receives a promise to repay with interest. Sometimes, however, this simple beginning leads to a complex relationship, particularly with large, long-term loans to major producing institutions such as "management corporations." 17 In these cases, the creditor can be another corporation, a simgle financial institution, a group of financial institutions, or a group of widely dispersed individuals and financial mstitutions. Relationships between management corporations and these large institutional lenders and bondholders are ongoing and complex. The easily grasped, objective meaning of the simple loan and promise to pay does not fully describe them. Nor do the concepts of "debtor" and "creditor" tell us everything about what these relationships mean to the participants. To understand these relationships adequately, we must look more closely at the parties and forward into time beyond the moment of promise.

Observers differ in their renderings of these complex debtor-creditor relationships. Different institutional perspectives influence these renderings. Today, three such interpretive conceptions-traditional, investinent, and agency-shape corporate debtor-creditor law. This part of the Article describes these conceptions, their competitive coexistence, and their respective roles in legal doctrime and theory. Normative contradiction pervades this story. Norms of self-protection and creditor protection compete within and among the three conceptions. Overall, selfprotection prevails, but never so fully as to become automatic or to obviate the ethical awkwardness of withholding legal protection from mjured creditors. Thus, normative contradiction persists. But, as the story shows, the contradiction is wholesome.

\section{A. Overview}

1. The Traditional Conception. The "traditional" conception incorporates a simple model of the debt exchange. It imposes this model on complex corporate debtor-creditor relationships, shaping them to make them fit.

The simple model has roots in pre-imdustrial history. It treats debt as an exchange between flesh-and-blood individuals. As an example, im-

17. A management corporation is a mass-producing corporation or other large corporate entity with widely held shares. See infra text accompanying note 51. This Article employs this term in preference to the usual term, "public corporation." 
agine a small-town banker who makes a loan to a local farmer. ${ }^{18}$ Debtor and creditor are personally acquainted and personally involved in the debt relationship. But they fear and suspect one another; no significant trust develops. In adversity, the banker will too readily foreclose. The farmer, ineanwhile, will too readily frustrate the banker by hiding or otherwise disposing of his property. Such opportunism, coming from either side, will enrage the imjured party. The law intervenes to prevent violence and generally to protect the mode of exchange from the participants' self-protective instincts. Legal rules responsive to this conception have shaped debtor-creditor doctrine throughout its history. They still dominate it now.

2. The Investment Conception. The "investment" conception has a very different archetype. Here the basic transaction is a publicly offered corporate bond issue with a long term-fifteen, twenty, or thirty years. The traditional picture of debtor and creditor as personal enemies does not accurately describe this transaction. With corporate bonds, no person-to-person encounters need occur. ${ }^{19}$ The debtor is a management corporation that issues a security, not an individual who signs a note. The creditor, whether an institution or an individnal, sees itself more as a securityholder than as an adverse lender. Relationships between issuers and securityholders tend to be depersonalized and objectified. Thus, the personal involvement and subjective responses of traditional, individual debtors and creditors do not shape "investments" in debt.

Managerialist theories of the corporation influence the investment conception. ${ }^{20}$ Managerialisin posits separation of stockholders' ownership and managers' control with concomitant stockholder passivity. Apphed to bonds, it depicts the creditor as simiply another investor outside the managerial power structure. In this model, the creditor has as much in cominon with a stockholder as it has with a traditional individual

18. This creditor's literary archetype is Shakespeare's Shylock, as Morey McDaniel has recently noted. See McDaniel, Bondholders II, supro note 10, at 258 \& n.439; see also W. SHARESPEARE, The Merchait of Ventce act I, sc. 3, 11. 140-50, act IV, sc. 1, 11. 184-310 (D. Bevington 3d ed 1980). For a philosophical construction of the traditional creditor and debtor, see F. NiETzSCHE, The Genealogy of Morals 70-82 (H. Samuel trans. 1924).

19. Some cases of corporate debt as investment do involve extensive personal relationships. Heavily negotiated bank loans and private placements are based on business relationships between managers of debtors and creditors. But even these relationships lack the intensity of the traditional debtor-creditor relationship. Since the individuals who negotiate bank loans and private placements act on behalf of institutional employers, they tend to limit their personal identification with any particular transaction.

20. For a description of the managerialist theory of the firm, see Bratton, Nexus of Contracts Appraisal, supra note 12 . 
lender, and perhaps more. The creditor joins a common enterprise with the managers and stockholders; cooperative spirit enters the relationship.

These cooperative norms coexist uneasily with the relationships' adverse elements. The paradigm of investor protection seeins to apply, because the bondholder is a powerless individual who rehes on corporate inanagement. But the relationship also has a basis in a negotiated contract, so the paradigm of imdividual self-protection, and even the norms of the traditional debtor-creditor relationship, also seein to apply. Corporate debtor-creditor law mediates this normative conflict.

3. The Agency Conception. The "agency" conception of corporate debtors and creditors comes froin financial economics. It now informs, even dommates, academic writing but as yet only slightly influences lawmaking.

Under the agency conception, the neoclassical microeconomic model of production by firms determines the interpretive gloss applied to loan transactions. Rational, profit-maximizing microeconomic actors populate this model.21 Conflicts of interest and self-protection by contract are presumed. As under the investinent conception, debt resembles stock, and the lender holds a depersonalized security. But liere the lender stands ready to trade that security at a inoment's notice in a perfect trading market. The model transforms the investment conception's long-term, cooperative loan into a fully objectified investinent in a diversified portfolio of securities. With this full "securitization," time horizons shorten, and possibilities for investor self-protection expand. The corporate borrower's institutional and inanageriahist characteristics lose their normative relevance. The normative question becomes whether any legal regulation should shape the contracting parties' beliavior.

4. Normative Contradictions. The three conceptions interact to form a larger legal picture. A norm of creditor self-protection informs all three conceptions, dominating the traditional and agency conceptions but merely supplementing the investment conception. This norm also dominates corporate debtor-creditor doctrime-in most cases, it determines the result. Yet it does not stand alone; a countervailing, creditorprotective norm almost always accoinpanies it. This creditor-protective norm plays a supplementary role in the traditional and agency conceptions as well as in legal doctrime, rarely determining results. It tends to play a determinative role only in academic renditions of the investment conception. ${ }^{22}$

21. See R. POSNER, ECoNomic ANAlysis of LAw 3-4 (3d ed. 1986).

22. See infra note 94 and accompanying text. 
The uneasy, imbalanced coexistence of these two norms follows from and reflects relational practices. Long-term corporate debt inevitably entails relational comphication. Parties in practice strive to minimize this complication. They structure their relationship to stay as much at arm's length as possible, using trust indentures, loan agreements, and other formidable documents. But they never fully succeed at transforming their debt relationships into discrete contracts. Even so, the law respects their attempts and applies the self-protective norm. If it did not, it would fail to uphold the values that parties bring to their relationships. Nornative contradiction enters in because, at the same time, lawmakers strive to accord full respect to the individuals involved in particular relationships, recognizing that, despite the prevalence of institutions, corporate debt-equity relationships ultimately involve real people. Legal norms recognize that these people are fallible. This leads decisionmakers to seek to offer such people protection, despite the fact that, viewed overall, the contracting process is oriented toward self-protection.

The self-protective element dominates the pattern of real world corporate debtor-creditor relationships. Faithful to these relationships, the law follows suit, privileging self-protection over creditor-protective legal intervention. But self-protection never becomes a doctrinal absolute, even as it tends to trump protective intervention in practice.

\section{B. The Traditional Conception-Corporate Debt as Individual Debt}

Corporate debtor-creditor doctrine, a subpart of corporate law, integrates basic principles of debtor-creditor law and the traditional legal inodel of the corporation. The traditional conception informs both of these doctrinal sources. Debtor-creditor law draws a line between traditionally conceived debtors and creditors. It mediates their adverse interests, protecting the solvent debtor from creditor interference and protecting the insolvent debtor's creditor from debtor misconduct. Corporate law's structural model assigns debt a fixed place: equity owns the corporation; corporate debt is a contractual relationship between the creditor and the corporation. The traditional mold casts this "contractual" creditor as an adverse party.

The doctrine of corporate creditors' rights, thus constituted, strongly reflects the norm of self-protection. It substantially constrains the legal protection of corporate creditors. Nevertheless, it has always carried an internal relational modification and has recognized creditor protection as a legitimate legal concern. Creditor protection has thus had a persistent, supplementing influence on corporate doctrine. 
1. Doctrinal Models of the Corporate Debtor-Creditor Relationship.

a. Debtor-creditor law and the mediation of conflicts. Debtorcreditor law mediates between debtors and creditors, defining zones of protected interest on each side and imposing proteetive rules. The debtor's interest is in autonomy-the freedom to manage his assets without creditor interference. ${ }^{23}$ This interest controls the relationship until the debtor becomes or is about to become insolvent. The law recognizes no impairment of a creditor's interest prior to a debtor's insolvency because, by definition, the debtor can still repay the loan. The balance shifts only when default becomes a certainty or a near-certainty. ${ }^{24}$ Of course, debtors who imsinanage property can inflict substantial damage on creditors well before insolvency, particularly when repayment depends on a going concern's cash flow. Nevertheless, the law holds to the policy of nonintervention. At the same time, lowever, it facilitates creditor control by enforcing their efforts to constrain debtor conduct by contract. ${ }^{25}$

Upon a debtor's insolvency, the creditors' interests prevail and the law imposes creditor-protective duties. The insolvent debtor's estate is administered for the creditors' benefit. ${ }^{26}$ And, at or near the point of msolvency, the law defines and prohibits debtor actions that injure creditors. ${ }^{27}$ In the corporate context, these rules tend to be characterized as "fiduciary."28 But that cliaracterization does not extend their creditorprotective reacl.

23. Carlson, Leveraged Buyouis in Bankruptcy, 20 GA. L. REv. 73, 77 (1985).

24. Bratton, Convertible Bonds, supra note 10, at 733.

25. Interestingly, in pre-industrial times, the policy of nonintervention prior to insolvency liad predominantly a creditor-protective effect. Long-term lending occurred only when secured by real estate, and a debtor's mismanagennent could do little permanent damage to the value of real property. No coinpelling reason for creditor intervention in debtor management existed. 1 A. DEWING, The Financial Policy of Corporations 189 n.kk (5th ed. 1953).

26. $1 \mathrm{id}$. at 190 n.00. No legal occasion for collective action by creditors arises prior to insolvency. But once the debtor is insolvent, payment of one claim necessarily prejudices otleer creditors. The law imposes the bankruptcy system in part to provide creditors witl a collective means of solving this preferential payinent problem. McCoid, Bankruptcy, Preferences, and Efficiency: An Expression of Doubt, 67 VA. L. REV. 249, 259-60 (1981).

27. This duty of creditor protection appears inost noticeably in fraudulent conveyance law. Carlson, supra note 23 , at 77-78.

28. For a classic statement of the corporate debtor-creditor norm, sec A. BERLE, STUDIES IN THE LAW OF CORPORATION FINANCE 157 n.3 (1928). According to Berle, a creditor has no standing to complain of a debtor corporation's management unless the debtor is insolvent, the debtor proposes a course of business that endangers its solvency, or its inanagement deliberately attempts to defraud complaining creditors. Berle notes that "[u]nder the stress of circumstances, . . . some courts have held that a corporate inanageinent has certain fiduciary obligations toward creditors... . [but] that eacli case turns on its facts." Id.; see also 1 A. DEwING, supra note 25, at 190 n.00 (courts will intervene to give creditors relief if there is implication of fraud or if creditors can show that debtor corporation is actually insolvent). 
b. Debt and equity in the legal model of the corporation. Corporate law associates equity interests with risk, control, and ownership; it leaves debt out of this association. This conception draws on classical economic theory, which modeled economic life in terms of production by individual producers and transactions between individuals, each bearing responsibility for his or her own actions. In the nineteenth century, corporate doctrine adapted this individual conception to group production, reconstructing the classical individual's entrepreneurial behavior pattern within the corporate structure. ${ }^{29}$ Under this view, the entrepreneurial mantle - the role of "adventurer"30_falls on the stockholder, conceived as an owner-manager. ${ }^{31}$ Among the corporate claimants, the stockholder faces the highest risk of loss and enjoys the highest potential for gain. As the "natural" concomitant of this extreme risk-return situation, a right to control accompanies ownership. ${ }^{32}$

Under this model, creditors jom the firm not as "owners" or "members," but as contractual suppliers of capital. The relationship is contractual in more than one sense. The exchange of money for a promise to pay at interest and the document recording that exchange are both "contracts." "Contract" also designates relational status: creditors, being "contractually" tied to the firm, are not members of the firm entity. An additional "contract," the paradigmatic bargain between the creditors and the corporation, justifies this status. The creditors trade incidents of ownership, like control and profit, first, for periodic payments made without regard to profit, and, second, for repayment of principal at a fixed date, with priority over the equityholders' claims to the corpora-

For an updated statement of the debtor-creditor norm, recast in the contractualist terms of the law and economics movement, see Baird \& Jackson, Fraudulent Conveyance Law and Its Proper Domain, 38 VAND. L. REv. 829, 836-37 (1985) (debtor-creditor law should constrain transactions that affect third parties and should establish preformulated provisions that parties would contract for anyway).

29. See Bratton, The New Economic Theory of the Firm: Critical Perspectives from History, 41 STAN. L. REv. — (forthcoming, 1989) [hereinafter Bratton, Historical Perspectives].

30. See the classic tax case enunciating this debt-equity distinction, Commissioner v. O.P.P. Holding Corp., 76 F.2d 11, 12 (2d Cir. 1935):

The stockholder is an adventurer in the corporate business; he takes the risk, and profits from success. The creditor, in compensation for not sharing the profits, is to be paid independenily of the risk of success, and gets a right to dip into the capital when the payment date arrives.

31. The crisis for classical microeconomic thinking came in the late nineteenth century when the ofner-entrepreneurs of large manufacturing corporations became passive, outside investors, and non-owner managers took control. See Bratton, Historical Perspectives, supra note 29, for a discussion of the role that this theoretical problem played in the evolution of corporate legal theory.

32. See Klein, The Modem Business Organization: Bargaining Under Constraints, 91 YalE L.J. 1521, 1526-27 (1982). 
tion's assets. ${ }^{33}$ This paradigm contract, in effect, interprets the basic debtor-creditor exchange to exclude incidents of corporate ownership.

This contractual conception of creditor participation still determines the basic models of corporate law, tax law, and accounting. Thus, today's stockholders elect boards of directors and take the benefit of corporate law's directive that managers enhance "corporate profit and stockholder gain." ${ }^{34}$ Together the inanagers and stockholders are the "debtor"- "corporate profit" does not include "creditor gain." Payinents to creditors are a business cost like labor and materials; they generate tax deductions ${ }^{35}$ and reduce earnings for accounting purposes. ${ }^{36}$ In contrast, periodic payments to stockholders come from "corporate profit" and are not treated as costs. ${ }^{37}$

This model of corporate structure, with its origins in the nineteenthcentury conception of an owner-managed firm, rests on an alignment of managers' and stockholders' economic interests. ${ }^{38}$ But in practice, of course, the interests of nonstockholder managers diverge from those of widely dispersed stockholder "owners." To keep managers' actions consistent with stockholders' interests, corporate law imposes fiduciary duties on inanagers. Creditors, limited to contractual participation, are not beneficiaries of these duties. Traditional notions of debtor-creditor adversity, as well as the structure of risk allocation ainong corporate claimants, justify this treatment. Creditors' and stockholders' interests conflict in investment decisions; stockholders prefer nore risk than do credi-

33. Corporate Debt financing Project, Am. Bar Found., Commentaries on Model Debenture Indenture Provisions 1-2 (1971) [hereinafter ABF Commentaries].

34. Principles of Corporate Governance: ANalysis and Recommendations $\$ 2.01$ (Tent. Draft No. 2, 1984) [hereinafter RESTATEMENT OF CoRporations].

35. I.R.C. $\S 163$ (a) (West 1988). Apparently, this tax treatment is so intuitively appealing that Congress has never bothered to explain it. Comment, Hybrid Instruments and the Debt-Equity Distinction in Corporate Taxation, 52 U. CH1. L. REv. 118, 122 n.23 (1985). For a case offering an explanation, see Commissioner v. O.P.P. Holding Corp., 76 F.2d 11, 12-13 (2d Cir. 1935).

36. But cf. Anthony, Accounting Rates of Return: Note, AM. EcoN. REv., Mar. 1986, at 245 ("[A]ccountants do not rocognize [the cost of the use of equity capital] in calculating a company's income.").

37. These regimes, while committed to the idea that debt and equity are essentially different, are less than successful in distinguishing them at the margin. Convertible bonds and other hybrid instruments present particularly intractable problems for the tax system. One commentator identified 38 factors that courts have considered in classifying interests as debt or equity. See Holzman, The Interest-Dividend Guidelines, 47 TAXES 4 (1969). An attempt to fornulate clear-cut regulations under congressional mandate, see I.R.C. $\$ 385$, ended in failure. See Comment, supra note 35, at 118-19. The accounting profession has had more success with its bright-line rules. See, e.g., EARNINGS PER SHARE, Accounting Practices Bd. Op. No. 15, §§ 15, 31 (1969) (convertible bonds treated as equity for purposes of earnings reports).

38. B. Manning, Legal Capital 12 (2d ed. 1981). 
tors. ${ }^{39}$ As a result, management cannot look to the interests of both; its legal duties extend only to the more vulnerable group, the stockholders. ${ }^{40}$ Corporate legal theory, once again invoking "contract," and echoing the traditional conception, remits creditors to self-protection regarding a firm's investment decisions. This treatment extends to related interests as well. ${ }^{41}$ In practice, corporate creditors accept the directive and respond with an array of contract protections. For example, they employ the ancient device of the hen on debtor property. They also impose covenants not to imjure the creditors' interests. ${ }^{42}$

39. Jensen \& Meckling, Theory of the Firm: Managerial Behavior, Agency Costs and Ownership Structure, 3 J. Fin. ECON. 305, 334-35 (1976).

40. See Restatement of CoRporations, supra note $34, \S 5.04$ n.12 (Tent. Draft No. 5 , 1986); R. CLARK, CORPORATE LAW 17-18 (1986) (managers have duty to maximize shares' value). The ALI remits creditors to the laws of creditors' rights and bankruptcy and to contract-based protection. Following this reasoning, the ALI also denies creditors derivative standing, subject to an exception for convertible bondholders whose interests fairly and adequately represent those of a corporation's equityholders. RESTATEMENT OF CORPORATIONS, supra note $34, \$ 7.02$ comment b (Tent. Draft No. 1, 1982).

41. For example, creditors have a related, similarly risk-averse interest in the maintenance of a substantial block of corporate assets unencumbered by prior or competing claims. See B. MANNING, supra note 38, at 6-7 (discussing creditors' interests in traditional terms).

42. These "business covenants" constrain, inter alia, management discretion to incur additional debt, to encumber property, and to inake distributions to stockholders. For further discussion, see infra notes 55-58 and accompanying text.

None of the incidents of the corporate debtor-creditor model, it bears noting, are absolute. Parties can vary many of them by contract, at least in theory. For example, a guaranty can negate stockholders' limited liability. Creditors may contract for unnsnal powers-indeed, in Delaware they may obtain formal voting rights. DEL. CODE ANN. tit. 8, § 221 (Supp. 1988). Even residnal risk-bearing can be modified by contract. Corporatc law requires the disbursement of the proceeds of the winding up of a business. But the law also respects creditors' subordination agreements among creditors, which modify the distribution of such proceeds. Theoretically, creditors could even contract to remit all or part of such proceeds to the stockholders.

In effect, then, the law's debtor-creditor model fits the characterization used in the law and conomics literature: it provides "off-the-rack" contract terms-nonmandatory provisions available to producing parties at low cost, but subject to variation. See Baird \& Jackson, supra note 28, at 835-36 n.21. Little follows froin this particular insight into the "contractual" nature of the corporation, however. The law contains disincentives that deter parties from exploring contractual alternatives to the received debtor-creditor model. Creditors can share in control in theory, but in practice they do not, because the law does not give them the privilege of limited liability. If they assume control, they assume personal hability for any mismanagement and injury that they inflict in the conduct of business. See Bartlett \& Lapatin, The Status of a Creditor as a "Controlling Person," 28 MERCER L. Rev. 639, 662 (1977) (putting question of "control" at crux of debt-equity risk-return relationship-whether creditor abandons customary role of obtaining security for payinent and attempts to reap direct benefit from corporation's investments); see also Douglas-Hamilton, Creditor Liabilities Resulting from Improper Interference with the Management of a Financially Troubled Debtor, 31 Bus. LAw. 343, 365 (1975) (to avoid potential hability, creditors should exercise extreme care in controlling debtors); Lundgren, Liability of a Creditor in a Control Relationship with its Debtor, 67 MARQ. L. REV. 523, 523-25 (1984) (when creditor exercises substantial control (as ineasured by different tests) over debtor's business affairs, creditor becomes potentially tiable for the debtor's debts). There is no completely effective way to avoid this segment of the inodel. Creditor 
2. Creditor-Protective Supplements. The doctrinal combination of the debtor-creditor mediation and creditors' contractual status makes legal intervention to benefit creditor interests a very unlikely proposition, outside of bankruptcy. But, for two reasons, the law does not absolutely exclude pre-insolvency protection for creditors.

First, there is historical precedent for creditor protection. Corporate law limited creditor protection only after extensive experimentation. In the standard telling, this is a story of failure; it shows that positive law providing pre-insolvency creditor protection cannot work. ${ }^{43}$ The following retelling of the story highlights a different aspect. It connects the "failure" of legal protection for creditors to the appearance of the management corporation around the turn of this century. Creditor protection declined, at least in part, because management corporations made it seem less needed. Management corporations offered better creditor protection in practice. Second, norms of creditor protection contimue to hold a place in corporate law, albeit a subsidiary one. Corporate law, closely inspected, does not sanction unfettered risk taking by managers. The test for legal intervention in a debtor's affairs, "imsolvency or near insolvency," reflects the law's equivocation. ${ }^{44}$ A fairness ethic supports this hesitant recognition of creditors' interests.

a. The rise and fall of creditor protection in corporate law. Creditor protection came into corporate law im the mid-nineteenth century with the first general corporation laws. These laws limited stockholders' hability as a usual consequence of incorporation. ${ }^{45}$ At the same time, they imposed the creditor-protective provisions now known as the legal capital rules. These provided for minimum capital, required that stockholders pay for stock issued, and constrained dividends and other distributions of capital to stockholders. Like limited liability, these rules were a fundamental part of corporate structure; they made creditor protection an intrinsic aspect of corporateness. ${ }^{46}$

Iromically, the legal capital rules allayed individualist suspicions of corporations. Mid-nineteenth century corporations produeed and transacted where only individuals had acted before. This change disturbed

distance from governance-a central incident of the off-the-rack debtor-creditor model-must be built into any rational corporate structure.

43. See B. Manning, supra note 38 , at $84-90$.

44. See supra note 24 and accompanying text.

45. During the time of the special charter incorporation, corporate status did not inevitably imply limited liability, and charters did not contain creditor-protective provisions. See J. HURST, THE LEgTtIMACY OF THE BUSINESS CORPORATION IN THE LAW OF THE UNITED STATES, 17801970 , at 51 (1970).

46. See id. at 27-28, $51-52$ (legal capital rules offset limited hability). 
many people, who charged that corporations subverted the market's check on private economic power, as separate economic entities, they dispersed individual moral and legal responsibility among groups of businessmen. ${ }^{47}$ The new corporation laws addressed these individualist concerns. These statutes contained numerous restraints against corporate and managerial power, ${ }^{48}$ including the legal capital rules.

The judicial doctrine of disregarding the corporate fiction also appeared during this period ${ }^{49}$ and stemmed from the same pattern of response. Under the doctrine of limited liability, the law treats borrowing corporations as separate entities, easily analogized to borrowing individuals..$^{\text {so }}$ But the residuum of individualist suspicion against corporations prompted the courts to make an exception to the rule: limited liability would apply only so long as a corporation conducted its business according to the requirements of the legal model. Formal integrity had to be maintained; viewed objectively, the corporation had to act as a separate person. If the corporation did not do so, the law would revert to the general rule of individual responsibility and lold the corporation's stockholders responsible for its debts.

Management corporations-large corporatious performing inultiple tasks of production and marketing under the control of hierarchies of managers-appeared around 1890 . They rapidly came to dominate the American economy. Corporate law supported thein, and, in so doing, changed. The "liberal incorporation" statutes of the early twentietl century offered standardized corporate structures without imposing ancillary regulation of business decisions. ${ }^{51}$ This support for management came at the expense of outside investors - both stockholders and creditors. The legal capital rules, not notably effective in the first place, were diluted.52

The dilution of the legal capital rules brought the corporate debtorcreditor model into conformity with the model from noncorporate

47. See Bratton, Historical Perspectives, supra note 29.

48. Id.

49. See Central Trust Co. v. Bridges, 57 F. 753, 766 (6th Cir. 1893), modified sub. nom. Central Trust Co. v. Condon, 67 F. 84 (6th Cir. 1895); Atchison, T. \& S.F.R.R. v. Davis, 34 Kan. 209, 210,8 P. 530, 531 (1885); Blumberg, Limited Liability and Corporate Groups, 11 J. CoRP. L. 573, 594, 60911 (1986); Wormser, Piercing the Veil of Corporate Entity, 12 ColuM. L. REv. 496, 498-506 (1912) (discussing late 18th- and early 19th-century cases that looked beyond corporate fiction).

50. For this reason, corporate law's adoption of debtor-creditor doctrine designed for individual borrowers has never presented great conceptual problems. See also supra notes 23-28 and accompanying text (discussing debtor-creditor law in corporate context).

51. See Bratton, Historical Perspectives, supra note 29.

52. The incorporation statutes authorized low-par and no-par common stock, permitted minimal paid-in capital and later reductions of capital, and dropped requirements for minimuin debtequity ratios. See J. HuRsT, supra note 45 , at 53 . 
debtor-creditor law for the first time. Corporate law continued to offer a series of creditor-protective provisions. In practice, however, these protections apphed only to gross abuse-debtor actions at or near insolvency. ${ }^{53}$

Those with the most to lose, long-term creditors of management corporations, took the changes in stride. Creditors' relations with the new inanageinent corporations took on a new dynamic. The new managers were less likely to act in derogation of creditors' interests than were the entrepreneurial owner-managers of the smaller corporations of the preceding period. To creditors' comfort, the new managers took a longterm, institutional view; they eschewed short-term gambles for investinent with an eye to continuity. ${ }^{54}$ At the same time, creditors developed new inodes of contractual self-protection. The debenture indenture, the contract vehicle that facilitated public sales of the new corporations' unsecured debt, appeared around 1900, just as states began diluting the legal capital rules. This device solved problems of enforcement and monitoring by widely dispersed debtholders. It also introduced the business covenant as a more flexible security device than the real property inortgage. $^{55}$

Thus, corporate law dispensed with most creditor protections only after the turn of the century. Corporate doctrine thereafter gradually evolved toward the traditional debtor-creditor standard of nonintervention. But the change did not follow from soine sudden theoretieal recognition of a strict analogy between corporate and individual debtorcreditor relationships. Nor did it follow from soine surge of theoretical contractualism. ${ }^{56}$ Rather, nonintervention followed from relational practices that evolved with the new inanagement corporations. Large, perinanent-looking producing institutions emerged as borrowers. Their creditors had well-founded expectations of the borrowers' institutional

53. Id.

54. Id. at 54-55.

55. Garrett, $A$ Borrower's View of the Model Corporate Debenture Indenture Provisions, 21 Bus. LAw. 675, 678-80 (1966). The amount of money outstanding in corporate debentures grew enormously during the decades after 1900 . Before the indenture appeared, a debenture stated holders' rights directly on the note; this practice led to problems of enforcement and momitoring. The indenture solved the problem by channeling perfonnance rights through a trustee for the benefit of the holders of a debenture. Id. at 678.

Mortgage indentures, in contrast, first appeared during early American corporate history. They were invented in the 1830 s to facilitate the debt financing of the great capital projects of the daycanals, railroads, and turnpikes. See Banks, Indenture Securities and the Barkley Bill, 48 Y ALE L.J. 533, 534 (1939).

56. On the contrary, of all decades in the history of corporate doctrine, the first decades of the twentieth century showed the least focus on contract ideas. See Bratton, Historical Perspectives, supra note 29. 
stability. Moreover, those who controlled these borrowing institutions had common interests with their long-term creditors. As a result, longterm unsecured lending made sense for the first time. As creditors abandoned the ancient requirement of a tangible security, contract became feasible as the sole basis for long-term corporate debt. Debt became "contractual" in legal theory in the wake of these practical developments. This recognition conveniently served managenient's interests. Creditors, meanwhile, evolved into passive investors holding strictly delimited rights and presenting no threat to inanagement control.57

Although corporate debt became contractual, it was not always exclusively so. And it need not always remain so. If the institutional situation that gave rise to this theoretical approach should change substantially, the theory can be reconsidered. Arguably, such changes have occurred in recent years. The corporate restructuring movenient has destabilized management's institutional position, to the detriment of unsecured creditors. At the same time, it has lessened corporate law's managerialist bias. 58

b. Norms of creditor protection in corporate doctrine-equivocation in the traditional conception. Pohicy debates on the appropriateness of legal intervention in corporate debtor-creditor relationships continue today, despite the apparently settled state of the doctrine. Different views on the desirability of managenent risk taking animate these diseussions.

Under one line of thinking, risk can be a bad thing, and managers should be discouraged from taking on too inuch of it. Obviously, in an uncertain world, investing entails risk. Undertaking this risk is generally desirable, as long as an investing manager brings care and dehberation to the task. Speculation is a different, less prudent and more questionable endeavor. ${ }^{59}$ It lacks a legitimating tie to the work ethic. The speculator seeks to get sonething for nothing, like a gambler.

This antispeculative thinking bears on corporate debtor-creditor policy; given limited liability, the owner of a heavily indebted corporation is particularly likely to make speculative investments. Such investments have substantial upside potential, and creditors bear the risk of

57. Fitting stockholders into the practical mold of the passive investor has proved a tougher proposition. Characterized as the problem of the "separation of ownership and control," it has created all sorts of conceptual problems for corporate law in this century, given the persistence of the old property model of stock ownership. See id.

58. The change's implications are discussed infra notes 186-345 and accompanying text.

59. See B. Graham, D. Dodd \& S. CotTle, Security Analysis: Principles and TechNIQUES 47-58 (1962) ("prudent conduct require[s] that purchases of common stocks at prices that rely heavily on future developments to jnstify the commitment be rccognized as at least partially speculative in their nature"). 
failure. An antispeculative observer would argue that the lack of creditor protection in law encourages such inefficient, excessively risky investments. This observer would also argue that debtor protection in the form of corporate limited hability invites the commission of business torts. This possibility forces creditors to allocate resources to research and inowitoring-expenditures ultimately passed on in the form of higher prices. ${ }^{60}$

An opposing line of thinking defends risk, even in large doses, drawing on the assumptions of neoclassical microeconomics. ${ }^{61}$ Risk is a good thing-production, after all, is intrinsically risky. Furtherinore, given rational parties and competition, prices in contracts, including debt contracts, reflect the risks assumed. ${ }^{62}$ We can justify legal intervention only if it reduces costs, that is, only if most parties would contract for the provision in question anyway. ${ }^{63}$ Accordingly, legal intervention to protect a contract creditor is rarely justified. A creditor's consent to a transaction vitiates the business tort described in the antispeculative argument. 64 In addition, creditor protection in law would chill inanagement risk taking. ${ }^{65}$

Both lines of thinking influence contemporary corporate debtorcreditor doctrine. This doctrine includes the remains of the ninetecnthcentury legal capital rules, fraudulent conveyance law, the judicial doctrine of disregarding the corporate fiction, and the equitable subordination provisions of bankruptcy law. ${ }^{66}$ This bundle of provisions instantiates the conflict over management risk taking. The doctrine accords recognition to antispeculative values and nakes a number of ges-

60. See Conard, Theses for a Corporate Reformation, 19 U.C. DAvis L. REv. 259, 269.71 (1986). For a thought-provoking variation on this argument, see Halpern, Trebilcock \& Turnbull, An Economic Analysis of Limited Liability in Corporation Law, 30 U. ToRonro L.J. 117 (1980). Halpern, Trebilcock, and Turnbull take the position that limited liability permits stockholders to make uncompensated transfers of business risks to creditors, and thus creates incentives for firms to allocate excessive resources to risky investments. They find that limited liability is efficient only in the case of management corporations. Limited liability facilitates the trading of management corporations' equity securities by preventing costly uncertainties in valuation. In close corporations, however, it creates a moral hazard and leads to costly attempts to avert risk. Id. at 126, 147-48.

61. For a discussion of these assumptions, see infra notes $132-33$ and accompanying text.

62. Eg., Easterbrook \& Fischel, Limited Liability and the Corporation, 52 U. CHI. L. REv. 89, 94 (1985) (limited liability reduces cost of separating management and capital).

63. See Baird \& Jackson, supra note 28, at 834-36 (discussing fraudulent conveyance law).

64. See Carlson, Is Fraudulent Conveyance Law Efficient?, 9 CARDozo L. REv. 643, 648-49, 675-76 (1987).

65. See Baird \& Jackson, supra note 28 , at 839 (arguing against expansive application of fraudulent conveyance laws).

66. For a comparative study of these legal regimes, see Clark, The Duties of the Corporate Debtor to its Creditors, 90 HARv. L. REv. 505 (1977). 
tures in the direction of creditor protection. But, recognizing the opposing point of view as well, it keeps these gestures ineffective.

The doctrine's creditor-protective gestures tend to concern the conduct of inadequately capitalized debtors. Section 5 of the Uniform Fraudulent Conveyance Act contains the primcipal constraint. ${ }^{67}$ This fraudulent conveyance rule not only prohibits transactions of an insolvent debtor and transactions that cause insolvency, 68 but also transactions that leave an operating debtor with unreasonably small capital. Restated, section 5 conditions the validity of transfers for inadequate consideration on adequate capitalization. It has been apphed only rarely, however, and commentators attach hittle importance to it. ${ }^{69}$ Inadequate capitalization also justifies piercing the corporate veil in favor of involuntary creditors in soine cases. ${ }^{70}$ In addition, concern over inadequate capitalization informs equitable subordination rules in bankruptcy that prevent recognition of controlling stockholders' debt claims. ${ }^{71}$

A body of caselaw gives these provisions rhetorical support. The cases use fiduciary language to condemn fraudulent conveyances by corporate owners. The usage can be traced back to 1824, when, in Wood $v$. Dummer, Justice Story described the corporate capital protected against fraudulent conveyances as a "trust fund."72 This language was often cited thereafter, despite the fact that Wood involved neither a "trust" nor a "fund";73 it survived as a creditor-protective metaphor. Justice Douglas reinforced this rhetorical tradition in the 1939 case Pepper v. Litton, explaining the Court's avoidance of another garden-variety fraudulent conveyance in terms of a fiduciary duty to creditors. ${ }^{74}$

67. Untf. Fraudulent Conveyance ACt § 5, 7A U.L.A. 504 (1985); see also Unif. FraUdulENT TRANSFER ACT § 4, 7A U.L.A. 652-53 (1985).

68. UNIF. Fraudulent Conveyance ACt $\$ 4,7 A$ U.L.A. at 474; see also id. § 7, 7A U.L.A. at 509 (prohibiting conveyances made with intent to hinder, delay, or defraud creditors).

69. See, eg. Note, Fraudulent Conpeyance Low and Leveraged Buyouts, 87 ColUM. L. REV. 1491, 1508 (1987). Clark explains section 5 as an assurance that technical insolvency provisions do not vitiate the purpose of the broader prohibition on fraudulent conveyances. Clark, supra note 66 , at 545.

70. See Clark, supra note 66, at 547. The leading case is Minton v. Cavaney, 56 Cal. 2d 576, 579, 364 P.2d 473, 475, 15 Cal. Rptr. 641, 643 (1961) (en banc).

71. See, eg., Amold v. Phillips, 117 F.2d 497, 501-02 (5th Cir.), cert denied, 313 U.S. 583 (1941) (level of capitalization of firm showed that advances received by controlling creditor constituted loans, not new creditor capital); see also Clark, supra note 66, at 534-35 (thin capitalization, while not necescarily a sole and sufficient basis for subordination of stockholders' claims, often accompanies such subordination).

72. 30 F. Cas 435, 436 (C.C.D. Me 1824) (No. 17,944) (involving transfer of assets to stockholders, made at point of insolvency).

73. B. Manning, supra note 38 , at 46.

74. 308 U.S. 295, 310-12 (1939). Among the subsequent cases applying these fiduciary principles are Brown v. Presbyterian Ministers Fund, 484 F.2d 998, 1005 (3d Cir. 1973); Bayliss v. Rood, 424 F.2d 142, 146 (4th Cir. 1970). 
Outside of this fragmentary group of cases and statutes, the law mediates corporate debtors' and creditors' interests by hewing to the insolvency line. The provisions just described support the integrity of promises to repay against debtors' abusive conduct, but stop short of supporting creditors' interests with affirmative duties of management cooperation. ${ }^{75}$ Yet no intrinsic, technical barriers make the imposition of such duties impracticable. Corporate law could protect creditors by regulating manageinent risk taking. Presumably, such regulation would impose minimum capital requirements that would ensure a substantial asset cushion above a corporation's total habilities. ${ }^{76}$ For the regulation to have tecth, it would have to constrain management's discretion to finance, invest, and distribute assets once the danger line was reached. ${ }^{77}$ The absence of such a regime affirms the risk-favorable line of thinking.

But we should not dismiss this persistent, hesitant, and ineffective pattern of legal creditor protection as historical detritus. ${ }^{78}$ As long as we avoid a narrow instrumentalist perspective, the pattern can be explained and justified: it persists in order to withhold full legitimation of risk taking. Section 5 of the Uniform Fraudulent Conveyance Act, the legal capital rules, and the rhetoric of the cases together establish that the law may censure debtor conduct that occurs before insolvency. The underlying norin asserts that when insolvency is a real possibility, debtor con-

75. See Clark, supra note 66 , at 547. Clark, reviewing the veil-piercing and equitable subordination cases, suggests that they reflect judicial experimentation with a new duty of cooperation. Events since the publication of Clark's article suggest that we can expect little furtluer experimenta. tion of this sort. See infra notes 269-88 and accompanying text.

Corporate debtor-creditor law continues to uphold the moral ideals Clark identifled-truthfulness, respect (a moral duty to give.legal obligations primacy over one's self-interest), evenhandedness among creditors, and nonhindrance of satisfaction of creditors' claims. Id. at 509-13. Carlson's exposition of the values underlying fraudulent conveyance law resembles Clark's. Carlson emphnsizes the norm of keeping promises, the work ethic, and the norm against intentionally inflicting harm. Carlson, supra note 64, at 672-74.

76. Cahfornia, for example, requires an assets-to-liabilities ratio of 1.25 to 1. CAL. CORP. CODE $\S 500$ (b) (West Supp. 1989). A state might also require interest coverage providing a cushion above equity insolvency.

77. Clark suggests that, at a minimum, the law should forbid dividends at this point, and that it slould forbid new indebtedness absent an affirmative slowing that such indebtedness would improve the situation of the company at issue. For still more effective protection, lie suggests a requirement that a company in danger of insolvency, raise new equity capital. This suggestion, however, would conflict with the policy favoring limited liabilty. Clark, supra note 66, at 559-60. Clark suggests using a concrete ratio test to set the "danger line" Id.; see also Keustermans, Countertrends in Financial Provisions for the Protection of Corporate Creditors: The Model Business Corporation Act and the E.E.C. Corporate Directives, 14 DEN. J. INT'L L. \& POL. 275, 298 (1986) (both U.S. and E.E.C. corporate law would benefit from a meaningful financial ratio test). For the alternate view, see Conard, supra note 60 , at 288-89 (advocating a reasonableness standard set with reference to capitalization patterns in each industrial group).

78. The provisions have been fairly attacked for "analytic naivete and want of policy content." B. MANNing, supra note 38 , at $x$. 
duct that injures creditors has no legal sanction. The provisions still lack "teeth"-effective enforcement provisions benefiting creditors. They do not provide an effective means to a concretely conceived end. But they at least take some conduct out of the zone of free contract, where the law imphicitly sanctions self-interested conduct. At certain legal margins, this refusal can determine an outcome. And the survival of these rules 79 confirms the general acceptance of the underlying norm. ${ }^{80}$

\section{Corporate Debt as Investment: The Realist Revision}

1. Economics and History. According to an old financial maxim, borrow $\$ 1000$ and you have a banker; borrow $\$ 1,000,000$ and you have a partner. ${ }^{81}$ The maxim challenges the traditional conception's fundamental economic assumption, a clear distinction between debt and equity. Under that assumption, debt's basis in a promise to pay makes it materially different from equity, with its exposure to the highest risk of loss. The maxim, in contrast, asserts that debt and equity are not so easily distingrished, at least with a large, long-term loan. This assertion underhes the "imvestinent" conception.

The investinent conception emphasizes the shared characteristics of debt and equity-debt and equity investinents differ only in degree; they are not fundamentally different forms of participation. ${ }^{82}$ Like equity imvestors, debt investors have their funds tied up in the fortunes of the

79. The legal capital rules, with their analytically naive formalities, symbolically impress the norm on persons doing business in the coprorate form. Id. at 88-89. They thus can be justified in the categories that Fuller and von Mehren described for legal formalities. A formality "channels" beluavior by signaling an actor's awareness that certain conduct may have legal significance, and it deters by making suspect transactions harder to complete. See Fuller, Consideration and Form, 41 Colum. L. REv. 799, $801-03$ (1941); von Mehren, Civil-Law Analogues to Consideration: An Exercise in Comparative Analysis, 72 HARv. L. REv. 1009, 1016-17 (1959). More broadly, the provisions withhold legal sanction from loosely defined patterns of behavior.

Their failure to satisfy instrumentalist policy scrutiny does not justify their removal. Interest"ingly, just such arguments underlie a recent reform of the Model Business Corporation Act's legal capital provisions. The new provisions in effect make the insolvency line the sole corporate debtorcreditor provision, yet the drafters justify the new provisions in terms of creditor protection. They argue that the current legal capital rules provide no concrete protection and may mislead securitylholders who rely on them. ABA Comm. on Corporate Laws, Changes in the Model Business Corporation Act-Amendments to Financial Provisions, 34 Bus. LAw. 1867, 1867-69 (1979). The problem is that, by retreating to the insolvency line, the reformed provisions make the pre-insolvency gray area part of the zone of free contracting. This change poses significant larm to creditors. For an instrumentalist attack on the reform suggestions, see Keustermans, supra note 77, at 292-93.

80. B. MANNING, supra note 38 , at 89 (provisions may psychologically inhibit corporate management from distributing assets indiscriminately). Manning recognizes the historical, cultural, and psycliological powers of the legal capital provisions even as he joins in the inovement for their abolition. Id. at 164-67.

81. R. Brealey \& S. Myers, Principles of Corporate Finance 395 (2d ed. 1984).

82. Frank, Book Review, 42 YALE L.J. 989, 992-93 (1933) (reviewing A. BERLE \& G. MEANS, The Modern Corporation and Private Property (1932)); see also Llewellyn, What Price 
enterprise. ${ }^{83}$ Like equity, debt can be dispersed among widespread small holders. Debtholders thus join equityholders as outsiders dependent on effective performance by corporate managers, a separate interest group without substantial security holdings. Given these characteristics, even notions of common enterprise and norms of cooperation may appropriately describe debt-equity relationships.

The investment conception sprang from historical experience. Beginning with mid-nineteenth-century railroad bonds, and extending to all debt of management corporations after the turn of the century, payment defaults no longer resulted in direct enforcement of promises to repay. Tearing up a railroad and selling it made no economic sense. ${ }^{84}$ To preserve going concerns, payment difficulties had to be "worked out." A reinterpretation of the debt exchange resulted. A promise to repay could no longer be taken hiterally. A creditor looked for repayment less to the promise than to the continuing vitality of the promisor's enterprise. ${ }^{85} \mathrm{~A}$ promise to pay, in reality, amounted to a promise to "refund" if the enterprise succeeded, and a basis for priority over equityholders if the enterprise failed. ${ }^{86}$ The promise did operate literally upon hquidation-but large modern corporations are rarely liquidated, even in bankruptcy. Thus linked to the business's fortunes, creditors becoine investors.

Academic writing on the investment conception first appeared in the early part of this century. Alfred Dewing, who wrote the period's leading business treatise, advocated it. ${ }^{87}$ Legal realists, including Berle, ${ }^{88}$ Frank, ${ }^{89}$ Llewellyn, ${ }^{90}$ and Douglas, ${ }^{91}$ introduced it to corporate law. These writers predicted that the new concept would come to dominate the law.

Contract? -An Essay in Perspective, 40 YAlE L.J. 704, 724 (1931) (debt contract ensures either performance or ratable share in bankruptcy).

83. 1 A. DEWING, supra note 25 , at $166-67$.

84. Id. at 236-37.

85. See, eg., J. HURST, supra note 45, at 54; B. MANNING, supra note 38, at 14.

86. 1 A. DEWING, supra note 25, at 236-37. As Jerome Frank cynically put it, this "priority" translates to an undertaking by creditors to accept new securities at the option of those in control in the event of financial embarrassment and a corporate reorganization. Frank, supra note 82, at 992.

87. See 1 A. DEwing, supra note 25, at 166-67, 236-37. Citing an omnipresent "more realistic attitude," Dewing predicted that bondholders would receive certain management rights. Id. at 16667. The basic economic point that stockholders, bearing the residual risk, have the incentive to raise profits and therefore should control, rebuts Dewing's argument. See McDaniel, Bondholders I, supre note 10, at $440-41$.

88. See A. BERLE, supra note 28 , at 156 . Berle predicted that pursuit of a rule of management duty to the "general" interest of "investors" would result in corporate creditors receiving judicial protection beyond the strict letter of their contracts. Id.

89. See Frank, Some Realistic Reflections on Some Aspects of Corporate Reorganization, 19 VA.

L. REv. 541, 566-67 (1933); Frank, supra note 82, at 992-93.

90. See Llewellyn, supra note 82, at 724.

91. See W. Douglas, Democracy and Finance 177.78 (1940). 
2. The Investment Conception and Corporate Legal Theory. Advocates of the investment conception look past traditional corporate doctrine to business practice. They describe a variable, tripartite relationship among debtholders, equityholders, and management.92 They focus on management power and work to control it in law, considering the constituent relationships in the corporation's financial structure against the background of management power, one by one. ${ }^{93}$ The classical stockholder-entrepreneur has disappeared, and the creditor no longer appears as a refined and hostile opponent. More likely than not, the creditor is a bondholder - a single investor holding a piece of paper that gives no practical means of achieving corporate power.

In this conception, creditors are aligned with stockholders in the antimanagerialist vision of corporate power relatiouships. Both occupy a position resembling that of the weak party in a trust relatiouship; the managers possess the power. ${ }^{94}$ Carried to its logical conclusion, the conception questions why corporate law directs management fiduciary duties to equity interests only. ${ }^{95}$ Creditor protection in law follows as a practical possibility and a pohicy priority.

\section{The Traditional and Investment Conceptions as Competing Influences on the Development of Corporate Law}

The investment conception has influenced the development of corporate law, but it has never achieved the permanent ascendancy predicted by its realist advocates. Instead, corporate law has held to its basis in the traditional conception, relegating the investment conception and its creditor-protective norm to a supplemental position.

1. Depression-Era Reforms The investment conception heavily influenced the statutory reforms of the Depression era-the bankruptcy acts of $1933^{96}$ and $1938^{97}$ and the federal securities laws. ${ }^{98}$ The bankruptcy reforms admitted bondholders to corporatc ownership, treating

92. Berle introduced this concept in 1928. See A. BERLE, supra note 28, at 181-94.

93. See, eg., id.

94. In Berle's words, both creditors and stockholders depend on management"s "fidelity and business integrity." Id. at 156.

95. See, e.g., Conard, supra note 60 , at 276-78.

96. Bankruptcy Act of 1933, ch. 204, 47 Stat. 1467 (revised 1938).

97. Bankruptcy Act of 1938, ch. 575, 52 Stat. 840 (repealed 1978).

98. Eg. Securities Exchange Act of 1934, ch. 404,48 Stat. 881 (codified as amended at 15 U.S.C. $\$ \S 78 \mathrm{a}-78 \mathrm{kk}$ (1982)); Securities Act of 1933 , ch. 38,48 Stat. 74 (codified as amended at 15 U.S.C. $\$ \$ 77 a-77 a a)$. 
thein as joint owners with a prior claim against corporate assets. 99 To limit management power for the benefit of all interested parties, creditors and workers as well as stockholders, these laws provided for administrative evaluation and judicial approval of reorganization plans. The federal securities laws, in turn, protected all securityholders, whether of debt or equity. ${ }^{100}$ With the Trust Indenture Act of 1939,101 even the standard debt contract underwent reform. Antimanagerialists charged that managers and investment bankers dominated workouts and reorganizations, recapitalizing compaines at the expense of small bondholders. ${ }^{102}$ The Trust Indenture Act responded by mandating that debt contracts governing publicly issued bonds include certain procedural protections, most notably a prohibition against less-than-unanimous waivers of important contract rights. ${ }^{103}$

These federal reforms, while substantial, did not dislodge the traditional conception from its central position in corporate law. ${ }^{104}$ Although the federal securities laws protected small investors by imposing new rules to govern investment processes, ${ }^{105}$ they otherwise accepted the received doctrinal model of corporate organization. Although the bankruptcy acts moved creditor protection to the forefront of the law, they followed and complemented the traditional debtor-creditor mediation. ${ }^{106}$ The Trust Indenture Act, the only reform designed to introduce creditorprotective duties in the pre-insolvency workout stage, did so by employing mandatory contract provisions, a legislative technique designed to avoid disruption of the underlying contractual regime. Thus, corporate debt relationships remained contractual even as they became heavily regulated.

99. 1 A. DEWING, supra note 25 , at $237 \&$ n.72. The Public Utility Holding Company Act of 1935, ch. 687, secs. 6-7, 49 Stat. 803, 814-17 (codified at 15 U.S.C. $\$ \S 79 f-79 \mathrm{~g}$ ), under which most of the country's utilities were recapitalized, also gave creditors a protected position.

100. See, 15 U.S.C. $\$ \$ 77 b(1), 78 c(a)(10)$ (defining "security" to include, inter alia, bonds, debentures, and evidence of indebtedness).

101. Ch. 411,53 Stat. 1149 (codified at 15 U.S.C. $\$ \$ 77 a a a-77 b b b b)$.

102. Commentators rebutted this allegation at the time. Defenders of management said that the instances of abuse were exaggerated and that the corporate trust system was working better than at any earlier point in its century-long history. See Banks, supra note 55, at $539-43$ (corporate trust indenture does not provide complete escape from responsibility and works with unusual success).

103. See 15 U.S.C. $\$ \S 77 \mathrm{aaa}-77 b b b b ;$ see also Roe, The Voting Prohibition in Bond Workouts, 97 YALE L.J. 232, 250-69 (1987) (summarizing policy reasons for prolibition against waivers of important contract rights upon less than unanimous bondholder consent and discussing why those policy reasons are no longer relevant).

104. They have, lowwever, loosened the traditional conception's bold. See Bratton, Convertible Bonds, supra note 10, at 734.

105. See J. HURST, supra note 45 , at 55 .

106. That is, they inposed intensive creditor protection only after insolvency and the commencement of receivership. 


\section{Patterns from 1945 to 1980.}

a. Legal practice Postwar prosperity and stability fostered peaceful coexistence between the traditional and investment conceptions, at least in the world of law practice. Practitioners blended the two conceptions. 107 Debt contracting, while remaining adversarial, no longer seemed to fit perfectly into the classical framework of hard bargaining between parties at arm's length. The best practice, taking cognizance of the nature of the debt relationship, balanced adversity and cooperation. ${ }^{108}$ Under the influence of the investment conception, practitioners used the tools of law reform to improve the debt contracting process by institutionalizing this balanced approach. The organized corporate bar drafted not one, but two inodel debenture indentures, ${ }^{109}$ which amounted to inodel governance statutes. They echoed the Berlian corporate inodel, looking toward consensus provisions that would satisfy the competing interests of all parties in corporate financings-bondholders, borrowers, lending institutions, investment bankers, and corporate trustees. 110

As adversity waned, bondholders also demanded less security. With the largest, inost stable corporate borrowers, contract protections, even those following inodel forms, began to disappear from practice. ${ }^{111}$ Given these institutions' strength and their managers' clear interest in continued stability, these protections seeined superfluous. ${ }^{112}$ Thus, bonds, conceived in theory to reseinble stock, began to reseinble it in practice. A bond without covenants, like a share of stock, is an investment made under loose legal guidelines that leave inanagement discretion largely unimpaired.

b. Caselaw. Whereas postwar practice sought to synthesize the traditional and investment conceptions, postwar cases treated the two conceptions as opposites. Courts deciding stockholder-bondholder disputes invariably privilege one conception, and doctrinal approaches follow froin the conception favored.

107. Depression-era memories faded slowly. The Bankruptey Reform Act of 1978 finally removed the more extreme creditor-protective provisions of the 1938 statute. Specifically, it abandoned the absolute priority rule and mandatory SEC inspection of companies' reorganization plans in favor of a more contractual model. See 11 U.S.C. § 1129 (1982 \& Supp. IV 1986).

108. See Garreth, supra note 55, at 682.

109. See ABF Commentaries, supra note 33, at 14; ABA Section of Corp., Banking \& BusiDess Law, Model Simplified Indenture, 38 Bus. LAw. 741 (1983) [hereinafter MSI].

110. See, eg., MSI, supra note 109 , at 742.

111. Indeod, the second model indenture form omitted business covenants entirely. The form's drafters stated that business covenants were left to negotiation. See id. at 743. In contrast, the model indenture put together a decade earlier assumed that business covenants would be included in the ordinary conrse.

112. See infra notes $206-19$ and accompanying text. 
$i$ Fiduciary duties. The traditional conception, with its assertions that debtholders are not a firm's "owners" and that the debtorcreditor relationship is contractual, forecloses imposition of a bondholder-protective fiduciary duty. The investment conception, in contrast, opens fiduciary possibilities by encouraging a situational approach to corporate duties and stressing the characteristics shared by bondholders and the traditional beneficiaries of fiduciary duties, stockholders.

The Delaware courts have been the traditional conception's firmest adherents, becoming quite outspoken im recent years. ${ }^{113}$ In Delaware, bondholder rights follow the debtor-creditor model. The bondholder has contract rights only, except in extreme situations of fraud or insolvency; ${ }^{114}$ beyond the promise to repay and the integrity of that promise, the bondholder has no rights against self-interested issuer conduct. ${ }^{115}$ If

113. The best-known instance of this outspokenness is Revlon, Inc. v. MacAndrews \& Forbes Holdings, Inc., 506 A.2d 173 (Del. 1986), a pivotal takeover case. Revlon, in the course of a defensive exchange offer to its own stockholders, placed debentures containing a restrictive covenant that was waivable by Revlon's independent directors. During a later phase of the takeover contest, the board waived the covenant to facilitate a defensive inerger. Bondholders protested. The board de fended its choice to engage in the defensive transaction partly on the ground that the defensive offeror offered to support the price of the debentures. Id at $180-81$; cf. R. CLARK, supra note 40, at 25 (stating business judgment rule).

The court held the board's creditor-protective rationale impermissible. $506 \mathrm{A.2d}$ at 182 . Because the board had reached the "auction" stage-it was no longer taking action to preserve Revlon as an entity-it was not free to take nonstockholder interests into account.

The opimion blends the usnal consignment of creditors to contractnal protection with a special "auction" limitation on the business judgment rule. Cf. id. at 182-83. The business judgment rule would ordinarily bar serutiny of a board's bondholder-protective decision, as long as the board could show some rational eonnection to stockholder interests. Presumably, the need to maintain good will in the credit markets would afford a sufficiently rational coumection.

114. The leading case is Harf.v. Kerkorian, 324 A.2d 215 (Del. Ch. 1974), rev'd, 347 A.2d 133 (Del. 1975). In Harff, convertible bondholders challenged a large dividend as a breach of fiduciary duty. The Chancellor granted a motion to dismiss on the ground that no fiduciary duty existed, and, in another connection, cited Parkinson v. West End St. Ry., 173 Mass. 446, 53 N.E. 891 (1899) (Holmes, J.), the classic case characterizing convertible bonds as contracts. The Delaware Supreme Court reversed, interpreting the complaint to contain an allegation of fraud. 347 A.2d at 134; see also Wolfensohn v. Madison Fnnd, Inc., 253 A.2d 72, 75 (Del. 1969) (debenture and certificate holders' rights determined exclusively by contract); Simons v. Cogan, 542 A.2d 785 (Del. Ch. 1987) (reaffirming Harff rule), aff'd, 549 A.2d 300 (Del. 1988); Katz v. Oak Indus., 508 A.2d 873 (Del. Ch. 1986) (same).

The Harff court's inplicit asssumption that corporate creditors historically have not benefitted from legal protection is, of course, incorrect. See supra notes 43-50 and accompanying text; see also Stetson, Preparation of Corporate Bonds, Mortgages, Collateral Trusts and Debenture Indentures, in association of the Bar of the City of N.Y., Some Legal Phases of Corporate financING, REORGANIZATION AND REgULATION 25-27 (1917) (justifying complexity of trust indentures, not on ground that no legal protection exists, but on ground that inplied-in-law protection is too uncertain).

115. See Fox v. MGM Grand Hotels, Inc., 137 Cal. App. 3d 524, 528, 187 Cal. Rptr. 141, 143 (1982) (following Delaware approach); see also Kessler v. General Cable Corp., 92 Cal. App. 3d 531, 540, 155 Cal. Rptr. 94, 100 (1979) ("holders of debentures, with an option to convert, remain corporate creditors ouly, without any special status which affords them the opportunity to litigate in the 
the bondholder suffers an injury, it is a risk that he assumed. ${ }^{116}$

The decisions of soine federal appellate courts depart from the traditional conception. These courts pick up the invitation extended by Justice Douglas's Pepper y. Litton ${ }^{117}$ rhetoric, invoking fiduciary principles and applying fairness scrutiny to corporate action that injures bondholders. ${ }^{18}$ But the decisions set out this fiduciary duty very tentatively. Discussion of the source and nature of the duty tends to be fragmentary, and the duty's precise relationship to contract terms is unclear. The duty sometimes overrides contract terms, affording additional protection based on a bondholder's relationship with a corporation. ${ }^{119}$ In most cases, however the duty reinains subject to the contract's terms; it takes a breach of contract to breach the duty. ${ }^{120}$

ii. Contract duties. Stockholder-bondholder disputes also tend to raise contract-law issues, usually in connection with interpretation of debt contracts. Contract law offers a surprisingly wide selection of norms for resolution of these disputes. Here again, a decisionmaker's underlying conception of the relationship-traditional or investmentinfluences doctrinal choice.

Decisionmakers following the traditional conception apply classical contract doctrine-the doctrine recognized by Williston and the first $R e$ statement. Classical doctrine presupposes an adverse and arm's-length relationship: the party asserting a right bears the burden of drafting it into the contract. It also assnmes that contract language has an immutable ineaning: applying the correct interpretive calculus leads to the objectively correct meaning. 121

Decisionmakers who follow the investment conception apply neoclassical contract doctrine-the contract law of Corbin and the Restate-

area of potential damage to their economic interests"); ABF COMMENTARIES, supra note 33, at 1-2 (debtholders' rights largely a matter of contract).

116. See, eg., Harf, 324 A.2d at 219, 222 (debenture holders' rights determined by their contract alone).

117. 308 U.S. 295 (1939); see supra notes $72-74$ and accompanying text.

118. See Pittsburgh Terminal Corp. v. Baltimore \& O.R.R., 680 F.2d 933 (3d Cir.) (Gibbons, J., announcing panel judgment) (implying fiduciary duty to convertible debenture holders), cert. denied, 459 U.S. 1056 (1982); Green v. Hamilton Int'l Corp., 437 F. Supp. 723, $726-28$ (S.D.N.Y. 1977) (convertible debenture holders entitled to Rule $10 \mathrm{~b}-5$ protection).

119. See, eg., Van Gemert v. Boeing Co., 520 F.2d 1373, 1383-84 (2d Cir.) (issuer has duty to give notice of redemption call), cert. denied, 423 U.S. 947 (1975). A later panel of the same court, however, characterized the opinion as based on the contract-law duty of good faith. Van Geinert v. Boeing Co., 553 F.2d 812, 815 (2d Cir. 1977).

120. See, eg., Gardner \& Florence Call Cowles Found. v. Empire Inc., 589 F. Supp. 669 (S.D.N.Y. 1984) (no breach of fiduciary duty unless derived from terms of trust indenture), vacated on other grounds, 754 F.2d 478 (2d Cir. 1985).

121. Bratton, Convertible Bonds, supra note 10, at 692. 
ment (Second). No preconceived drafting burden confines the inquiry to exphicit language. Nor does the investment conception include an assumption that language has an immutable meaning, which would limit interpretive inquiries to standard English usage. Instead, the decisionmaker goes beyond linguistic and structural analysis of a document to consider the parties' entire relationship, seeking the meaning inost consonant with the parties' expectations. Under the rubric of contractual "good faith," decisionmakers bring ethical constraints to bear against self-interested conduct that injures other contract parties. ${ }^{122}$

Not suprisingly, the same courts that refuse to extend a fiduciary duty to bondholders decline to pursue the inore open-ended neoclassical inquiry into a contract's meaning. The traditional conception underlies both results. ${ }^{123}$ Under classical interpretive constraints, bondholder claims that would be entirely plausible under a broader interpretive perspective invariably fail. ${ }^{124} \mathrm{~A}$ smaller group of cases, following the investment conception, abandons classical interpretive restraints and reverses

122. Id. at 684,692 .

123. The leading case, Broad v. Rockwell Int'l Corp., 642 F.2d 929, 959 (5th Cir.) (en banc), cert denied. 454 U.S. 965 (1981), invokes the history and function of trust indentures to justify the application of classical principles: clarity and consistency must prevail over conplex relational analyses. See also Pittsburgh Terminal Corp. v. Baltinore \& O.R.R., 680 F.2d 933, 942 (3d Cir.) (Rule 10b-5 violation renders reference to other sources of duty to bondholders unnecessary), cert denied, 459 U.S. 1056 (1982); Gardner \& Forence, 589 F. Supp. at 673 ("Fiduciary duties ... do not exist in the abstract, but are derived froin the Indenture itself."); Kessler v. General Cable Corp., 92 Cal. App. 3d 531, 539-40, $155 \mathrm{Cal}$. Rptr. 94, 99-100 (1979) (delisting of stock and debentures because of issuing corporation's acquisition not breach of duty to convertible debenture holders); Levine v. Chesapeake \& O.R.R., 60 A.D.2d 246, 249, 400 N.Y.S.2d 76, 78 (1977) (elimination of public narket for shares was attributable to national economic factors and not actionably unfair to bondholders).

Broad and opinions following it tend to restrict analysis to the four comers of a debt instrument. Even good faith becomes a limited notion, a product of the "parties' intent" rather than a fairness norm imposed from outside. See, eg., Gardner \& Florence, 589 F. Supp. at 673 (implied covenant of good faith derives substance directly from Indenture's language and cannot give debenture lolders any rights inconsistent with those set out in the Indentures); Katz v. Oak Indus., 508 A.2d 873, 897 n.7 (Del. Ch. 1986) (corporation's duty of good faith to bondholders differs from its duty to stockholders).

124. See Bratton, Convertible Bonds, supra note 10, at $695-96$ (neoclassical interpretive mode could lead to bondholder protection); Bratton, Interpretation, supra note 10, at 389-92, 396-97 (same). The courts do not liew to the classical approach so closely that they deny themselves a look at the broader context of transactions and the relative values exchanged and risks assumed. Commonly, they turn to classical principles even as their scrutiny of interactions leads them to conclude that no cognizably unfair action has occurred. The choice of operative conception appears to determine the doctrinal treatment. The Broad opinion, in which the court followed its interpretive ruling with a defense of the faimess of the issuer's action, provides a good example of this approach. See 642 F.2d at 956-57 ("Insofar as the debt feature of the Debentures is concerned, [the holders] benefitted by the merger in that the Debentures are now backed by a financially more secure corporation."); see also Levine, 60 A.D.2d at 248, 400 N.Y.S.2d at 78-79 (affirming dismissal of complaint because "there was no actionable unfaimess to the plaintiffs in these transactions"). 
the drafting burden. ${ }^{125}$ To meet the burden, issuers must show contract language that clearly permits the result they seek. In addition, issuers' duties of good faith prevent actions harmful to bondholders. ${ }^{126}$

The caselaw's normative duality reflects the coexistence of the traditional and investment conceptions. Neither conception holds a monopoly, and the caselaw reflects this fact. Yet, the traditional conception dominates. Intervention to restrain debtors' opportunistic behavior remains occasional and tentative-a supplemental strain. ${ }^{127}$ Moreover, even courts influenced by the investment conception contimue to respect traditional structures; they tend to intervene under contract rubrics and avoid the fiduciary alternative. Contract seems inore traditional and thus lends legitimacy to creditor-protective intervention. Contract lets the court intervene and at the same time uphold the traditional assumption that contract parties are the primary lawgivers. Fiduciary law, in contrast, holds out the possibility that judicially articulated norms of conduct may inhere in a relationship, whether or not the actors would themselves apply them. ${ }^{128}$ Despite the lessons of the investment conception, courts hesitate to make this normative assertion. ${ }^{129}$

125. The investment conception provides necessary support for this approach. It rebuts the claim that open-ended contract interpretation creates costly uncertainty. See Bratton, Interpretation, supre note 10, at 402-03; see also Sharon Steel Corp. v. Chase Manhattan Bank, 691 F.2d 1039, 1053 (2d Cir. 1982) ("We believe it undermines the plain purpose of the redemption provisions to allow a liquidating debtor to avoid their terms simply by failing to take the steps necessary to redeem the debentures, thereby creating a default. We hold, therefore, that the redemption premium must be paid."), cert. denied, 490 U.S. 1012 (1983).

126. See Van Gemert v. Boeing Co., 520 F.2d 1373, 1383-84 (2d Cir.), cert. denied, 423 U.S. 947 (1975) (duty of reasonable notice to protect small investors); Sharon Steel, 691 F.2d at 1053 (bondholders granted redemption premium since debtor liquidated voluntarily, and therefore could have avoided default).

The good faith norm can apply against creditors as well as debtors. See K.M.C. Co. v. Irving Trust Co., 757 F.2d 752, 761-63 (6th Cir. 1985) (lender liable for refusing to disburse funds from discretionary line of credit); Sahadi v. Continental II. Nat'1 Bank \& Trust Co., 706 F.2d 193, 198-99 (7th Cir. 1983) (lender who called loan after minor default could be liable for borrower's losses); State Nat'l Bank v. Farah Mfg. Co., 678 S.W.2d 661, 681-82 (Tex. Civ. App. 1984) (lender liable for misrepresenting intention to call loan); see also Rosenberg, An Overview of Workouts from the Perspective of the Institutional Lender, 16 LoY. U. CHI. L.J. 1, 13 (1984) (borrower can sometimes assert lender's lack of "good faith" as defense to lender's actions upon borrower's default); Note, The Growth of Lender Liability: An Economic Perspective, 21 GA. L. REv. 723 (1987) (examining Irving Trust, Sahadi, and Farah).

127. See Bratton, Interpretation, supre note 10, at 372, 407 (advocating movement away from traditional norms of interpretation when oportunistic debtor behavior goes unsanctioned).

128. See DeMott, Bejond Metaphor: An Analysis of Fiduciary Obligation, 1988 DuxE L.J. 879, 887.

129. The inability of the investment conception to break this pattern of response can be analogized, albeit roughly, to the antimanagerialist model's contemporaneous failure to dominate over the business judgment tradition. See Bratton, Historical Perspectives, supra note 29. In both cases, older managerialist notions and apparent market acquiescence in them dominate the ethic of investor protection. 


\section{E. The Agency Conception: Corporate Debt as a Traded Security}

Financial economics is a relatively new, but influential, field. ${ }^{130}$ Its assumptions and findings have becone ubiquitous in academic writing on corporate law, though its influence on caselaw has been limited. ${ }^{131}$ Writers in the field have articulated a third, "agency," conception of corporate debt-equity relationships.

The financial economists who articulate the agency conception draw on the method and techniques of neoclassical microeconomics to inodel low varions financial instruments and policies affect firm value. ${ }^{132}$ Their 1nodels depict rational, wealtl1-maximizing economic actors operating in a smiple, equilibrated world. Corporate investors becoine atomized price takers competing in perfect capital markets. ${ }^{133}$ Corporate investınent becomes corporate securityliolding.

Transposed to legal theory and applied to debt-equity relationships, financial economics counters both the traditional and investment conceptions. Although many norms common to the traditional conception inform financial economic models, the models lave a radically different foundation. The transactions of rational economic actors bear no resemblance to the einotionally charged engagennents of traditional holistically nodeled borrowers and lenders. Financial economics instead builds on the idea of debt as investinent in manageinent corporations. In so doing, however, it discards the dependent, long-term investors who populate the

130. Financial economics emerged between the mid-1950s and mid-1970s. Its proponents claim to be providing a "scientific" basis for the study of financial behavior. M. JENSEN \& C. SMTTH, THE MODERN THEORY OF CORPORATE FINANCE 2-3 (1984). The field has a cohesive analytical core; basic criticism of its operative paradigm is not entertained. And, despite the abstract and esoteric nature of much work in financial economics, the financial markets have shown a strong demand for those trained in the field. Whitley, The Transformation of Business Finance into Financial Economics: The Roles of Academic Expansion and Changes in U.S. Capital Markets, 11 ACCT. ORGs. \& Soc. 171, 174, 172 (1986).

131. In the courts, financial economics has served as a back-up source of authority. In a number of recent cases involving conflicts of interest between stockholders and bondholders, courts have found themseives in need of outside norms. Microeconomics can have influence at this margin. The courts, accordingly, invoked the "needs" of the market in addition to the expectations of the parties. For example, the court in Broad v. Rockwell Int'1 Corp., 642 F.2d 929, 943 (5th Cir.) (en banc), cert. denied, 454 U.S. 965 (1981), bolstered its narrow reading of a trust indenture with the assertion that "[a] large degree of uniformity in the language of debenture indentures is essential to the effective functioning of the financial markets." A Second Circuit panel in Sharon Steel Corp. v. Chase Manhattan Bank, 691 F.2d 1039, 1048 (2d Cir. 1982), cert. denied, 460 U.S. 1012 (1983), also took this approach. The court worried that "enduring uncertainties as to the ineaning of boilerplate provisions would decrease the value of all debenture issues and greatly impair the efficient working of capital markets."

132. M. JENSEN \& C. SMITH, supra note 130 , at 2-3.

133. Whitley, supra note 130 , at 175 . 
investment conception, replacing them with investors who protect theinselves by holding and trading debt securities in a marketplace.

The agency conception appeared in the 1970 s, prompted by postwar economic changes. The capital markets, aided by Depression-era legal reforms, had reached maturity. By offering a reliable place for trading, ${ }^{134}$ the markets gave practical encouragement to the "securitization" that hes at the center of the agency concept. The inflation and interestrate volatility of the 1970 s accelerated the securitization of debt. Rate volatility undercut the institutional practice of holding debt to maturity and caused stepped-up trading. ${ }^{135}$ The rise of vigorously competitive financial intermediaries also encouraged securitization. ${ }^{136}$ These institutions, with their well-diversified portfolios, practiced the economists' selfprotective theories ${ }^{137}$ and made this practice available to small investors. ${ }^{138}$

1. The Tenets of Financial Economics. Five theories underlie financial economics. Thrce of these, the irrelevance lypothesis, the efficient-market hypothesis, and the capital asset pricing model, lave tremendous import for finance practice but bear only incidentally on the structure of corporate law. The other two theories, the option pricing model and agency theory, define a inodel of corporate financial relationships that bears immediately and fundamentally on corporate legal theory.

134. See A. Kaufman \& L. Zacharias, The Problem of the Corporation and the Problem of Social Values 1 (1987) (unpublished manuscript; copy on file in offices of the Duke Law Journal) (The market is "premised on the individual's equal treatment, broad participation, and reasonable expectation of "just," or even 'fair,' rewards.").

135. For example, secondary trading in treasury bonds increased tenfold between 1978 and 1985. During the $1980 \mathrm{~s}$, the junk bond market arose, responding to the demand for tradable debt securities. This market joined institutional investors and smaller issuers who were formerly tied to the old-form private placement; it made high-coupon corporate debt immediately available. See McDaniel, Bondholders I, supra note 10, at 414-16; Taggart, The Growth of the "Junk" Bond Market and its Role in Financing Takeovers, in MERGERs AND ACQuismons 5, 6-11 (A. Auerbach 4th ed. 1988).

136. See Taggart, supra note 135, at 7. Bank trust departments, insurance companies, investment companies, pension funds, and large corporate treasurers' offices all compete. See Whitley, supra note 130 , at 181 .

137. Today, the pensiou funds alone hold one-third of the equity securities of publicly traded companies, and half of the equity securities of the largest public companies. See Lipton, Corporate Governance in the Age of Finance Corporatism, 136 U. PA. L. REV. 1, 7 (1987).

138. In contrast, during the first decades of this century, when commentators first focused on the unprotected small investor, a handful of investment bankers dominated the capital markets and individuals did not tend to lold investments through intermediaries. Whitley, supra note 130, at 181. 
a. The irrelevance hypothesis, the efficient-market hypothesis, and the capital asset pricing model According to the irrelevance hypothesis, if a firm's investment policy is a given (ignoring tax and transaction costs), the firm's financing decisions have no effect on its current value. This "irrelevance" obtains because investors can coinpete with the firm in the financial markets. Investors can borrow and lend among themselves, adjusting their financial strategies to offset any disequilibria caused by firms' financing activity. ${ }^{139}$ The theory implies that financing devices, including debt instruments, do not imcrease firm value.

Although a revolutionary financial proposition, the irrelevance hypothesis lias little bearing on corporate law, because it involves heroic assumptions and lacks imstitutional context. ${ }^{140}$ Irrelevance obtains only in perfect markets in which all securityholders share the same inforination and make the same value-maximizing decisions. Under these conditions, investors will be immune to injury from opportunistic behavior by management or other securitylolders-they will have completely hedged their portfolios against this risk at zero marginal cost. ${ }^{141}$ Irrelevance, then, operates in a world of markets so perfect that firms play no role. Conficts of interest, the bread and butter of corporate law, do not exist.

The efficient-market lypothesis and the capital asset pricing model, in contrast, have well-known substantive implications for corporate law. In efficient markets, securities' prices always reflect all publicly available

139. This is the famous Modigliani-Miller theorem. See Modigliani \& Miller, The Cost of Capital, Corporation Finance and the Theory of Investment, AM. ECON. REV., June 1958, at 261; Horrigan, The Ethics of the New Finarice, 6 J. Bus. ETHICs 97, $97-98$ (1987); see also A. BARNEA, R. Haugen \& L. Senbet, Agency Problems and Financial Contracting 7-12 (1985) (summ8rizing the Modigliani-Miller arbitrage theorem).

140. See Carney, The Theory of the Firm: Investor Coordination Costs, Cantrol Premiums and Capital Structure, 65 WASH. U.L.Q. 1, 11 (1987) (even assuming that irrelevance hypothesis is substantially correct, contractual solutions to co-investor conflict still lead to elaborate capital structures). Oddly, the irrelevance hypothesis has had a stranglehold on commercial-law theory. See, e.g., Buckley, The Bankruptcy Priority Puzzle, 72 VA. L. REv. 1393, 1469 (1986); Schwartz, The Continuing Puzzle of Secured Debt, 37 VAND. L. REV. 1051, 1068 (1984); Schwartz, Security Interests and Bankruptcy Priorities: A Review of Current Theories, 10 J. LEGAL STUd. 1, 7.9 (1981); White, Efficiency Justifications for Personal Property Security, 37 VAND. L. REV. 473, 508 (1984). The hold, however, is broken in Shupack, Soiving the Puzzle of Secured Transactions, 41 RuTGERS L. REV. - (forthcoming, 1989) (arguing that reliance on economic theory alone is not adequate to guide policy concerning secured transactions, because it does not reflect common experience that loans will not be collateralized).

141. ReCEnt Advances in Corporate Finance 87-88 (E. Altman \& M. Subrahmanyam eds. 1985) (editors' introduction to Part IN); Litzenberger, Some Observations on Capital Siructure and the Impact of Recent Recapitalizations on Share Prices, 21 J. FIN. \& QUANT. ANAL. 59, 60 (1986). Furthermore, in a world of irrelevance, managers need not ponder financing decisions, since the choice does not affect their firm's total value. Horrigan, supra note 139, at 99-100. 
information ${ }^{142}$ and absorb newly released information quickly. The capital asset pricing model asserts that risk caused by events unique to a firm has no effect on the firm's value because investors can easily eliminate that risk by diversifying their portfolios. The only risk that matters is the volatility of the firm as a part of the market as a whole. ${ }^{143}$ These theories make many of the injuries and valuation problems addressed by corporate and securities law disappear. Even when the theory does not vitiate a given problem, the possibility that investors will protect themselves by diversifying makes the problem seem less acute. ${ }^{144}$

Yet, these theories, like the irrelevance lypothesis, lack an institutional component. They address only markets; ${ }^{145}$ they do not explain firms. The capital asset pricing model, carried to its logical conclusion, even negates the firm's traditional entrepreneurial function: since only market risk carries rewards, managers shonld not bother to take unique business risks. ${ }^{146}$ In these theories' world of coinplete self-protection, many of the law's procedural and ethical concerns become inexplicable. The theories, thus restricted, provide no basis for direct evaluation of the structural assumptions and propositions of corporate law.

\section{b. Agency theory and the option pricing model Agency theory} brings financial economics to the firm and the basic structures of corporate law. It models the firm as a "nexus of contracts" among factors of production. The theory focuses almost exclusive attention on bilateral contracting, ${ }^{147}$ deconstructing the managerialist firm envisioned by Berle

142. Some commentators suggest that prices only partially reflect such information. See Gilson \& Kraakman, The Mechanisms of Market Efficiency, 70 VA. L. REv. 549, 642 (1984) (analyzing information flow as a market in itself, whose forces interact with those of capital markets to explain efficiency of securities prices); Wang, Some Arguments That the Stock Market Is Not Efficient, 19 U.C. DAvIS L. REV. 341, 401 (1986) (even if stock market is efficient in "information-arbitrage" sense that it quickly reflects all available information, it might not be efficient in the "fundamentalvaluation" sense of reflecting discounted present value of rational expectations of future dividends).

143. Horrigan, supra note 139 , at 102.

144. Proponents of these theories tend to claim that the theories have well-established empirical backing. See, eg. M. JENSEN \& C. SMTrH, supra note 130, at 4. For a persuasive argument to the contrary, see Whitley, supra note 130, at 175-76 (efficient-markets hypothesis is unfalsifiable because it does not state what relevant information reflected in prices is, how it is identified, or how investors use it; the capital asset pricing model's numerous tests are inconclusive).

145. A. Kaufman \& L. Zacharias, supra note 134, at $2 \mathrm{n.3}$ ("Throughout the course of the modem corporation's development, economists have-sought to develop a scientific basis for comparing the corporation's efficiency, as a means of organizing the allocation of resources ..., with the efficiency of the market.").

146. See Horrigan, supra note 139, at 102.

147. See Bratton, Nexus of Contracts Appraisal, supra note 12 (Under the nexus-of-contracts approsch, "[ $t$ the firm's separate characteristics are found to be insignificant, and determinant significance is attached to relationship's aggregate parts. This approach distills a contractual essence from the corporation."). 
and Means. Agency theory also overcomes the irrelevance model's limitmg assumptions, making possible the theoretical reconstruction of corporate institutions withim the framework of neoclassical microeconomics.

The theory describes financial relationships in terms of agencies. Supphers of capital hire managers as their agents. Rational agents, who retain some freedom to pursue their own ends, tend to shirk on the job and behave in other opportunistic ways with respect to the capital invested. The theory, breaking with the irrelevance hypothesis, relaxes the assumption of perfect information; information asymmetries prevent market self-protection from curing all conflicts of interest. These failures of self-protection give rise to "agency costs." Contracting can reduce these costs and imcrease a firm's value. ${ }^{148}$ Indeed, the contractual devices that make up complex capital structures exist to control agency costs. ${ }^{149}$ Their asserted positive effect on firm value rebuts the irrelevance hypothesis.

Agency theory does not, however, deny the efficacy of self-protection by market trading and other simple purchase-and-sale arrangements. ${ }^{150}$ The theory recognizes two market solutions in particular: portfoho diversification ${ }^{151}$ and unification-ownership of a fraction of each of the outstanding ownership imterests in a firm corresponding to that interest's fraction of the whole. ${ }^{152}$ But agency theory asserts that these devices cannot completely solve conflict-of-interest problems. ${ }^{153}$ Complex financial contracting results. But cost-reductive capital structures turn out to create their own conflict-of-interest problems among

148. See Jensen \& Meckling, Theory of the Firm: Managerial Behavior, Agency Costs and Ownership Structure, 3 J. Fin. Econ. 305, 333 (1976). This analysis rebuts the assertion of irrelevance theory that tax and bankruptcy considerations provide a complete explanation for the connection between capital structure and firm value. E.g., Lehn, Blackwell \& Marr, The Economics of Leveraged Takeoves, 65 WASH. U.L.Q. 163, 177-78 (1987) (variation in optimal debt-equity ratios presumably arises from differing tax advantages and expected bankruptcy costs). The upshot of this agency costs analysis is that different industry groups may have different optimal capital structures. Jensen and Meckling suggest that higher debt-equity ratios will appear where management has only minimal freedom to manipulate a firm's asset base, as with utilities. Jensen \& Meckling, supra, at 355.

149. See A. Barnea, R. Haugen \& L. Sendet, supra note 139, at 2 (process of resolving agency problems gives rise to complex financial instruments); Camey, supra note 140, at 4-5.

150. See, e.g., A. BARNEA, R. HAUGEN \& L. SENBET, supra note 139, at 63, 65-66 (describing "informal reorganization," a capital structure adjustment recommended for firms in trouble).

151. See Carney, supra note 140, at 61-62.

152. A. Barnea, R. Haugen \& L. Senbet, supra note 139, at 63-64.

153. Id. at 104. Carney details the real-world limitations. Diversification creates its own agency costs and involves transaction costs. Unification underestimates the diverse risk preferences of investors and involves contimuing costs of adjustment to the fractional portfolio. See Camey, supra note 140 , at 11-19. 
securityholders. ${ }^{154}$ These problems, in turn, encourage further diversification, unification, and coinplex contracting.

Agency theory asserts that three distinct costs determine the structure of debt-equity relationships: asset substitution, underinvestment, and bankruptcy. ${ }^{155}$ "Asset substitution" follows froin the Black-Scholes option pricing model, a fifth tenet of financial economics. ${ }^{156}$ That model reintcrprets equities as combinations of options to buy and sell a firm's assets. Stockholders, in effeet, hold an option to buy back the firm from bondholders. The value of stock, viewed as an option, increases with the volatility of the firm's earnings. ${ }^{157}$ Thus, given borrowing, stockholders want the firm to invest in high-variance projects, even projects less valuable to the firm as a whole than substitute projeets with lower variance. "Underinvestment" costs arise when the firm's ability to repay its debt depends on the returns from future investinents. If underinvestment obtains, stockholders confronted with an investinent decision want the firm to invest only in projects with a value that exceeds the cost of the project plus the face value of the debt. Otherwise, the firm exerts itself solely for its creditors' benefit. Given limited liability, stockholders might as well walk away in that event, even when the foregone investment is "profitable."158 "Bankruptcy costs" include the out-of-pocket and other costs of corporate reorganization. Agency theory views bankruptcy proceedings as a result of contract failure. Perfect financial contracts, if anyone could draft thein, would establish reorganization bargains in advance. ${ }^{159}$ Agency theorists assert that bankruptcy costs are not as high as popularly assumed. ${ }^{160}$

154. These include the entire range of disputes that arise among securityholders of a given firm-conflicts between stockholders and bondholders, between preferred and common stockholders, between senior and junior creditors, and so forth.

155. These costs are in addition to ancillary costs of monitoring and bonding. See Jensen \& Meckling, supra note 148, at 337-38. If monitoring were costless, firms could nuore effectively control the three central agency costs. Malitz, On Financial Contracting: The Determinants of Bond Covenants, Fin. MGMr., Summer 1986, at 18, 20.

156. See Black \& Scholes, The Pricing of Options and Corporate Liabilities, 81 J. Pol. Econ. 637 (1973).

157. A. BARNEA, B. HAUGen \& L. SENBET, supra note 139, at 33-34; see Horrigan, supra note 139 , at 98.

158. See A. Barnea, R. HAugen \& L. SenBet, supre note 139, at 35-37 (given debt outstanding, stockholders maximize their wealth by accepting an investment only if its nuarket value exceeds the debt obligation); Myers, Determinants of Corporate Borrowing, 5 J. FIN. EcoN. 147, 164-65 (1977); see also Lehn, Blackwell \& Marr, supra note 148, at 177 (stockholders might forgo profitable projects when cash flows from sucli projects are insufficient to retire maturing debt).

159. A. Barnea, R. HAugen \& L. Senbet, supra note 139, at 35.

160. The universal citation is Warner, Bankruptcy Costs: Some Evidence, 32 J. FIN. 337 (1977), a study of 11 railroad bankruptcies betwcen 1930 and 1955. Warner concluded that a bankruptcy costs an average of $2.5 \%$ of firm value during the three years preceding the bankruptcy. Id. at 343 . 
Asset substitution, underinvestment, and bankruptcy become more problematic, and generate larger and larger agency costs, as a firm's leverage mcreases. ${ }^{161}$ Similarly, risks of these costs under an individual loan loom larger as the loan's term becomes longer. ${ }^{162}$ The agency costs of debt, then, are the costs of financial distress. ${ }^{163}$

161. See Jensen \& Meckling, supra note 148, at 342 (agency costs of debt include opportunity wealth loss caused by effect of debt on investment decisions and bankruptcy costs). Compare Gavish \& Kalay, On the Asset Substitution Problem, 18 J. Fin. \& QUANr. ANAL. 21 (1983) (increases in stockholder wealth do not depend monotonically on leverage ratio) with Green \& Talmor, Asset Substitution and the Agency Costs of Debt Financing, $10 \mathrm{~J}$. BANKING \& Fiv. 391 (1980) (presenting model in support of notion that increased debt heightens stockholders' incentives to take risk). For discussions of asset substitution in the legal literature, Barkey, The Financial Articulation of a Fiduciany Duty to Bondholders with Fiduciary Duties to Stockholders of the Corporation, 20 CRE1GH. TON L. Rev. 47, $51-52$ (1986) (discussing the Black-Scholes model); Levmore, Monitors and Freeriders in Commercial and Corporate Settings, 92 YALE L.J. 49, 66-68 (1982) (discussing the JensenMeckling model).

162. Carney, supra note 140, at 63; Klein, supra note 32, at 1561.

163. Malitz, supra note 155 , at 20. Scholarship under the agency paradigm conibines analysis of incentives and the bargaining dynamic to explain the provisions, devices, and patterns of debt contracting. Inquiry focuses on the debt contract most problematic fron the agency-cost perspective, the long term unsecured loan. Private placements, that is, long-term debt contracts that closely constrain debtors' conduct, are made by riskier borrowers. These borrowers generate higher agency costs and have more of an incentive to reduce these costs by contract. In contrast, public debt offerings by better creditors reflect few such constraints. Id. ; see also Smith \& Warner, On Financial Contracting: An Analysis of Bond Covenants, 7 J. FiN. EcoN. 117, 150 (1979) (private placements generally contain more restrictions than do public issues).

Commentators have explained each of the standard business covenants in agency-cost terms. For example, prohibitions on excess investment in marketable securities deter asset substitution, and limitations of dividends to amounts earned or raised through issues of new equity inhibit underinvestment by forcing firms to maintain the asset base. Id. at 125-26, 131-35; Malitz, supra note 155, at 19; see also Handjinicolaou \& Kalay, Wealth Redistributions or Changes in Firm Value: An Analysis of Returns to Bondholders and Stockholders Around Dividend Announcements, 13 J. Fin. ECON. 35, 57, 59 (1984) (announcements of dividend reductions signal unexpected reductions of future cash flows, and cause losses to bondholders, who will share decreases in firm value with stockholders).

Easterbrook's work in agency theory puts this debtor-creditor picture in the larger context of management-stockholder relations. Malagement's undiversifiable investment in human capital causes risk aversion regarding debt burdens; this risk aversion causes conflict with stockholders' interests. Wealth transfers froin stockholders to bondholders are hypothesized: the bondholders buy bonds with the understanding that management will act in the stockholders' interest, but management instead pursues its own niterest, causing the agency cost of the debt to be less than the bondholders anticipated. Following this reasoning, Easterbrook explains steady dividends to the stockholders as devices that force management to eschew conservative retained earnings financing and to keep the debt-equity ratio higher than management's self-imterest would dictate. The outflows of cash also force management to go to the capital niarkets for financing, which results in momitoring that benefits the stockholders. Easterbrook, Two Agency-Cost Explanations of Dividends, 74 AM. ECON. Rev. 650, $653-54$ (1984). Easterbrook's nodel, however, is flawed. Market experience in the 1970s made bondholders unlikely to price issues on the assumption that managenuent would naximize the value of the firm to the stockholders. On the contrary, bondholders bought issues from the better credits on the assumption that self-interested nuanagement behavior would obviate the need for business covenants. See infra text accompanying notes 213-14. 
Thus, the agency conception of debtor-creditor relationships focuses on the same scenarios as do the traditional and investment conceptionsdistress situations. But agency theory describes a different pattern of distress. On the one hand, it depicts debt and equity interests in sharper conflict than previously supposed. This intensified conflict stems from the option pricing inodel's switeh of the source of equity value from expected return to volatility. ${ }^{164}$ On the other hand, agency theory breaks new ground in minimizing the practical import of such conflicts of interest. The agency model's rational economic actors forecast agency problems and form unbiased expectations regarding their impact. ${ }^{165}$ Creditors anticipate debtors' self-interested behavior and adjnst loan charges accordingly. As a result, debtors bear the agency costs and have an incentive to offer contract provisions to eliminate this pricing effect. ${ }^{166}$

2. Rebuttals of Received Legal Theory. The agency theorists' view of the corporation deconstructs and rebuts both traditional and investment-based legal theory.

a. Rebuttal of the traditional conception. In the "nexus-ofcontracts" firm, all factors of production come to the firm on an eqnal footing. Contracting settles details of the various interestholders' participations in the firm. Equity loses its property-based identity with the firm; ${ }^{167}$ its participation is restated in contractual terms. Furthermore, agency theory extends the investment conception's association of debt and equity to a point of conceptual identity. ${ }^{168}$ Creditors' and stockholders' "contractual" participations differ in details, but not in essence. 169

164. Agency theory thus partly rebuts the managerialist assertion that stockholders and bondholders have common interests. See, eg., Jensen, Agency Costs of Free Cash Flow, Corporate Finance, and Takeoper, 76 AM. ECON. REv. 323, 323-24 (1986).

165. A. BARneA, B. Haugen \& L. SenBet, supra note 139, at 25-26.

166. Jensen \& Meckling, supra note 148, at 345. This point is disputed. Compare Barnea, Haugen \& Senbet, An Equilibrium Analysis of Debt Financing Under Costly Tax Arbitrage and Agency Problems 36 J. Fn. 569, 579 (1981) (bondholders bear costs) with Roberts \& Viscione, Note on Who Pays the Agency Casts of Debt, 19 Fnv. REV. 232 (1984) (lenders and borrowers share costs; both groups benefit from cost reduction).

167. See supra notes $29-32$ and accompanying text.

168. See supra notes $82-83$ and accompanying text.

169. Different commentators describe this conflation of equity and debt variously. One author joins equity and debt as different forms of "ownership," see Carney, supra note 140, at 60-61, another as different forms of "loans," see Lehn, Blackwell \& Marr, supra note 148, at 172-73. See also Anthony, supra note 36, at 246 (arguing that financial economic conception of firm should be assimilated into accounting -an approach that would displace historic proprietary theory and result in accounting for equity as a cost); Easterbrook \& Fischel, Close Corporations and Agency Costs, 38 STAN. L. REV. 271, $274 \mathrm{n.8}$ (1986) (no fundamental difference between equity and debt from an economic perspective). However, one of the new works in the field, Grossman \& Hart, The Cost and Benefits of Ownership: A Theory of Vertical and Lateral Integration, 94 J. PoL. EcoN. 691 (1986), at 
The agency model deconstructs the management corporation by focusing all attention on individual actors and their bilateral contracts. It breaks the managerialist reification of the corporate debt-equity relationship, ${ }^{170}$ returning us to a world of individual debtors and creditors. But it does not thereby revive the contracting dynamic of the traditional conception. The rational economic actors who populate agency theory are crcatures of academic models rather than holistically modeled actors drawn from history. Their relentless rational behavior precludes the fear and moralism traditionally attached to financial distress. High debtequity ratios are not the product of questionable, risk-prone behavior. And bankruptcy no longer appears as the product of failure, with moral implications. ${ }^{171}$

b. Rebuttal of the investment conception. Agency theory also rebuts the imvestinent conception, by "securitizing" debt investinents. Debtholders treat the same bonds, debentures, and notes differently under agency theory. They do not expect to hold this debt for twenty years; they consider exit by market sale a constant possibility.

The investment conception does not deny that investors trade, of course. But its debt-equity picture does not highlight trading; instead, it centers on the managerialist corporate entity. Under managerialism, individuals tend not to matter except as members of groups; only groups enjoy cognizable power and interests. Bondholders thus are depicted as a group, instead of as individuals trading in a marketplace. The bondholder group's capital is sunk in the corporate debtor, rather than retrievable through the sale of a security. Moreover, management exercises power over the capital imvested. In the agency conception, in contrast, management does not exercise power over investors by virtue of its special position in the production process; it is just another contracting party in the nexus. ${ }^{172}$

3. The Normative Implications of Agency Theory.

a. The contractual hierarchy. Financial economists bring individualist values to their models. They prefer people to be free-standing and independent. For this reason, they consider the best contracts to be

least holds out the prospect of a return to an association of equity and ownership. Grossman and Hart identify ownership of an asset with possession of residual rights of control over the asset and suggest that in a world of complete contracts, there is an optimal allocation of residual rights of control. Id. at 692 .

170. See supra text accompanying note 19.

171. See Lehn, Blackwell \& Marr, supro note 148, at 174-75. (conceiving bankruptcy as a contractual problem caused by a shortfall of cash).

172. See Bratton, Nexus of Contracts Appraisal, supra note 12. 
discrete contracts, that is, impersonal arm's-length exchanges that objectify all aspects of a relationship into concrete terms, particularly the price. These economists consider relational contracts-exchanges that do not objectify all matters ex ante and entail future contact between the parties, along with their subjective interaction-appropriate only as costavoiding backstops. ${ }^{173}$

These values have positive and normative ramifications. The positive assertion is that rational actors resort to discrete contracts first, turning to coinplex, relational contracts only when discrete inarket solutions generate unnecessary costs. The normative assertion is that parties should not expose themselves to agency costs avoidable by contract and should explore discrete solutions first. These two assertions imply a preference hierarchy among the contracting devices that shape corporate relationships. Diversification and unification constitute the most discrete devices, since investors can unilaterally use them in the marketplace. Financial ecomomic inodels therefore predict that those devices will predominate; the inodels fault parties who pass up self-protective opportunities.

As applied to debt contracts, these inodels predict that coinplex contracts will appear only when the last-ditch discrete device, the price, leaves a party bearing minecessary agency costs. ${ }^{174}$ This point occurs when a loan's long term makes financial distress an unavoidable contracting contingency. A normative result, readily transferable to legal doctrine, parallels this prediction. The norm is a presumption against the existence of legally cognizable noncontractual injuries between corporate debtors and creditors.

b. Financial economics at various points in the hierarchy-neoclassical and institutional models and their respective implications for legal theory. Although economists tend to subscribe to the values just discussed, they differ in their applications of thein, modeling corporate relationships at different places in the contractual hierarchy. Some assume that discrete contracting solves all problems. Others argue that fidelity to real world conditions requires abandonment of this assumption; these economists' models occupy lower rungs. Generally, as a model admits more contract failure and moves down the ladder, (a) the parties' con-

173. See supra notes $139-41,150-54$, and accompanying text; infra notes $175-77$ and accompanying text.

174. Significantly, the irrelevance school of financial economics does not attempt to introduce complex contracts or agency costs into its inodel. With assumptions of perfect markets and full information, it inodels debt and equity in a completely discrete world. See supra notes $139-41$ and accompanying text. 
tracts become more relational, (b) corporate structures become more complex, (c) possibilities for legally cognizable injury intensify, (d) the model becomes less neoclassical and inore institutional, and (e) the model inore closely resembles the received legal model.

i. Neoclassical models. Economists who make neoclassical assumptions analyze corporate structure largely in terms of discrete contracts. They account for the differences in the legal imcidents of debt and equity by associating equity control with residual risk. Although debt and equity start as common factors of production, equity, as the residual risk-bearer, has greater incentives to momitor and reduce production costs. This approach reaffirms the status quo: the traditional legal structure, which accords stockholders the vote and inakes debt "contractual," turns out to be efficient. 175

Cruder neoclassical models go a step further and emphasize stockholders' opportunities for self-protection through discrete contracting. These models challenge the legal status quo for overstating corporate fiduciary duties: inarket actors do not want all the legal protection they currently get; they prefer discrete devices like diversification and market exit. 176 The law also overstates duties responding to the moral hazard of risky investinents by highly distressed, leveraged firms: since creditors can easily protect themselves and often do, they can incur no legally cognizable injury. ${ }^{177}$

ii. Institutional models. Economists writing in the opposing, institutional tradition abandon the focus on the discrete contract, instead modeling corporations as ongoing relationships. ${ }^{178}$ In their view, market self-protection never works perfectly, opening up possibilities for one individual's or group's appropriation of capital from another. Various firm participants face various risks of expropriation. Equityholders bear the greatest risk because they hold the residual claim. Even as equityholders

175. Fama \& Jensen, Separation of Ownership and Control, 26 J.L. \& ECoN. 301, 303 (1983); see Easterbrook \& Fischel, Voting in Corporate Law, 26 J.L. \& EcoN. 395, $401-402$ (1983) (corporate structure facilitates benefits of division of labor); Fama \& Jensen, Agency Problems and Residual Claims, 26 J.L. \& ECON. 327, 328 (1983) (residual risk borne by those who contract for rights to net cash flows).

176. The most famous work in this genre is Easterbrook \& Fischel, Corporate Control Transactions, 91 Y ALE L.J. 698 (1982).

177. See Easterbrook \& Fischel, Limited Liability and the Corporation, 52 U. CH1. L. REv. 89, $104-06$ (1986).

178. See generally $O$. Williamson, The Economic Institutions of Capitalism: Firms, MARKETS, RELATIONAL CoNTRACting (1985) (adopting economic perspective based on institutional models); Williamson, The Modern Corporation: Origins, Evolution, Attributes, $19 \mathrm{~J}$. EcoN. Lrr. 1537 (1981) (analyzing modern corporate form as series of organizational innovations). 
respond by diversifying, the law enhances their position by providing for voting control and imposing fiduciary duties on managers. ${ }^{179}$

This analysis of equity can extend to long-term unsecured debt. With high debt-equity ratios, even well-protected debt becomes vulnerable to expropriation. The institutionalists acknowledge this point, but step back from the implication that debtholders should receive voting power and fiduciary protection, citing the availability of protective contracting. ${ }^{180}$ But this step back does not eliminate the extension, which opens the possibility of legal protection. If contract failure can be demonstrated, the institutional analysis provides a theoretical justification for legal protection of creditors. ${ }^{181}$

iii. Connections with the traditional and investment conceptions. Norms that shape the neoclassical version of the agency conception tend to resemble those that shape the traditional conception. Enmity and selfprotection dominate both. Injuries need not result in intervention under either. And, prior to insolvency, with its well-defined legal implications, neither leaves much of a role for the law, other than to make contracts enforceable.

The institutional rendering of the agency conception contradicts this simple picture. By abandoning fidehty to the discrete contract, and stressing the dangers attending long-term investments, it opens the possibility of legally cognizable injury. But even as the institutionalists reconstruct aspects of the imvestment conception, they do not deny the relevance of self-protection by inarket ineans. Nor do they make a normative commitment to recognize injury to debtholders in every case of issuer opportunism. In effect, then, they revisit the juxtaposition of the traditional and investment conceptions in postwar legal theory, combining their ambivalent elements under the aegis of one theory.

179. See Carney, supra note 140, at 64 (investors reserve decisionmaking rights); Williamson, Corporate Governance, 93 YALE L.J. 1197, 1204-12 (1984) (analyzing net gains to corporate constituencies from representation by board of directors).

180. Carney, supra note 140, at 66-67; see Williamson, supra note 179 , at 1211-12 (lenders deserve board representation in atypical circumstances). The approach of Oliver Williamson, the leading institutionalist, exemplifies the extension and the step back. Extending, he notes the vulnerability caused by high debt-equity ratios. Stepping back, he notes that, in practice, debtholders begin to intervene at this stage through management consultation. Id.; see also Klem, supre note 32, at 1562 (as investment's duration lengthens, number of contingencies increases and capacity to deal with them diminishes; solution is to distribute power among all long-term investors); Levmore, supre note 161 , at $80-82$ (exploring implications of economic similarity of debt and equity interests in context of creditor derivative suits).

181. See McDaniel, Bondholders $I I$, supra note 10, at 245-51. 


\section{F. Summary}

The traditional, investment, and agency conceptions offer different and limiting models of the bondholder. Each model actor has a distinctive behavior pattern, and each behavior pattern has normative implications. Selecting a model actor charts a particular direction for normative responses to debtor-creditor conflicts.

But none of the models suffices for all purposes, because in practice, there is no quintessential bondholder. Real bondholders act in ways materially more complex than those depicted in any of the three models. Today, a variety of investors hold corporate bonds. Soine are large entities and individuals occupying positions of power with respect to their debtors; others are large institutions with diversified portfolios; still others are largely uninfluential and undefended individuals. The same variety of actors hold corporate equities; many hold portfohios of equity and debt. As inflation and other economic forces shift, these actors weight and reweight their debt-equity portfohos. ${ }^{182}$ Some liolders treat their debt and equity holdings as discrete contracts; indeed, given securitization, this lias become common practice. Even so, some holders stay more involved with their investınents. Relationally conceived and structured corporate debt remains a practical possibility.

Because there is no single bondholder, and because corporate law tends to be sensitive to the contingencies that result, no one model of the bondholder has taken an exclusive hold on legal doctrine. The three debt-equity conceptions coexist in the law. ${ }^{183}$

By accepting the conceptions' coexistence, we sanction contradiction in the law. But we do not thereby accept incoherence or introduce additional indeterminacy. There is no single bondloolder, but there are bond contracts. Contract texts give the debt-equity relationship an objective center of gravity and formal integrity. They allow us to defer the selection of an imperfect inodel actor to the secondary plane of textual interpretation. At that level, the conceptions compete to shape the imterpretation of the texts. ${ }^{184}$ Significantly, the texts are sufficiently comprehensive to limit the permitted range of normative interpolation. Thus, in

182. McDaniel, Bondholders I, supra note 10 , at 417.

183. The agency conception has particular relevance to the determination of contemporary legal issues. It has close ties to the forces that have changed the markets during recent years. Therefore, it joins the still-ascendant traditional conception as a determining influence in the law. The two coexist with little friction, complementing and reinforcing one another in most situations. At the same time, the investment conception has lost force. The practical developments that make agency ideas influential undercut the investınent conception's assumptions. Today's self-protected investors are less dependent on manageinent discretion and probity.

184. See generally Bratton, Interpretation, supra note 10 
practice, the law's imperfect model bondholders play interstitial roles. They play leading roles only in theory.

This distinction between the function of texts and the function of models explains the present state of corporate debtor-creditor doctrine. In particular, it explains the traditional conception's persistence: that conception protects the texts of debt instruments and the associated contract-based interpretive model from the more personalized and tortoriented legal model used for other corporate relationships. So long as this protective instinct dominates lawmaking, neither the investment conception nor the agency conception can come to dominate the law. ${ }^{185}$ At the same time, these conceptions function as supplements, ensuring that the law recognizes relational elements omitted in the traditional conception.

\section{Conceptions of Corporate DeBt, Bondholder Wealth Transfers, aND High DEBT-EQuity Ratios}

Restructurings disrupt the postwar pattern of relations among management, equity, and long-term debt interests. They realign power, causing management and debt to suffer while equity gains.

Recapitalizations are the means to the end of restructuring. They come in several transactional modes: friendly mergers, hostile tender offers followed by mergers, leveraged buyouts, and defensive recapitalizations. Whatever the mode, recapitalizations entail the payment of a bonus to equityholders, financed by substantial borrowing. ${ }^{186}$ The new borrowing injures existing bondholders: in effect, it transfers value froin their securities to the equity's premium. Beginning in 1985, when large corporations began to undergo restructurings, these wealth transfers made bondholder protection a prominent legal policy question for the first time simce the Depression era. Another aspect of the restructuring movement, the incidence of higher corporate debt-equity ratios, also has prompted new policy discussions. This part of the Article considers re-

185. The traditional approach gives the text primacy over the managerialist assertion of investor dependence. This view resonates with the broader relationship between managers and debtholders: the text gives the debt investor a reservoir of power for times of financial distress. Since the traditional approach is constitutive and text-based, it stands apart from the contractualism of the agency approach, which is behavioral, instrumental, and based on economic theory. Just as the continuing presence of contract texts has prevented debt-equity relations from collapsing into the managerialist model of the corporation, there to be manipulated for the policy objectives of one or another group, so texts prevent a collapse into the agency model.

186. Corporations also finance such a bonus by selling their assets. This tends to occur in connection with, but subsequent to, borrowing: a corporation borrows capital to finance the bonus to the equity and pays down the loan by subsequent asset sales. 
structuring-related wealth transfers, the new debt-equity ratios, and the legal responses to them.

\section{A. Bondholder Wealth Transfers}

The three conceptions of debt-equity relationships discussed in part I suggest normative responses to the restructuring-related wealth transfers. Each response shapes events to fit the informing conception. Each therefore has a plausible empirical basis even though it fails to reflect the entire picture of events. Nothing inherent in wealth transfers dictates that any one of the three conceptions be apphed to the exclusion of the other two. Thus, none of the responses achieves indisputable theoretical validity.

The legal result, however, is not in doubt. The traditional conception holds. It approves wealth transfers and encourages restructurimg transactions, but ouly up to the insolvency threshold. Near the insolvency line, it constrains restructurings that involve unacceptably high leverage.

The first subsection that follows describes the wealth transfers and the contracting practices that permit them. The second subsection evaluates the legal responses. The third subsection takes up a special set of legal responses-applications of fraudulent conveyance law to leveraged buyouts that skirt insolvency. The fourth and last subsection describes inarket responses.

\section{Restructuring and Bondholder Wealth Transfers.}

a. Incidence and magnitude. Restructurings began when players in the capital markets lost their tolerance for corporate investment policies keyed to management's preferences. ${ }^{187}$ Restructuring transactions undo the effects of suboptimal investment practices, returning suboptimally invested capital to equityliolders. ${ }^{188}$

High debt-equity ratios serve the restructuring objective in several ways. New borrowing finances the imitial return of capital to the equity. Given an antecedent capital structure shaped by risk-averse inanagers,

187. Restructurings dissolve the implicit agreement between management and the capital markets concerning corporate investment power. The investment community used to accept management's pursuit of corporate "growth" passively. Managers were left alone because they had special expertise in investment policy. This idea held despite the fact that managers' personal needs for institutional security often led to investments at risk levels lower than stockholders' interests would dictate. Even if a corporation's management made manifestly suboptimal investments, the costeffective stockholder response was to sell, rather than to attempt to challenge management directly in order to force changed policies.

188. See Bratton, Historical Perspectives, supra note 29. 
new borrowing also raises the debt-equity ratio and lowers the corporation's overall cost of capital because of savings from the tax deductibility of interest payments. ${ }^{189}$ The higher debt-equity ratio encourages management discipline in the future, because interest payments on debt are mandatory, while dividends on stock are discretionary. The heavy debt load forces management periodically to return substantial capital to the investment community. No extra capital is left for suboptimal investment. 190

The "wealth transfers," therefore, are incident to a wider shift in corporate debt-equity relations. The transfers occur prior to or at the start of a restructuring. They victimize the holders of the restructured corporation's long-term, unsecured debt securities. To use agency language, leverage imcident to restructuring increases these debtholders' agency costs. To use plainer language, the preexisting debt becomes riskier and falls in price as the issuer's debt-equity ratio rises.

Restructuring first jeopardized the bonds of large corporations in 1985. It brought sudden price drops and concomitant downgradings of formerly high grade bonds. The Unocal and Phillips Petroleum transactions were the most notorious. In each case, the restructured company's bond rating fell froin AA to BBB. ${ }^{191}$ In another famous case, an issuer's announcement of a one time special dividend as a defensive move caused its bonds to drop $\$ 200$ in value. ${ }^{192}$ Even rumors of a tender offer can

189. See I.R.C. § 163(a) (West 1988).

190. Jensen, supra note 164, at 323-24. In Jensen's parlance, the substitution of interest payments for dividends "bonds" the promise to pay out future cash flows. Of course, the higher debtequity ratio results in higher agency costs for debt. See supra note 161 and accompanying text.

Ironically, heavy indebtedness might make management less risk-averse. Managers anxious to lessen risk by paying down debt may be enticed by the big pay off held out by a risky investinent. Coffce, Stockholders Versus Managers: The Strain in the Corporate Web, 85 MrCH. L. REv. 1, 62, 65-66 (1986) Thereinafter Coffee, Corporate Web]. In Coffee's parlance, a higher debt-equity ratio pushes up managers' "aspiration level." Id. at 65.

The "management-disciplinary" explanation of the restructuring movement is a reduction. It suffices for present purposes, subject to the caveat that the real world is more complex. See Coffee, The Uncertain Case for Takeover Reform: An Essay on Stockholdens. Stakeholders and Bust-Ups, 1988 WIS. L. REv. 435, 441-43 [hereinafter Coffee, Takeover Reform].

191. Farrell, Takeovers and Buyouts Clobber Blue-Chip Bondholders. Bus. WK., Nov. 11, 1985, at 113.

192. McDaniel, Bondholders II, supra note 10, at 209 (Colt Industries). The wealth transfer effect occurs as an incident of each of the major modes of restructuring: leveraged buyouts (Macy's announcement of a leveraged buyout caused its stock to go up $\$ 16$ and its notes to drop 3 points), hostile tender offers followed by inergers (Unocal's and Phillips Petroleum's bond ratings fell from $A A$ to BBB after firms took on debt to deter corporate raiders), defensive restructurings (CBS's AArated bonds dropped 4 poimts upon the announcement of an exchange of new debt for old equity in reponse to Ted Turner's tender offer), friendly mergers (the merger of $A B C$ and Capital Cities caused the credit ratings of both to drop; $11.75 \%$ debentures of Capital Cities traded at 85 basis points above Treasury bills prior to the inerger and traded at 125 basis points above Treasury bills 
cause bonds to fall. ${ }^{193}$ The phenomenon continues unabated, as the food company restructurings of fall 1988 demonstrate. ${ }^{194}$

Since 1985, downgradings because of the risk of restructuringcalled "event risk" by the bond-rating agencies-have become commonplace. Bond analysis no longer considers only corporate fundamentals and the business cycle. ${ }^{195}$ In 1986, downgrades at Standard \& Poor's exceeded upgrades by a two-to-one ratio; one-third of these downgrades related to restructurings. ${ }^{196}$ In the same year the record number of industrial bond downgrades exceeded upgrades by 4.2 to 1.197 By mid1987 , the median grade for an industrial bond was a speculative $B B$; in 1982 the median grade had been A. ${ }^{198}$

Different observers make different assessments of the wealth transfers' magnitude. If one focuses only on the bonds affected and their prices before and after the events in question, the amounts transferred seem impressive. Bond analysts point out that a one-grade drop from AA to A causes a $5 \%$ to $6 \%$ drop in market value; a drop from $\mathrm{A}$ to $\mathrm{B}$ causes a $15 \%$ to $20 \%$ drop in market value. ${ }^{199}$ The Unocal bondholders alone lost the substantial sum of $\$ 170$ million. If one shifts perspective to look at each restructuring transaction as a whole, however, the quantum of bondholder imjury seems less impressive. The face value of two issues of Unocal bonds declined only $4.2 \%$ and $3 \%$ respectively. ${ }^{200}$ At the same time, the Unocal stockholders received \$2.8 billion. ${ }^{201}$ Economic studies generalize on this lesson. They recognize significant bondholder

after the merger). See Farrell, supra note 191, at 113; Prokesch, Merger Wave: How Stock and Bonds Fare, N.Y. Times, Jan. 7, 1986, at A1, col. 1. For a discussion of the particular effects of restructuring transactions on the value of convertible bonds' conversion privilege, see Boland, When Bonds Lose their Convertibility, N.Y. Times, Jan. 31, 1988, § 3, at 10, col. 2.

193. McDaniel, Bondholders II, supra note 10, at 209.

194. Wallace, supra note 3, at D1, col. 3 (discussing RJR Nabisco buyout and its effect on bondholders).

195. See McDaniel, Bondholders II, supra note 10, at 208 (Standard \& Poor's Corp. lowered bond ratings in response to corporate leveraging); Farrell, supra note 191, at 113 (rating agencies are lowering rates on takeover targets' securities).

196. Robertson, Debenture Holders and the Indenture Trustee: Controlling Managerial Discretion in the Solvent Enterprise, 11 HARv. J.L. \& PUB. POL'Y 461, 471-72 (1988).

197. McDaniel, Bondholders II, supra note 10, at 208; see also Prokesch, supra note 192, at D4, col. 2. Twenty-seven percent of these downgrades resulted from restructurings. Farrell, supra note 191, at 113. All this-more downgrades than in the recession year of 1982-took place during a bull bond market.

198. McDaniel, Bondholders II, supra note 10, at 208.

199. Prokesch, supre note 192, at D4, col. 2.

200. Lehn, Blackwell \& Marr, supra note 148, at 186-87.

201. Litzenberger has analyzed the Phillips and Unocal data in order to calculate the value transferred from the bondholders to the stockholders. He found that the Phillips bondholders' loss anrounted to a gain of \$0.25/share to Phillips stockholders; the Unocal stockholders gained \$0.042/ share from their bondholders. Litzenberger, supra note 141, at 67,69 . 
losses in individual cases, 202 but stress that the losses are on average so small that stockholder gains outstrip them. ${ }^{203}$ The studies conclude that the wealth transfer effect, while a real benefit to equityholders in restructurings, is not enough of a boon to drive the wider restructuring movement. 204

b. The facilitating conditions: the disappearance of business covenants and the limited force of reputation. Bondholders would not have suffered wealth transfers if the contracts governing their bonds had contained restrictions against additional debt. With covenants prohibiting the transactions, those in control would have had to "take out" the bondholders by prepaying the old debt in order to take on new debt. ${ }^{205} \mathrm{Un}$ fortunately for bondholders, by 1985 trust indentures governing the longterm unsecured debt of large corporations usually did not contain these restrictions.

This practice reflected a change from earhier contracting patterns, a change unnoticed in legal and economic commentary on debt contracts

202. Eg. Taggart, supra note 135, at 19.

203. Lehn and Poulsen's study of leveraged buyouts finds an aggregate loss of $1.4 \%$ to nonconvertible bondholders and $2.5 \%$ to convertible bondholders. The study covers only 37 issues of bonds, however. Lehn \& Poulsen, Leveraged Buyouts: Wealth Created or Wealth Redistributed?, in Public Policy Toward Corporate Takeovers 46, 57-58 (M. Weidenbaum \& X. Chilton eds. 1988). For criticism of this study, see McDaniel, Bondholders II, supra note 10, at 211-12 (bondholders might have experienced significant losses before announcement of the LBOs at issue).

204. See Lehn \& Poulsen, supre note 203, at 46-61; cf. Masulis, The Impact of Capital Structure Change on Firm Value: Some Estimates, 38 J. Fin. 107, 116-18 (1983) (study of recapitalizations involving increased leverage, 1963-1978, confirming wealth transfer effect). But cf. Marais, Schipper \& Smith, Wealth Effects of Going Private for Senior Securities, 23 J. Fin. EcoN. - (forthcoming, 1989) (study of going-private buyout proposals made from 1974 to 1985 finds insignificant negative returns to nonconvertible debt securities).

The financial economics literature includes a large number of studies on the wealth effects of nergers and tender offers. So far as bondholder-to-stockholder wealth transfers are concerned, these studies test two opposing models. One is the agency-costs model. Under this model, the stockholders of an acquiring firm have an incentive to increase the variability of their own firm's cash flow in ways that injure its bondholders. See supra text accompanying notes 156-57. The opposing model, the "coinsurance" theory, holds that the merger of two firms could create a portfolio effect that would reduce the variability of the firms' combined cash flows, transferring wealth to the bondholders. See Dennis \& McConnell, Corporate Mergers and Security Retums, 16 J. Fin. Econ. 143, 179 (1986). The studies show that stockholders of both acquired and acquiring corporations tend to gain in mergers, but that bondholders of both types of corporations tend neither to gain nor to lose. See, eg., id at 184-85 (study showing that preferred stockholders of acquiring companies and preferred stockholders and senior securityholders of acquired companies benefit, with minimal effect on other equity interests). Because these studies cover merger activity ouly through 1980 , they should not be read to contradict the conclusions of empirical studies of the restructuring movement that began in 1985, discussed supra notes 191-204 and accompanying text.

205. When the debt of restructuring companies contains a debt covenant, the bondholders are taken out. Robertson, supra note 196, at 482 . 
until the wealth transfers highlighted it.206 For most of this century, contracts governing long-term debt restricted subsequent substantial indebtedness, along with subsequent dividends and liens.207 Until recently, investors considered these provisions central to the bargain. They served as a substitute for security, protecting debtholders' interest in issuer earning streams from issuer misbehavior. ${ }^{208}$ In financial economic terms, the provisions insulated holders from agency costs. The degree of constraint depended on each issuer's credit standing. Better credits with access to public bond markets faced fewer restraints than smaller issuers making private placements. The best credits issued debt with no restraints other than a debt covenant. ${ }^{209}$

This pattern continued until the mid-1970s. ${ }^{210}$ Since then, new pubhic, unsecured debt of large imdustrials has tended to contain only a "negative pledge" against additional secured debt and a covenant prohibiting the sale and leaseback of issuer assets. Debt and dividend covenants have disappeared, surviving to restrain only smaller issuers.211

When large restructurings commenced, the affected bondholders lacked defenses, but did not seem to know their exposure. Apparently everyone, except for the handful of lawyers and underwriters directly involved and perhaps a few traders and portfoho managers, thought that debt contracts still took the traditional form, or at least supplied some

206. Morey McDaniel has pointed out this change in Bondholders $I$, supra note 10, at 424-26.

207. See, eg., ABF COMMENTARIES, supra note 33, at 369-71, $402-04$ (debt contracts nearly always contain debt and dividend covenants); B. MANNING, supre note 38, at 96-106 (debt contracts always contain debt covenants, dividend covenants, and covenants against competing and senior claims); cf. A. Berle \& G. Means, The Modern Corporation and Private Property 122-23 (rev. ed. 1968) (discussing dividend covenants).

208. Garrett, supra note 55, at $680-81$.

209. Simpson, The Drafting of Loan Agreements: A Borrower's Viewpoint, 28 Bus. LAw. 1161, 1161-62 (1973). Smith and Wamer's study of 87 public issues registered between January 1974 and December 1975 shows that $90.8 \%$ had some prohibition on the issuance of additional debt. Interestingly, only $23 \%$ of the issues contained dividend restrictions. Smith \& Warner, supra note 163, at 122-23. Evidently, the standard picture liad already begun to change in 1974-1975.

210. See Prokescl, supra note 192, at D4, col. 2.

211. McDaniel surveyed the debt contracts of Fortune's 100 largest industrials in 1984. He found that negative pledge and sale-leaseback covenants were ubiquitous. Of the 92 companies reported as having one or more senior issues, one or more subordinated issues, or both, only $28 \%$ of the issues contined debt covenants. Of the newer issues, only $16 \%$ contained a debt covenant. Dividend restrictions appeared in $35 \%$ of the issues, but in only $20 \%$ of the newer issues. McDaniel, Bondholders I, supra note 10, at $425-26$.

Malitz surveyed all long-term senior nonconvertible debentures issued between 1960 and 1980 and described in Moody's Bond Survey or Moody's Industrial Manual. Of these, 49\% contained no debt covenant. Malitz found a negative correlation between the presence of debt covenants and the size of the issuer. Malitz, supra note 155, at 21-24. 
minimal protection. ${ }^{212}$

The covenants had disappeared because they seemed unnecessary. Before 1985 , economic prosperity combined with management's dominant governance position to make large corporations look reliable as unsecured borrowers. ${ }^{213}$ Whatever the turns of the business cycle, management seemed unlikely to seek to benefit stockholders by abusing bondholders. Management wanted growth and security-goals best realized with conservative leverage and retained-earnings financing. Moreover, managers had passed up opportunities to imjure bondholders even when debt contracts posed no obstacle. According to the conventional wisdom, such opportumistic conduct would lead creditors im future financings to impose unfavorable terms, the costs of which would outweigh the benefits of present wealth transfers. ${ }^{214}$

The assumption that management held an unassailable position ${ }^{215}$ ultimately led to questions about the need for covenants. Covenants became a subject of bargaining. ${ }^{216}$ Management characterized covenants as

212. Legal and economic commentators certainly assumed that debt contracts were exhaustively drafted. See, eg., B. Manning, supra note 38, at 96-97; Bratton, Interpretation, supra note 10, at 384; Easterbrook, supra note 163, at 655-56; see also M. JENSEN \& C. SMrrH, supra note 130, at 111 (covenants reduce agency costs and owners benefit in the form of a higher bond price); Asquith \& Kim, The Impact of Merger Bids on Participating Firms' Security Holders, 37 J. Fin. 1209, 1226 (1982) (bondholders on average enjoy protection from potential wealth transfer through mergers; they neither gain nor lose); Handjinicolaou \& Kalay, supra note 163, at 59 (arguing that bondholders pricing bonds will assume that allowable dividends will be paid; any lower dividend rate will transfer wealth from stockholders to bondholders).

In the teeth of the last four years' experience, financial economists still assume that debt contracts contain elaborate and effective protections of bondholders' interests. See, e.g., Carney, supra note 140, at 61-63; Lehn, Blackwell \& Marr, supra note 148, at 175.

213. Between the Depression and the late 1970 s, very little law relating to bonds was made, presumably because bond contracting patterns, investors' expectations, and institutional practices interrelated harmoriously. Reported cases tended to concem the conversion privilege, and even these cases did not arise often until the inerger movement heated up in the late 1970s and early 1980s. See generally Bratton, Convertible Bonds, supra note 10, at 671, 693-98. The other factor that led to friction - and gave management incentives for opportunism-was the rise in interest rates after 1978. See, eg., Morgan Stanley \& Co. v. Archer Daniels Midland Co., 570 F. Supp. 1529 (S.D.N.Y. 1983) (dispute stemming from redemption of high coupon debt); $c f$. Sharon Steel Corp. v. Chase Manhattan Bank, N.A., 691 F.2d 1039 (2d Cir. 1982), cert denied, 460 U.S. 1012 (1983) (low coupon rate explains management disincentive to redeem plaintiff' bonds).

214. Taggart, supra note 135 , at 19. John and Nachman have inodeled reputation as a force that curtails agency costs. Under this model, management reduces underinvestunent without needing the constraint of an explicit covenant; the authors call reputation an "iniplied contract." John \& Nacirman, Risky Debt, Investment Incentives, and Reputation in a Sequential Equilibrium, 40 J. FIN. 863, $870.76(1985)$.

215. Coffee associates the disappearance of restrictive covenants with reliance on management's position. Coffee, Corporate Web, supra note 190, at 68-69.

216. Tight, close-to-perfect sets of covenants, while easy enough to draft (private placement and term loan forns contain them) never appeared in public debt contracts. The rigor of such covenants inight easily cause management to forgo a value-increasing transaction, while conferring no material 
an unnecessary and costly backstop for the bondholders' position. ${ }^{217}$ Since the costs were real and the bondholders confident, management won the point.

The restructuring inovement has shattered the managerialist assumptions behind the covenantless debt contract. The financial markets have proved that the manager-emperors had no clothes. Power over imvestment and financing has shifted to the capital markets. Corporate reputation - the unprotected bondholders' backstop-has proved ineffective. Managers' and stockholders' mcentives to maintain good reputations in the capital narkets do not have the staying power of contract promises; they shift along with power and inoney. Exiting stockholders and managers care nothing about a corporate entity's future financing costs. ${ }^{218}$ Managers battling to stay on might indeed care, but have more immediate problems. As Jensen and Meckling noted in 1976, and bondholders discovered in 1985, sainthood does not have infinite benefits, and agency costs do not reduce to zero. 219

benefit on the bondholders. And, given a dispersed body of bondholders, managers and bondholders would find it hard to loosen tight covenants by contract amendment. Furthermore, the difficulty of executing a binding amendment has created a holdout problem in times of financial stress. See Roe, supra note 103, at 232, 236-39; see also McDaniel, Bondholders I, supra note 10, at 427-28 (discussing problems caused in Chrysler restructuring by negative pledge clause).

217. McDaniel accounts in part for the disappearance of covenants by noting that their value has become dubious - a decline attributable to the reality that loopholes exploitable by good lawyers or creative managers are inevitable. See McDaniel, Bondholders II, supra note 10, at 236-38; see also Coffee, Corporate Web, supra note 190, at 69 (theorizing that use of covenants has declined because no covenant could cover all of the ways that management can increase bondholders' risk). But this contracting problem, often obscured in the discussion, is not inpossible to address effectively, even though contract perfection is unattainable. Any junior associate can draft a set of showstopping covenants. The basic elements of restructuring - borrowing, security, dividends and other payments to stockholders, and inergers and sales of assets-are the bread and butter of traditional business covenants. The problem stems from drafters' inability to foresee the future. If drafters could overcome this problem, they could impede precise injurious potential transactions without constraining management in other legitimate activity. Since the drafters cannot foresee the future, effective protections are necessarily overimclusive. This overinclusiveness has costs.

Today, given several years of experience with restructuring-related wealth transfers, one could casily draft a covenant that would permit a restructuring to go forward and would not injure bondholders. Such a covenant would tie a change in the interest rate to stated increases in the issuer's debtequity ratio. See Wallace, supra note 3, at DS, col. 3 (bondholders seeking to protect investments by using covenants that increase interest rates on buyout or restructuring).

218. Oesterle, The Negotiation Model of Tender Offer Defenses and the Delaware Supreme Court, 72 CORNELL L. REV. 117, 139-40 (1986) ("'TT]endering stockholders may seek to maximize their exit payout at the expense of these other constituencies. Stockholders will leap at a premium price and transfer control to a bidder even if they realize that the new owner will default on corporatc obligations to nonstockholders."); see Lebron, Games Corporations Play: A Theory of Tender Offers, 61 N.Y.U. L. REv. 153, 203 n.169 (1986) (usual reputational constraint against exploitation of bondholders does not apply in tender offer context).

219. Jensen \& Meckling, supra note 148, at 351. 
2. Legal Responses. The three conceptions of corporate debt shape law and commentary ${ }^{220}$ on restructuring-related wealth transfers, as the following discussion shows.

a. The traditional conception. As we have seen, the traditional model remits a creditor seeking recourse against a solvent debtor to contract. 221 Under this conception, wealth transfers incident to restructurings that do not bring the debtor near insolvency create no right of action absent a covenant. At or near the insolvency line, however, payments to stockholders and new creditors can amount to fraudulent conveyances.

Corporate law reinforces this result by giving inanagement substantial discretion over bondholder relations. ${ }^{222}$ The discretion works both ways: within broad limits, management may either benefit or injure bondholders. As long as it can show some rational connection to corporate profit and stockholder gam, ${ }^{223}$ inanagement may not only effect wealth transfers, but may forgo them.224 It also has discretion to maintain debt-equity ratios and other aspects of financial structure that benefit itself and its bondholders but are suboptimal froin the stockholders' point of view.225 And it may accept business covenants, including covenants that deter hostile tender offers. 226

The Delaware courts consistently apply these principles. In a rccent case, the Chancery Court noted bondholders' restructuring-related injuries, but applied the traditional conception: no right absent an indenture

220. No imjured bondholder's lawsuit challenging a wealth transfer has yet prompted an appellate opinion, nor have bondholder wealth transfers figured into congressional policy discussions regarding corporate indebtedness in connection with restructurings. However, various legislative proposals would discourage the issuance and holding of junk bonds. See CONGRESSIONAL RESEARCH SERV., Library OF CONGRESS, U.S. CONGRESS, CoRPORATE MERGERS ANd High Yield [JuNK] BONDS: RECENT MARKeT TRENDS AND Regulatory Developments 3 (1986) [hereinafter CRS, RECENT TRENDS].

221. See supra text accompanying note 33 .

222. This response is a combination of the corporate-law principle that management has a primary duty to stockholders, see, eg., Oesterle, supra note 218, at 138-40 (analyzing management representation of stockholder and nonstockholder interests in context of wealth transfers), and the business judgment rule which curtails judicial review of management decisionmaking.

223. RESTATEMENT OF CORPORATIONS, supra note $34, \S 2.01$ (objective and conduct of the corporation).

224. In the latter case it would presumably justify its action by asserting that the corporation's market reputation would benefit.

225. See generally G. Donaldson, Managing Corporate Wealth: The Operation of a Comprehensive FinANCIAL GOALS SYSTEM 42-57 (1984) (discussing corporate finance from inanagement perspective).

226. Cf. Fox v. MGM Grand Hotels, Inc., 137 Cal. App. 3d 524, 187 Cal. Rptr. 141 (1982) (sustaining spin-off of $50 \%$ of debtor corporation; courts will not take cognizance of bondholders' interest in market value of their investments). 
provision or legislative intervention. In the landmark Revlon case, ${ }^{227}$ the Delaware Supreine Court constrained management's discretion to take defensive action benefiting bondholders in the context of a tender offer defense that involved the breakup of the target. Presumably, the business judgment rule still applies to other bondholder-beneficial manageinent actions.

b. The agency conception Agency theory also sanctions the wealth transfers. Commentators articulate three variations of the theory-strong, intermediate, and weak. The strong mode sanctions the wealth transfers by applying a positive model of the place of debt in corporate structures. The intermediate mode lacks this positive certitude. Instead, it sanctions the wealth transfers on a normative level, drawing on agency theory's individualistic rules of investor self-protection. The weak mode falls outside the standard law and economics pattern; it declines to accord agency theory primary positive or normative force. Even so, the weak inode uses eleinents of financial economics, sometimes giving them determinative weight.

In its strong mode, agency theory combines a strong version of the efficient-market hypothesis with Jensen and Meckling's origimal agency model. A clear, positive picture results-wealth transfers do not raise a legal issue becanse the bondholders suffer no injury in the first place. When rational economic actors price bonds, they discount for the risk of expropriation. The inarket price mipounds this expropriation discount. The bondholders in effect have been paid to bear the risk. ${ }^{228}$

The intermediate mode nakes two modifications. First, it abandons the assumption that bondloolders price debt based on the risk of wealth transfers. Bond prices thus lose determinative force. This modification carries us back to the pre- 1985 world, in which no one had conceived of corporate restructurings. Of course, even before 1985, the rational cconomic actor of the neoclassical models still would have discounted for the theoretieal risk of expropriation. In the intermediate mode, however, the institutional economists' actor, with his bounded rationality, holds the stage. ${ }^{229}$ More closely resembling a real-world bondholder, this investor does not discount the bonds for unheard of future risk. The inter-

227. Revlon, Inc. v. MacAndrews \& Forbes Holdings, 506 A.2d 173, 182 (Del. 1986); see supra note 113 .

228. See Easterbrook \& Fischel, supra note 62, at 105; Lehn, Blackwell \& Marr, supra note 148, at 185; Oesterle, supra note 218, at 140; see also McDaniel, Bondholders II, supra note 10, at 238-45 (in the aggregate, bond prices reflect expropriation risk, since market model assumes diversified bond portfolio).

229. See supre notes $\mathbf{1 7 8 - 8 1}$ and accompanying text. 
mediate mode also uses a weaker version of the efficient-market hypothesis. ${ }^{230}$ In this version the most sophisticated traders are completely rational and take account of all risks, but the market.price only partially reflects these traders' information level. ${ }^{231}$ Together these assumptions mean that bondholders have not been paid to bear the risk of restructuring injury. This conclusion returns us to the starting point. Bondholders have sustained an injury; the question is whether the injury is tortious.

Commentators in the intermediate mode make their second modifcation at this point in the analysis. They apply the normative assumptions of financial economics to rebut the implication of a tort. Financial economics calls for self-protection: if you can protect yourself with a contract, then you should do so, unless you can show that positive law protection serves the same function more chcaply. Since, by established practice, bondholders always ean self-protect with a covenant, ${ }^{232}$ they cannot successfully argue for implied-im-law duties. Injuries from bondholders' failure to protect themselves fall among the inevitable dislocatious that occur in free-market economics. ${ }^{233}$ The capital asset pricing model positively and normatively reinforces this result by trivializing bondholders' injuries. Rational bondholders diversify to reduce the risk of expropriation; the law should not compensate irrational bondholders who fail to protect themselves in this way.

Commentators who espouse the weak version of the agency approach reject an absolute norm of self-protection. They draw on corporate legal theory for countervailing norms. Contrary to the strong mode, corporate legal theory does not embrace the pure agency model. More forgiving of error and folly, it continues to mix the idea of the rational economic actor with more realistic and hohistic models. Whole persons sometimes fail to protect themselves. This failure is an integral part of the legally recognized behavior pattern. ${ }^{234}$ For the same reason, the indi-

230. For discussion of the normative implications of applying the various versions of the efficient-market hypothesis to bondholder wealth transfer problems, see Bratton, Convertible Bonds, supra note 10, at 704-08.

231. Grossman \& Stiglitz, On the Impossibility of Informationally Efficient Markets, 70 AM. ECON. REV. 393, 393-95 (1980).

232. See Lehn, Blackwell \& Marr, supra note 148, at 185; Oesterle, supra note 218, at 140. Commentary in this mode always neglects to analyze why fiduciary duties are cost beneficial only as apphed to stockholders. Why would not a new model of the corporation, in which stockholders, too, "get covenants," better manifest the free contracting that underlies the financial economies models? Under the received model, of course, stockholders need not contract for protection. But financial economies does not accept the received legal model as inevitable.

233. Cf. Easterbrook \& Fischel, supra note 62, at 104-06 (voluntary creditors are compensated for the risk they bear when they do not contract for protections).

234. Coffee, Corporate $W e b$, supra note 190, at 50-51. 
vidualist norm applied in the intermediate mode is not an absolute mandate; the law adjusts to excuse failures in some situations. The weak Inode, in effect, takes this approach. It applies the tools of financial economics together with notions of investor protection and relational values such as solidarity. This wide range of norms leaves considerable room for argument over which norm should determine the legal result in a given situation. If investor protective and relational norms are accorded determinative weight, then a case for legal protection is articulated. At soine point, of course, arguments for legal protection become so strong as to dissolve ties to agency literature; such analysis would occupy a gray area between the agency and investment conceptions.

The leading exemplar of commentary in the weak inode, that of Professor Coffee, does not go so far as to dissolve ties to the agency conception, however. Coffee uses the tools of financial economics to sustain the conclusion that restructuring-related wealth transfers are nontortious. This analysis of the wealth transfer issue probably would persuade most observers in the legal profession, whether academics or practitioners. ${ }^{235}$ It therefore inerits close consideration.

Coffee compares bondholders with the other primary victims of wealth transfers, managers. Both groups can contract for protection but often do not. Yet, Coffee implies legal protection only for the managers. To reach this result, he balances various imdeterminate factors, most of which ultimately come from the financial economists' individualist toolbox. For example, in Coffee's view, managers make an expropriable firm-specific investment, but bondholders do not, because bondliolders can diversify. ${ }^{236}$ Moreover, although Coffee's approach does not demand perfect self-protection, he notes that bondholders can adjust for future uncertainties by demanding covenants, by insisting on a direct voice im corporate decisionmaking, or by simply avoiding long-term unsecured debt securities. ${ }^{237}$ Although bondholders dispensed with covenants in rehance on management's apparently durable structural power, that reliance was cnlpable-bondholders took a "frce ride" on management's known aversion to risk. ${ }^{238}$ In any event, Coffee reasons, the law should recognize that stockholders' gains from restructurings outstrip bond-

235. Market practices provide at least some support for this result. Given the securitization of debt investments, investors have substantial opportunities to protect themselves. Although bondbolders have been incurring real losses, self-protective practices might fairly be assumed to have softened these losses. And possibilities for contract modification make the ongoing policy problem of debt and restructuring less than urgent. The next generation of contracts can contain covenants.

236. For an extensive discussion, sec Bratton, Nexus of Contracts Appraisal, supra note 12.

237. Coffee, Corporate Web, supra note 190 , at 50.

238. Id. 
holders' losses. ${ }^{239}$

Coffee's analysis, while powerful, does not preempt the field of debate in this mode. A bondholder-protective critic can work free of it, arguing that Coffee's practical balancing exercise has a weak normative base and makes an incomplete analysis of culpability. Coffee's "freeriding" bondholder is certainly no more, and perhaps less, culpable than other actors in a restructuring. Though the managers whom Coffee favors suffer greater loss and have less of a chance to proteet themselves, their self-interested behavior makes the bondholders' free ride possible and, inore generally, provokes restructurings in the first place. ${ }^{240}$ Nor is it clear that bondholders ride "free." The cost savings achieved by the abandonment of covenants does not necessarily accrue to bondholders. It might benefit borrowers or fall into both pockets.

This normative criticisin of Coffee extends to his differential treatinent of bondholders and managers. His individualist attack on the bondholders coexists uneasily with his relational recognition of inanagers' injury. ${ }^{241}$ To support this treatment, Coffee's inodel renders the manager as a whole person, but the bondholder as a cardboard cutout patterned by financial economics. The observer's subjective understanding of the flesh-and-blood manager counters the impulse to apply an individualistic norm. Yet Coffee's bondholders receive no such charity. This approach does have a basis in fact-in today's securitized world, inanagers seem more like whole people than do investors. But, as we have seen, no single inodel of the bondholder suffices. Real people with real stakes in bonds, whether as investments or eareer vehicles, suffer injury, even though most bonds belong to the faceless inanagers of diversified portfolios. There exists no primciple in private legal theory that lets us compensate one injured person, but not one who belongs to a second, indistinguislable group and sustains an equivalent injury.

This argument against differential treatınent of managers and bondholders can be restated affirmatively to support legal bondholder protection. It can even be stated so as to admit the relevance of the main points

239. Id. at 51 .

240. Management seems to have initiated the omission of covenants. Significantly, the commentator most vigorously promoting a managerialist response to the restructurings, McDaniel, asserts that covenants provide bondholders with inefective protection. See supra note 217; infra notes 249 . 52 and accompanying text.

241. Of course, dislocated managers are real people; for that reason, their imjuries command more attention. Though real people hold bonds, portfolio diversification and other devices protect most of these beneficiaries from injury. This distinction, while real, fails to explain the division of rights in restructurings. The chief beneficiaries of such events, holders of common stock, are no more "real" than the bondholders. 
of agency theory. The contract-law good faith duty ${ }^{242}$ provides a doctrinal framework within which this balance can be struck. The good faith duty permits judicial intervention against one-sided performance of particular contracts. The intervening court restores balance and ethical substance to exchanges that have becoine nonreciprocal in the course of a long performance period. The intervention is ex post in perspective, and the substantive inquiry is ad hoc in scope. In contrast to a corporate fiduciary duty, the intervention imphes no commitment to an extended future of legal protection..$^{243}$

In the context of restructuring-related bondholder injury, a court could base a good faith duty on parties' expectations of secure capital structure as actually apphed in high-grade bond valuation until 1985, when high-grade bond issuers became vulnerable to restructuring. Linniting the duty's apphication to this pre-1985 bond inarket expectation follows from recognition of the concerns of agency theory. But this approach limits the effect of agency theory in turu. The self-protective possibilities it highlights would determine the legal outcome only for bonds issued after 1985, with respect to which self-protection by narket actors could be expected as a practical matter.

This compromise solution would be subject to legitimate attack from both sides. It would not solve the problem of bond contract failure by imposing a clear prospective allocation of restructuring risk. Nor would it fully vindicate the self-protective norm, or incorporate the lessons of agency theory on their own terms. Moreover, good-faith-based judgnients in favor of bondholder plaintiffs would disrupt the legal status quo and thereby result in new rounds of wcalth transfers between issuers and bondholders. The rebuttal to these practical criticisms would emphasize wider normative objectives. To those arguing for full bondholder protection, the response would be that judicial intervention to protect securityholders never amounts to a mandate for perfect contracting. Instead, it causes parties to focus attention on particular problems. More importantly, it makes a supplemental rather than primary outside contribution to the normative patteru of the parties' relationships. This contribution is in part symbolic; the parties can choose to disregard it. But it also has a bondholder-protective practical impact: it puts the burden of specificity on the party who seeks to disrupt settled expectations. To those arguing for full application of agency principles, the response would be that the ad hoc, ex post character of intervention under the

242. See supra notes 122-26 and accompanying text.

243. I articulate a good-faith-based approach along these lines in Bratton, Convertible Bonds, supra note 10, at 714-19. 
good faith rubric always leaves the terms of future transactions open to negotiation. ${ }^{244}$ Issuers seeking to impose restructuring risk on bondholders can do so securely and cheaply by adding a simple sentence to this effect in their bond contracts.

c. The investment conception. Proponents of the investment conception make an unqualified case for bondholder protection. They depict restructuring-related wealth transfers as a contract failure, then pursue one of two lines of argument. Some advocate a fiduciary duty to bondholders. Others advocate legal intervention in the contracting process to make debt contracts more bondholder-protective.

i. Fiduciary duty. Berle suggested reconstructing corporate law to redirect management efforts to serving the balanced interest of all investors. ${ }^{245}$ Advocates of a fiduciary duty to bondholders take a Berlian approach: they reject the "nexus-of-contracts" conception, ${ }^{246}$ modeling the firm as an entity in which various interest groups pursue long-term relationships subject to management's higher power. Then they introduce points basic to the investment conception: stocks and bonds are simply different versions of long-tern investment in firms; therefore, bondholders should not be excluded from participation in firms. From these tenets fiduciary duty advocates suggest a management duty to maximize the value of the firm from stockholders' and bondholders' combined perspectives. ${ }^{247}$

As they must, the fiduciary duty advocates reject the agency analysis of wealth transfers. First, they question the strong agency model's assertion that bond prices reflect risks of restructurings, stressing the unex-

244. Functional considerations do not make a compelling case against bondholder protection. Bondholder protection in law would not necessarily impede value-maximizing transactions. See Lehn, Blackwell \& Marr, supra note 148, at 185-86. If market actors found such protection inappropriate, they could draft it out of future contracts in a sentence or two. Bratton, Convertible Bonds, supra note 10 , at $718-19$.

245. A. BERLE, supra note 28 , at $191-92$.

246. See supra text accompanying note 147 .

247. McDaniel, Bondholders II, supra note 10, at 303-05. McDaniel supports his position with a survey of cases involving stockholder-bondholder disputes. Id. at 274-304. He contends that when a transaction that affects stockholders' and bondholders' wealth is not Pareto-efficient, the courts intervene to award damages to the bondholders, thereby elevating the transaction to Pareto-efficient status. Id. at 304 . Barkey, supra note 161 , at 68 , claims that a "generic managerial fiduciary duty" requires management to utilize assets efficiently for the joint benefit of stockholders and bondholders. Surprisingly, Barkey supports this asserted fiduciary duty with financial economics, particularly the option pricing model. He states that the model's view of the firm as a possession of bondholders, subject to stockholders' option to repurchase, reflects bondholders' "first equitable ownership" of corporate assets. Id. at 69. 
pected nature of many restructurings. 248 Second, they dispute the intermediate mode's assertion that bondholders can readily and cheaply obtain full contractual protection. Covenants, they argue, cannot effectively regulate corporate borrowers' opportunistic conduct. ${ }^{249}$ Moreover, market strategies like diversification and exit provide less than complete protection in the real world. Exit works only with slowly deteriorating issuers; diversification never perfectly eliminates risks. "Bondholders," a diverse group of individuals and institutions, have different cost bases for their investments and different self-protective capabilities. No market strategy will ever eliminate the possibility of injury to such a group. ${ }^{250}$ On a more positive note, the advocates claim that a bondholder fiduciary duty would be efficient. By offering everyone investinent security, the duty wonld reduce agency costs. ${ }^{251}$ Moreover, the expense of judicial enforcement of the duty would not be burdensome..$^{252}$

Three substantial barriers confront the argument for a bondholder fiduciary duty. First, the investinent conception influences corporate law only marginally. Even the few cases that recognize a fiduciary duty do not suggest that it overrides the provisions of bond contracts. Second, the advocates' managerialist conception of the firm no longer fully describes business practice. Nor does it command universal acceptance in the legal community. Finally, the duty derives fronı a broader management duty to pursue optimal returns on invested capital. But the law, while it requires manageinent to pursue profit and gain, ${ }^{253}$ does not measure managenient performance against an optimality standard. The business judginent rule restricts judicial scrutimy of managenient's investnent decisionmaking, and corporate law stops well short of mandating optimal performance even to benefit stockholders.

ii. The contracting process. Sonie advocates of the investnient conception reject fiduciary duties, ${ }^{254}$ turning instead to reform of the contracting process. These commentators also treat wealth transfers as contract failures, but suggest a different remedy. They deem business covenants sufficient, provided that the law can direet market actors to

248. McDaniel, Bondholders II, supra note 10, at 240-45; Barkey, supra note 161, at 69 (bondholder wealth "unanticipatedly expropriated from bondholders").

249. See supra note 217.

250. McDaniel, Bondholders II, supra note 10, at 243-45; McDaniel, Bondholders I, supra note 10 , at 433-36.

251. McDaniel, Bondholders II, supre note 10, at 245-51.

252. Id. at 251-52 (projecting approach to damage calculation in succcessful bondholder aetion).

253. See supra note 34 and accoinpanying text.

254. Robertson, supra note 196, at 483 (Fiduciary duties ignore the "essential difference in the nature of the legal claims asserted by both stockholders and debenture holders."). 
include sufficiently strong ones. Regulation-in the form of a corporate trustee empowered and required to exact contract protections-is the means to this end.25s

This approach provides a useful technical counter to the fiduciary duty arguments. Considered in the abstract as a reform proposition, it makes substantial sense. But it has overwhelming practical problems. Mandatory covenants imposed under the auspices of "supertrustees" would depart from the tradition of free contracting in corporate debtorcreditor relationships, a departure not taken even during the Depression. This contract reform analysis, couched in old-fashioned policy terns, will not attract a substantial constituency today.

No essential "error" mvalidates either argument from the investment conception. They identify real contract failure. Yet, they misjudge its magnitude, at least in light of today's financial community's values. Self-protective practices diminish the urgency of the contract failures, making prescriptions of fiduciary duties and process intervention seem overwrought. These prescriptions become persuasive only in the event that views on the desirability of restructurings take a sharp negative turn.

\section{The Traditional Conception as a Barrier to Deals: The Special} Case of the Leveraged Buyout. The three debt conceptions interact in surprising ways in the commentary on leveraged buyouts (LBOs). The coinmentators want to avoid intervention against highly leveraged restructurings under the traditional insolvency standard. Toward this end, they link the investinent and agency conceptions. The conjunction is unique and noteworthy-in effect, investor-protective concepts come together with aspects of agency theory that facilitate investor injury.

LBOs involve leverage so high that restructured companies sometimes start life at or near insolvency. As is usual with restructuring transactions, acquirers "take out" stockholders with the proceeds of new borrowing. The target does not receive proceeds of this borrowing, even though its assets are pledged to secure the debt. If the transaction skirts insolvency, the target's creditors can make fraudulent conveyance objections to the validity of the security interests in its assets and the payments to its stockholders. ${ }^{256}$ Applying basic fraudulent conveyance law, courts have sustained the objections. ${ }^{257}$

255. In appropriate circumstances, a trustee may waive these protections. Id. at 484-85.

256. Carlson, supra note 23, at 74-75.

257. Courts have invalidated mortgages, security interests, and guaranties granted by target corporations that have becoine insolvent, see United States v. Tabor Court Realty Corp., 803 F.2d 1288, 1298-99 (3d Cir. 1986) (applying fraudulent conveyance law to prevent bad-faith mortgage purchases froun defrauding creditors), cert. denied. 107 S. Ct. 3229 (1987), or have been left with 
This situation, at last, presents a case of judicial intervention to protect creditors injured by restructurings. Significantly, the intervention occurs under the rubric of debtor-creditor, rather than corporate law, validating only traditional norms of creditor protection. Still, some commentators question these interventions. 258

Both Baird and Jackson's ${ }^{259}$ and Carlson's ${ }^{260}$ studies argue for relaxation of fraudulent conveyance law's insolvency standard. Incident to an LBO, insolvency has only technical significance. Indeed, they claim it may even give new managers an incentive to work a corporation out of a tight corner. Thus, the threat of legal intervention posed by the insolvency standard may arbitrarily deter useful transactions. Carlson would modify the rule that challenges transactions in which a lender knows that a debtor is insolvent. He would excuse these loans where the lender reasonably beheves that the target can generate enough surplus cash to cover payments on the debt incurred in cormection with the LBO. ${ }^{261}$ Baird and Jackson also question the application of fraudulent conveyance law in these cases, but do not suggest a new rule.

Both Baird and Jackson's and Carlson's works offer the same justification for snstaining LBOs: even though an LBO injures precxisting debt $\mathrm{m}$ the short run, the new nanagement benefits the firm in the long run. ${ }^{262}$ Unfortunately, this justification ignores the realities of an LBO. It relies on a inanagerialist conception of individnal sacrifice for the general good of the corporation. But the managerialism of sacrifice, with its

unreasonably small capital after leveraged buyouts, see Sharrer v. Sandlas, 103 A.D.2d 873, 873-74, 477 N.Y.S.2d 897, 899 (1984) (applying UFCA \& 5 to leveraged buyout). See also Credit Managers Ass'n v. Federal Co., 629 F. Supp. 175, 183-84 (C.D. Cal. 1985) (applying UFCA § 5, but finding that target was not left with unreasonably small capital).

Counsel have objected strenuously. They have argued that since no one had heard of LBOs when the Uniform Fraudulent Conveyance Act appeared in 1924, courts should not assume that legislatures intended the Act to invalidate such transactions. The Third Circuit made short shrift of this argument in Tabor Court Realty, 803 F.2d at 1296-97. See also In re Ohio Corrugating Co., 70 Bankr. 920, 925-26 (Bankr. N.D. Ohio 1987) (applying fraudulent conveyance laws is appropriate and would not jeopardize all LBOs); In re Anderson Indus., 55 Bankr. 922, 926 (Bankr. W.D. Mich. 1985) (language of fraudulent conveyance act is unconditional and clearly applies to LBOs).

258. Practitioners seeking to simplify the law make time-honored arguments for "safe harbors" in the statutes. Kirby, McGuinness \& Kandel, Fraudulent Conveyance Concerns in Leveraged Buyout Lending 43 Bus. LAw. 27, 36 (1987); Murdoch, Sartin \& Zadek, Leveraged Buyouts and Fraudulent Transfers: Life Afier Gleneagles, 43 Bus. LAw. 1, 2 (1987).

259. Baird \& Jackson, supra note 28 , at 851-52.

260. Carlson, supra note 23 , at 95.

261. Id. at $95-100$.

262. Id. at 95; Baird \& Jackson, supra note 28, at 853. Baird and Jackson add the shopworn excuse that a corporation, once taken private, will save the costs of complying with the federal securities laws. Id. 
cooperative aspirations, implies an investment conception of debt. ${ }^{263}$ Under an investinent conception, the sacrificing investor supposedly gets legal protection in return. But, as we liave seen, ${ }^{264}$ corporate law, consistent with its assimilation of the traditional conception, refuses this protection. Even as it accepts fraudulent conveyance principles as a minimal backstop, it continues to exclude creditors from the benefits of firm participation. To cut back on this minimal protection for the corporate entity's benefit is wrongly one-sided-a "leads I win; tails you lose" exercise.

The lack of reciprocity in this approach stands out even inore starkly against the factual background of the standard LBO. An LBO does not occur because proinoters, managers, and financiers decide to improve a corporation for the good of preexisting investors; it occurs because it offers sure profits for the equity taken out and a chance for extravagant, but high-risk, profits for the proinoters and managers who take control and for the financiers who help them. Preexisting creditors share this risk, but get no compensation in the form of a higher interest rate or an option to exit at face value. These creditors" "upside," if the corporation recovers, is to return to their original position-holding a fixed coupon that bars thein from further "upside" possibilities. Of course, when a corporation is suffering a serious decline, this chance to return to square one inay carry substantial benefits. But a rational creditor imight well prefer to explore soine transactional alternatives first. Reinoving fraudulent conveyance protection deprives this creditor of the power to demand consideration of alternative solutions.

The commentators, then, seek to justify LBOs as beneficial recapitalizations for declining corporations, yet they reverse the usual hierarchy of priorities in recapitalizations and reorganizations. Even outside of bankruptcy, creditors generally surrender rights only if equityholders make even greater sacrifices. In LBOs, no one asks for the creditors' consent, and the equity walks away at a premium! The commentators can justify this bizarre resnlt only by intermixing the three conceptions of debt without regard to their origins, positive implications, or normative content. They also draw a narrow, Panglossian picture of LBOs theinselves. At bottoin, this work aniounts to ad hoc apologetics for a popular, profitable transaction form. The work fails as doctrine, policy, and theory.

Baird and Jackson, inspired by financial economics, advance a second theory that withholds protection froin debtholders harmed by LBOs.

263. See supra notes $92-93$ and accompanying text (describing how investment conception depicts relations among debtholders, equityholders, and management).

264. See supre notes $29-42$ and accompanying text. 
They assert that fraudulent conveyance law is essentially contractual and therefore needs narrow interpretation, lest it call for results that parties would not have reached if left to their own contractual devices. ${ }^{265}$ Building on this assertion, Baird and Jackson adopt the intermediate mode of agency analysis ${ }^{266}$ and contend that if contracting creditors really wanted fraudulent conveyance protection, dividend and other covenants that perform the same function should be ubiquitous, which they are not. If creditors forgo protective covenants, the authors reason, they have themselves to blame for their injuries. Replacing fraudulent conveyance law with optioual covenants would prove a superior, more flexible approach anyway. Parties can adjust contracts, but not the positive law of fraudulent conveyances.

With this argument, Baird and Jackson again confront preexisting creditors with a Cateh-22. Positive-law protection is valid only when it saves preexisting creditors the costs of contracting. ${ }^{267}$ But when creditors try to save costs by relying on positive law, Baird and Jackson turn the tables: such rehance proves that the positive law was unnecessary in the first place. Of course, as Baird and Jackson tell us, parties can waive contracts. But they can waive many positive law rights as well. Moreover, in any event, Baird and Jackson have no business throwing waivers in the face of preexisting creditors. A waiver is an act of consent by a party who willingly gives up a right. By proposing to disregard fraudulent conveyance law, Baird and Jackson seek to eliminate the legal requirement that creditors consent to LBOs, all to facilitate valueinaximizing maneuvers by the forces in power. They envision a world of contract inore Orwellian than Snithian.

Finally, fraudulent conveyance law does not prohibit LBOs; it regulates them by limiting permissible leverage. This regulation might go too far, and the traditional mediation of corporate debtors' and creditors' interests, as it applies to these transactions, might need change. To make this case persuasively, however, one must approach the traditional norm on its own terms, showing why its constituent elements no longer support its application. Until someone makes this case, however, the courts would do well to ignore this commentary on LBOs. ${ }^{268}$

265. Baird \& Jackson, supra note 28, at 834-36 (fraudulent conveyance law should attempt to provide an agreement that the parties would have made).

266. See supra notes $232-33$ and accompanying text.

267. See supra note 28.

268. See, eg., Sherwin, Creditors' Rights Against Participants in a Leveraged Buyout, 72 MinN. L. REV. 449, 490-96, 505-21 (1988) (courts should apply fraudulent conveyance statutes to LBOs to protect creditors against overreaching or undue risk, but courts, in applying fraudulent conveyance remedies, should consider the business setting of the LBO at issue and the risk of discouraging legitimate business acquisitions). Baird himself has articulated a modified position that recognizes 
4. Responses in Business Practice. The three debt conceptions paint three disparate pictures of the real-world bondholder facing a restructuring-related wealth transfer. Under the traditional conception, the holder responds with equanimity. So long as interest checks and sinking-fund payments come in on schedule, the bondholder sees the drop in principal value as inore hypothetical than rcal. The investment conception, in contrast, nakes downgrading a disaster because downgrading substantially impairs the investment's value. The innocent holders respond with cries of anguish, lawsuits, and reform novements. Under the agency conception, with its rational actors and self-protective devices, the holders stay calm as they maintain their well-guarded defensive positions.

Evidence of rcal-world responses indicates that all three pictures contain some truth. As time has passed, however, the investinent coinmunity has moved away from an investment-based model to an agency model. Back in 1985 and 1986, when holders of high-grade corporate bonds first suffered wealth transfers, the "investment" response was prominent. The financial press reported anger anong institutional holders, who coinplained of "shock" and "disquiet."269 They felt that their interests were being ignored, ${ }^{270}$ and that they were "left holding the bag"271 and treated "like garbage."272 People who were supplying 50\% of the average enterprise's capital, they said, did not deserve such treatment. ${ }^{273}$ They made a classic policy argument for investor protection: if industrial concerns' long-term debt obligations came to involve one-way gainbles on restructuring risk, investors would avoid buying them, ${ }^{274}$ and industrials would pay higher interest rates as a result. ${ }^{275}$ These investors also lobbied for protection. In December 1986, the Fixed Incoine Analysts Society passed a so-called "Bondholders' Bill of Rights"-a resolution calling for fiduciary duties to protect all investors. ${ }^{276}$

the competing factors at stake in LBOs. See D. Baird, Fraudulent Conveyances and Leveraged Buyouts 10-17 (Feb. 2, 1989) (unpublished manuscript; copy on file in offices of the Duke Law Joumal).

269. Forsyth, Bad Grades: Takeovers Teach a Costly Lesson to Bond Holders, Barron's, Feb. 24, 1986, at 26, col. 1, col. 3.

270. Prokesch, supra note 192, at Al, col. 1, col. 1.

271. Id.

272. Boland, supra note 192 , at 10, col. 3 .

273. See id.

274. Instead, they would prefer treasuries and utlity bonds. Forsyth, supra note 269 , at 26 , cols. $3-4$.

275. Prokesch, supra note 192, at D4, col. 1; Farrell, supra note 191, at 114 ("it's only a matter of time" before bond market risks raise yields on corporate bonds as compared with Treasury securities (quoting Henry Kaufman of Salomon Bros.)).

276. See Letter from Fixed Income Analysts Society, Inc. to Members (n.d.) (copy on file in offices of the Duke Law Joumal) (reporting two-thirds approval of referendum on "Bill of Rights"); 
The complaining had hittle effect. Neither the courts, the Congress, nor the Securities Exchange Commission came to the rescue. Nor did covenants eliminating the restructuring risk appear in new issues right away. Managers of public bond issuers continued to resist covenants. As before, they searched for the underwriter willing to impose the fewest restraints.277 In 1988, investors in bonds issued after 1985 were still complaining of restructuring-related injury. ${ }^{278}$ Only following the great RJR Nabisco restructuring did a major institutional investor mount a lawsuit based on investor-protective principles. ${ }^{279}$

By 1988, however, stress on innocent imvestors' disempowerment and injury had begun to give way to the agency notion that those who fail to contract to protect themselves have only themselves to blame. In that year, several fund managers, reeling froin new restructuring-related mjuries, formed an "Institutional Bondholders Rights Association." This time, in contrast to the Fixed Incoine Analysts' earher call for a fiduciary duty, the investors called for collective action to stimulate the reappearance of effeetive protective covenants. Bondholders, they said, should be willing to accept a lower interest rate to get such covenants. The cost would be twenty-five basis points. ${ }^{280}$ If people would read trust indentures, one prominent manager said, proteetions would follow; those who look outside for help are "crybabies."281

This inoveinent shows promise. At institutional purchasers' insistence, protective covenants have begun to reappear in publicly sold bonds. ${ }^{282}$ Meanwhile, the rating agencies have been taking cognizance of

Letter from Fixed Income Analysts Society, Inc. to Members (Dec. 23, 1986) (copy on file in offices of the Duke Law Journal) (explaining the "Bill of Rights" and requiring that votes for or against be tendered by January 31, 1987); see also Bleiberg, Bondholders, Unitel Issuers Are Getting Away with Highway Robbery, Barron's, Nov. 24, 1986, at 9, col 1, col. 4 (discussing Society's work on the resolution).

277. Boland, supra note 192, at 10, col. 4; see also Roe, supra note 103, at 250 (junk bonds have few covenants); Taggart, supra note 135, at 11 n.4 (original-issue junk bonds have fewer covenants than investment-grade bonds).

278. Boland, supra note 192, at 10, col. 3; see Winkler \& Smith, Sore Junk-Bond Holders Form Rights Group but Say They Aren't Looking for a Free Ride, Wall St. J., June 30, 1988, at 61, col. 3 (bondholders banding together to protect investments from restructurings).

279. See supra note 8.

280. Winkler \& Smith, supra note 278; see also Zigas, The Bonds Most Investors Never Hear About, Bus. Wx., Sept. 19, 1988, at 152, 153 (public buyers, particularly institutions, insisting on covenants from issuers).

281. Winkler \& Smith, supre note 278.

282. Zigas, supra note 280 , at 153 . The novement to include covenants against restructuringrelated wealth transfers has already gone through two stages of development. A well-publicized new form of covenant, the "poison put," appeared after 1985 and quickly became common in publicly issued bonds. But this "poison put," in its standard form, protects bondholders only as a side effect of protecting management from hostile tender offers. Independent directors unay be able to waive a "poison put" to facilitate wealth transfers incident to defensive moves. See Clemens, Poison Debt: 
restructuring risk. The trading halts and wealth transfers that greeted the food coinpany restructurings of late 1988 gave this investor self-help movement additional momentum. ${ }^{283}$ At the same time, however, the very magnitude of this latest bondholder disaster shows just how far the movement has to go. ${ }^{284}$

In the wider investment commumity, the self-protective response has long dominated. Indeed, outside of the relatively small group of institutional managers who compose portfohios of bonds, no one seems to have considered the wealth transfers a significant problem. Given the prevalence of institutional holding 285 and diversification, the mjuries, while real, have not seemed painful. Covenants have not become more effective, but bond durations have dropped markedly, further limiting the impact of wealth transfers. ${ }^{286}$ To many observers, im fact, the years of restructuring have been good ones with respect to bond returns. A bull market in bonds lasted until 1987.287

We can infer that institutional perspectives have thus far determined market responses to restructuring-related injury. In the last three years, high-grade corporate bond portfolio managers who relied on past con-

The New Takeover Defense, 42 Bus. LAw. 747, 750-51, 753 (1987). Similar restructuring-related wealth transfers occurred in the seminal Revlon case, Revlon, Inc. v. MacAndrews \& Forbes Holdings, 506 A.2d 173 (Del. 1986). Such waivers have occurred in other cases as well, leaving behind surprised, injured bondholders. See Zigas, The One-Two Punch Pummeling Convertibles, Bus. WR., Feb. 8, 1988, at 82 .

In 1988, the bond market caught on to the limited protection offered by the "poison put." Herman \& Stine, Bonds Stage Rebound Amid Declining Oil Prices and a Hint That the Fed Isn't Tightening Credit, Wall St. J., Oct. 21, 1988, at C21, col. 4. According to one observer, "poison puts haven't been worth a bucket of warm spit." Winkler, supra note 2, at Cl, col. 5 (quoting Richard Wilson, inanager of corporate bond research at Merrill Lynch). Holders began to demand new protections. One proposal would effect rate increases to coinpensate for restructurings. Wallace, supra note 3, at D5, col. 3. Another proposal would give bondholders the privilege to put their bonds back to the issuer at the bonds' initial yield over specified Treasury securities. Id. When one issuer recently went to market with an effective-looking put provision, Moody's raised the issue's rating. Farrell, Miller \& Zigas, supra note 8, at 28.

283. See supra notes $3-4$ and accompanying text.

284. Even after the RJR Nabisco fiasco, one underwriter opined that effective covenants were still unlikely to appear: "It isn't clear that there is sufficient hoinogeneity of interest on either the buy ... side or sell ... side to have a poison put that is effective ...." Winkler, supra note 2, at $\mathbf{C l}$, col. 4 (quoting Curt Welling, managing director of First Boston Corp.).

285. According to Roe, institutions hold $90 \%$ of the bond market and $95 \%$ of the junk bond market. Roe, supra note 103, at 258-59 (citing BOARD OF GOVERNORS OF THE FED. RESERVE SYS., FLow OF FundS ACCOUNTS, FINANCIAL ASSETS AND Liabilimies, YEAR-END, 1961-1984).

286. The average years to maturity of corporate junk bonds have fallen from 19 years in the late 1970 s to 11 years in 1985, in response to the inflation of the late 1970s. See Taggart, supra note 135, at 11 n.4.

287. See Uchitelle, Bonds in Slump as Dollar Stirs Fear of Inflation, N.Y. Times, Apr. 23, 1987, at 1, col. 2. The new junk bond market gives all holders access to bonds offering three to five points over Treasury securities with upside potential if issuers' fortunes improve. THE EcoNomisT, June 11, 1988, American Capital Markets Survey, at 15 [heremafter Capital Markets Survey]. 
tracting practices have experienced something like the suffering of an underdiversified individual investor. To thein the wealth transfers at first looked tortious. Over time, however, this group has begun to adjust, albeit with noteworthy hesitation. Relying on the security of management's position no longer makes sense. The inarket price even of pre1985 bonds now secms partially to reflect restructuring risk. And holders of new debt issues can foresee and contractually control restructuring-related imjury; they cannot easily claim to have been victimized.

Significantly, prior to the RJR Nabisco transaction, no segment of the investunent community vigorously tried to get courts to reverse past wealth transfers. Not only the relatively unfavorable state of the law, but also the community's broader interests, explain this inaction. To inost market players, the agency conception captured the essence of the restructuring phenomenon all along. Individual investors lack a substantial stake in high-grade corporate bonds and stand to profit from restructurings as holders of securities that these transactions benefit. They view bondholder injuries as trivial, and self-protection as a norm apphicable to everyone but themselves. This picture becomes sharper where institutioual investors are concerned, especially the largest imstitutions-the "financial supermarkets." An institution might suffer from a wealth transfer in its capacities as mutual fund advisor and bondholder for its own account, while at the same time holding and advising portfolios of securities that restructurings benefit. Moreover, its investment banking arm might actively promote restructurings. For this institution as a whole, then, the wealth transfers will be Kaldor-Hicks-efficient. ${ }^{288}$ Restructuring gains will more than offset losses experienced in and around the bond portfohios. The bond losses will seem catastrophic only to the managers directly responsible for bond portfolios. And even to these inanagers, a downgrading is not the same thing as a payment default. Although the inarket value of the portfolio drops, the late 1970s inflation brought far worse losses. Overall, large institutions have no compelling stake in bondholder protection.

5. Summary. Corporate rights are based on clear and accessible pictures of imjury, featuring clearly modeled imjured individuals. Stockholders commonly appear in these pictures. But, somehow, there emerges no picture of a legal bondholder injury. Elements that could make up such a picture are present in the facts and the law. But the elements never quite coalesee. Instead, they disaggregate and disappear as the law remands bondholders to their contracts. However flawed as

288. See $\mathbf{R}$ PosNer, supra note 21 , at 12-14 (giving example of a Kaldor-Hicks-efficient transaction). 
protective documents, these contracts make self-protection technically easy for bondholders-easier than for stockholders. This situation makes bondholders seem virtually immune from tortious harm. By fixating on contracts, legal decisionmakers can handle conflicts over bonds without noticing the disparateness of bondholders as a class. Thus, real actors subject to real mjury stay comfortably far away. With stockholder disputes in contrast, real actors play a large role in the story; stockholder torts thus continue to occur despite contrary lessons from agency theory.

Nothing in legal theory dictates that this pattern of response continue. But then, nothing in theory or practice dictates its abandonment. The pattern endures because practieal forces support it. The investment community and most of its individual members want no barriers erected against restructurings. Corporate managers pursue their own interests; in so doing they oppose the investment community, but they do not thereby advance bondholder interests. Moreover, while there are plenty of bondholders, there is no bondholder interest group. Without institutional prompting, no bondholder tort will emerge; the theoretical case is too marginal to support spontaneous legal reform. The investment conception never quite provides a basis for a persuasive story of a right impaired; contmuing respect for the integrity of bond contract texts undermines its portrayal of injury. The securitized, agency vision of debt, in contrast, has enough real-world backing to rebut inferences of injury from wealth transfers.

This pattern breaks only with the application of fraudulent conveyance principles to LBOs. Here, traditional and investment considerations together determine the legal respouse. Traditional impulses suggest legal intervention when a firm becomes insolvent. But this intervention reflects a negative judgment on the desirability of high debt-equity ratios at least as much as a creditor-protective policy. An agency-based challenge to the insolvency standard questions this aversion to high-risk capital structures. Full explication of this issue requires consideration of the broader question of how corporate legal theory addresses the regulation of debt-equity ratios. This discussion follows.

\section{B. High Leverage and Corporate Law}

Historically, business theory and practice have valued conservative leverage. The theory changed in the 1960 s and 1970s, when financial economists denied that conservative leverage had intrinsic value. ${ }^{289}$ Business practice has recently followed suit, shifting toward higher leverage and looking to finance theory for legitimating ideas. Corporate law 
interferes with this business behavior only incidentally, by throwing up minor barriers like the fraudulent conveyance constraint against inarginal LBOs. According primacy to management discretion, corporate law has never imposed immediate constraints on leverage. It has assimilated pohcies favoring conservative leverage only at its inargins.

But the law rarely leaves inatters such as this coinpletely unregulated. It in effect stands back and watches events. It serves a mediating function, sanctioning free contracting ainong economic actors, provided that the free play causes no cognizable social ill. If, at soine future date, the new risk-prone business practices seem to entail excessive social costs, corporate legal theory will legitimate regulation, ${ }^{290}$ notwithstanding protests backed by financial economic theory.

\section{The New Debt-Equity Ratios.}

a. Evidence. The statistics establish beyond doubt that American businesses have inarkedly increased their leverage in recent years, and that they have broken longstanding financing patterns in doing so. First consider the broader picture. The standard measure of aggregate American indebtedness encompasses all obligations, public and private, other than those of financial intermediaries. This aggregate increased by an average of $11.8 \%$ per year during 1985,1986 , and 1987.291 This aggregate, expressed as a percentage of gross national product, yields an aggregate national debt-equity ratio. From 1945 to 1983, this figure stayed around 140\%.292 In fact, except for the Depression era, this figure has been stable for as far back into the nineteenth century as data are available. The figure began increasing in 1983.293 By 1988, it had risen to $181.4 \%$, a level previously experienced only in the early 1930s.294 The national debt-equity ratio is rising because businesses have increased their leverage in relation to net worth; most of this increase steins froin the corporate restructuring inovement.295

Now consider the corporate borrowers themselves. Their leverage has increased drainatically, by a number of measures. The traditional debt-equity ineasure-debt as a percentage of book value-states the

290. For further discussion of this mediating function of corporate law, see Bratton, Nexus of Contracts Appraisal, supra note 12.

291. Capital Markets Survey, supra note 287, at 28.

292. Id. at 27.

293. Although amounts of private and government debt have fluctuated, they were negatively correlated until 1980 . Then, as business debt began increasing, they became positively correlated. B. FRIEDMan, INCREASING INDEBTEdNESS aNd FINANCLAL STABILITY IN THE UNITEd STATES 4 (National Bureau of Economic Research Working Paper No. 2072, Nov. 1986).

294. Capital Markets Survey, supra note 287, at 27.

295. B. FRIEDMAN, supra note 293, at 12. 
most extreme case. In 1962, aggregate corporate debt was $58.2 \%$ of book value; in 1983, it was $73 \%$; in 1984 , it was $81.4 \% .296$ In the second quarter of 1988, net interest payments amounted to inore than $20 \%$ of corporate cash flow, a proportion equaled only in 1974 and 1982, recession years with high interest rates. ${ }^{297}$ The raw dollar amounts of borrowing have also seen dramatic increases. During 1984 and 1985, nonfinancial corporate debt rose $\$ 384$ billion, while equity shrank $\$ 99$ billion, despite retained earnings of $\$ 53$ billion and new equity issuance of negative \$152 billion. ${ }^{298}$ The number of LBOs, hallmark high-leverage transactions, rose froin 99 in 1981 to 308 in 1986; their total value increased from $\$ 3.1$ billion to $\$ 40.9$ billion. ${ }^{299}$ The original-issue junk bond, another tool in the high-leverage movement, took on a new role as a primary financing technique in large restructurings. From 1981 to 1984 , junk bond sales provided only $0.3 \%$ of takeover financing; by 1985 , this figure had risen to $13.6 \%$. Almost all of this growth occurred in junk bond financing of takeovers of larger corporations. In 1984, junk bonds provided $32.9 \%$ of the capital for these transactions. ${ }^{300}$

A few additional factors make this picture appear less startling. First, coinparisons of indebtedness with the market value, as opposed to the book value, of assets have not risen as markedly. For instance, in 1984 , the ratio of debt to asset replacement cost was $49.4 \%$, a level slightly below the peak figures of 1970-1972.301 Second, until October 1987, rising stock market values counterbalanced growth in corporate indebtedness. ${ }^{302}$ Third, even as the quantity of junk bonds has risen dra-

296. And more and more of the borrowing is short-term. In 1985, short-term borrowing had risen to $52 \%$ of the corporate total. Coffee, Corporate Web, supra note 190, at 41 .

297. America's Third Debt Bubble, THE Economist, Oct. 15, 1988, at 79 [hereinafter Debt Bubble].

298. Lipton, supra note 137, at 20-22.

299. EConomics Div., Cong. Research Serv., Library of CONGress, LeVERAGed Buyouts and the pot of Gold: Trends, Public Policy, andd Case Studies 17 \& tbl. I-3 (1987).

300. Office of the Chief Economist, SEC, Noninvestment Grade Debt as a SOURCE OF TENDER OFFER FinANCING, reprinted in [1986-1987 Transfer Binder] Fed. Sec. L. Rep. (CCH) I 84,011 (June 20, 1986).

The 1987 stock market crash caused a lull in the amount of junk bond financing, but before the end of the first quarter of 1988, takeover activity picked up again, and junk bond issuance picked up with it, although buyers demanded higher quality or higher returns. Cowan, Signs of a Revival for Junk Bonds, N.Y. Times, Mar. 10, 1988, at D2, col. 1.

301. Coffee, Corporate Web, supra note 190, at 44-45. The debt-to-equity ratio for 1970-1972 exceeded $50 \%$ on a current-value basis. Id.

302. See B. FRIEDMAN, supra note 293, at 14 . The ratio of debt to market value of equity peaked at $106 \%$ in the 1974 bear narket. It stood at $83 \%$ in 1984, and at $75 \%$ in 1988 . Farrell, Learning to Live with Leverage, Bus. WK., Nov. 7, 1988, at 138, 139. 
matically, the junk bond default rate has stayed comfortably low. ${ }^{303}$

b. Policy. Increased corporate indebtedness has not yet had an obvious effect on financial stability. ${ }^{304}$ Although no crisis has occurred, commentators have paid considerable attention to the question whether increased indebtedness creates an unjustifiable risk of a crisis. These analyses divide into three positions-high pessimism, guarded pessimism, and optimism.

The high pessimists assert that high debt itself creates a risk of financial crisis. They foresee this scenario: as the quantity of debt contmues to grow, creditors will at some point lose confidence and abruptly withdraw their funds from the credit inarkets, causing a drastic curtailment of economic activity. ${ }^{305}$ Significantly, those who fear this result also express the traditional judgment that there is "something wrong" with borrowing. Borrowing stems from weakness and creates risk. Equity, in contrast, stems from strength and creates security. Thus, according to Henry Kaufman, the present heavy debt load undermines the "integrity" of our financial system; it signifies that those in authority evade their "responsibilities." 306 Senator Proxmire, too, condemns the increase in nonfinancial debt as a weakness. 307 John Kenneth Galbraith coinpares contenporary events to the most notorious debt disaster of the this century, the utility pyramiding of the 1920 s and 1930s.308 And Felix Rohatyn worries that the increased borrowing occurs during a period of global competitive difficulty for American businesses. He expresses dismay: "Maybe I'm getting old . . . but, boy, I think that's crazy." 309

Guarded pessimists worry about the incremental effect that higher debt load will have during a cyclical downturn in the econoiny's nonfi-

303. For the period 1974-1985, the junk bond default rate was $1.53 \%$; the rate for all publicly issued bonds during this period was .09\%. Taggart, supra note 135 , at 12 .

Junk bond yields have remained attractive, the default rates implied in junk bond interest rates have exceded the default losses actually experienced. Fons, The Default Premium and Corporate Bond Experience, 42 J. Fin. 81, 96 (1987).

304. B. FRIEDMAN, supra note 293, at 14.

305. Capital Markets Survey, supra note 287, at 28.

306. Financial Restructuring; Hearings on Takeover Activity: Major Policy Issues Before the Subcomm. on Telecommunications, Consumer Protection and Finance of the House Comm. on Energy and Cammerce, 99th Cong., 1st Sess. 383 (1985) (statement of Henry Kaufman, Executive Director, Salomon Bros.).

307. The Effect of Mergers on Management Proctices, Cost, Availability of Credit, and the LongTerm Viability of American Industry: Hearings Before the Subcomm on Securities of the Senate Comm. on Banking, Housing, and Urban Affairs, 99th Cong., 1st Sess. 135 (1985) [hereinafier Securities Subcommittee Hearings].

308. See Galbraith, The 1929 Parallel, Atzantic Monthly, Jan. 1987, at 62, 64; Uchitelle, Pushing the Stakes to New Heights, N.Y. Times, Oct. 30, 1988, § 3, at 1, col. 2.

309. Securities Subcommittee Hearings, supra note 307, at 726. 
nancial performance. Under this view, debtors' distress will contribute to, but will not itself cause, a decline in nonfinancial economic activity. ${ }^{310}$ A downturn will cause cash flow problems for debtors. When they fail to pay, they will cause their creditors to have cash flow problems. Further curtailment of economic activity will result. In addition, forced asset sales by strapped debtors will depress asset prices. ${ }^{311} \mathrm{~A}$ wave of bankruptcies will follow. ${ }^{312}$ In Friedman's view, the magnitude of today's debt load makes the prospect of widespread debtor distress intolerable as a matter of financial policy. Under this view, the new indebtedness in the end encourages expansionary inonetary policy and inflation..$^{313}$

Optimistic observers put a different interpretation on the guarded pessimists' scenario. Since debt does not itself cause financial crisis, any "problein" with high debt will solve itself if the economy has a period of sustained growth. Given economic growth, along with a plateau in borrowing activity, aggregate indebtedness will drop back to historical levels as a matter of course. ${ }^{314}$ Some go further, arguing that serious disruption should not occur even if the economy turns down in the short run. The recent increases in leverage are concentrated in the corporate sectors best able to withstand a recession-manufacturers of nondurables, utilities, and financial services. 315 Proponents of the restructuring novement add that the restructurings themselves will help to keep the economy buoyant, because the discipline that restructurings bring stimulates productivity. ${ }^{316}$ The stock market will respond favorably to these productivity gains, and cash flow will keep pace with higher interest costs. ${ }^{317}$

The high pessimists have not had much practical influence during the past few years. Widespread, sustained discussion of law reform to

310. Congressional Research Serv., library of Cong., Corporate Debt: A Profile of MANOR INDICATORS 2, 4-5 (1986) [hereinafter CRS, DEBT Profile] (views of John Shad, Chairman of the SEC, and Paul Volcker, Chairman of the Board of Governors of the Federal Reserve System); Coffee, Corporate Web, supra note 190, at 44-45.

311. B. FriedMaN, supra note 293, at 19-24.

312. A recent study, applying assumptions drawn from the 1973-1974 recession, predicts that $10 \%$ of American corporations would become insolvent in such circumstances. Debt Bubble, supra note 297 , at 79.

313. B. Friedman, supra note 293, at 19-24; see also Roe, supra note 103, at $233 \mathrm{n} .2$ ("junk bonds heighten related macroeconomic risks," such as inflation).

314. B. FRIEDMAN, supra note 293, at 19-24 (warning of debtor distress in a few industries even under this scenario).

315. Don't Panic on Debt, The Economist, Dec. 3, 1988, at 79.

316. CRS, DEBt PROFIL, supra note 310, at 8 (citing Morgan Stanley report); Uchitelle, supra note 308, at 8, col. 3 (views of Michael Jensen, economist, Harvard Business School). The experiences of Philhps Petroleum and Burlington Industries serve as exemplars. Debt Bubble, supra note 297 , at 80 .

317. Coffee, Corporate Web, supra note 190, at 44-45. Optimists also note that corporate debtequity ratios in Japan, West Germany, and Canada still are substantially higher than in the U.S. Debt Bubble, supra note 297, at 79. 
lessen the dangers of high leverage started only after the RJR Nabisco shock. Reforms that could reduce the leverage incentive could take place without technical problems. To remove much of the leverage incentive, Congress just has to eliminate the differential treatment of debt and equity in the tax code, whether by making interest payments nondeductible or by making dividend payments deductible. ${ }^{318}$ Not that restructurings were exempt from criticism before RJR Nabisco. But critics have tended to attack the restructuring movement for its destabilization of productive institutions rather than for the aggregate levels of nonfinancial indebtedness it produces and consequent effects on financial stability. They attack the transformation of equity into debt, for diverting capital from direct investment in "economic development" and "job creation."319 Junk bonds are thought problematic as holdings, rather than as issues. ${ }^{320}$ The critics suggest only piecemeal solutions to these probleins. ${ }^{321}$

This policy talk reflects a shift in thinking about debt and its associated risks. The grave suspicions of the high pessimists, particularly their concern with confidence and integrity, previously dominated both financial theory and busimess practice. Now this approach amounts to a rearguard critique by the "heavy hitters" of an earlier generation. Today's

318. See CRS, RECENT TRENDS, supra note 220, at 3; see also SEC Must Report by May 1 on LBO-Related Regulatory Action, 21 Sec. Reg. \& L. Rep. (BNA) No. 14, at 512 (Apr. 7, 1989) (discussing forthcoming SEC report on changes in regulation of LBOS); Lipton, supra note 137, at 63 (interest deduction for debt financing of hostile takeovers should be eliminated).

319. Taggart, supra note 135, at 5 (quoting letter signed by twelve U.S. Senators); see also Proxmire, What's Right and Wrong About Hostile Takeovers?, 1988 WIs. L. REv. 353, 358-60.

320. Regulators worry about purchasers-purchasers who are uninformed about risks, as with small investors, and purchasers who are too ready to take risks at someone else's expense, as with federally insured financial institutions. See Coffee, Corporate Web, supra note 190, at 45 (savings and loans and pension funds receive capital from individuals protected by federally funded insurance). In late 1986, the $\$ 120$ to $\$ 125$ billion of junk bonds outstanding were held as follows: insurance companies held \$40 billion; pension funds held \$10 to \$15 billion; unutual funds beld \$40 billion; savings and loans held $S 10$ billion; individuals held $\$ 15$ billion. Id. at $45 \mathrm{n} .119$. The moral hazard problem arises with the savings and loan holdings, which are heavily concentrated among a few large savings and loans. Taggart, supra note 135, at 17-18.

321. Suggestions include applying the margin rules to high-yield securities and limiting federally insured institutions' boldings of high-yield debt. See CRS, RECENT TRENDS, supro note 220, at 3.

Post-RJR Nabisco discussions of high debt show increased sensitivity to issues of risk. The RJR transaction raises questions about the continuing efficacy of the safeguards that were built into earlier restructuring-related borrowing waves. Restructured coinpanies do not generally expect to retain their extreme debt-equity ratios permanently. They usually pay down their borrowings during the first few years and return to debt-equity ratios near or below the danger level. The economy's aggregate default risk arguably stays tolerable as long as each generation of restructured enterprises achieves this pay-down. The problem, of course, is that an economic downturn can disrupt this paydown process, causing widespread financial reverses. RR Nabisco destabilized the perception of safety by making the problem of such a disruption harder to ignore: the RUR borrowings are so large and the business cycle so mature that the limited-damages perception becomes implausible, particularly given the prospect of future rounds of restructuring. 
mainstream observers drop the moralism and Jessen anxiety by viewing debt as a neutral financing instrument, one of many devices that can support low-cost production. These observers thus take a financial economic approach to debt. By justifying high leverage, financial economics challenges, and at least for the moment overtakes, the traditional and investment conceptions' contrary advice. The following discussion addresses this theoretical shift and its implications.

2. High Leverage in Financial Theory and Practice. According to agency theory, the restructuring movement makes debt an instrument of reform. ${ }^{322}$ Entrenched managers, employing conservative financial policy, make suboptimal investments to suit their own interests rather than those of their primcipals. Restructurings force management to change this investinent practice, and high leverage facilitates restructuring. This view includes an implicit judgment that no internal norms necessarily dictate debt policy. Debt serves other ends in the struggle for corporate dominance-those of management and those of actors in the capital markets.

This view displaces a contrary, once generally accepted, managerialist view. The managerialist view involves a different set of behavioral assumptions. It asserts that corporate actors' risk preferences should dictate financial policy, and that, in fact, managers and equity holders have a common interest regarding debt. A little leverage lowers financing costs, and maximizes a firm's value for both groups. High leverage jeopardizes the firm's stability, making equity less valuable. Given risk aversion on everyone's part, good managers look for an optimal, moderate level of debt. ${ }^{323}$ The managerialists saw this approach as a lesson of history.

a. The managerialist view. Heavy debt was viewed as imprudent Jong before management corporations appeared at the turn of the century. 324 Prudence followed from the traditional conception, with its flesh-and-blood, mutually suspicious debtors and creditors. High leverage invited the destabilizing, opportunistic conduct that traditional debtor-creditor law regulated. The occurrence of serious financial dislocations during the early years of the twentieth century reinforced the application of the prudent view to the new mass-producing corporations. Many corporations went imto reorganization. In response, the new man-

322. See supra notes $228-40$ and accompanying text.

323. See A. Barnea, R. Haugen \& L. Senget, supre note 139, at 2; R. Marris, Economic THeORY GF MaNiagerial CApitalism 7-9 (1964).

324. See, eg., Hun v. Cary, 82 N.Y. 65, 77-79 (1880) (borrowing for investment of questionable value violates directors' duty of care). 
agement groups made preservation of the corporate entity against bankruptcy and reorganization a major concern. Given fluctuations in the business cycle, achieving this goal demanded conservative financial policy:325 the lower the debt-equity ratio, the more secure the firm. The conventional wisdom called for firms to incur long-term debt only when absolutely necessary, and to retire it as quickly as possible. ${ }^{326}$

Subsequent cyclical downturns in 1920-1921 and 1929-1933 reinforced the lesson of the adverse consequences of trading on the equity. Public utility and railroad holding coinparies, built up during the $1920 \mathrm{~s}$ only to collapse during the 1930s, were powerful object lessons supporting the prudent view. The holding companies were pyramids of corporate entities, constructed to magnify the financial leverage of sinall groups of equityholders. ${ }^{327}$ The managers and investment bankers who built them claimed to be providing a means of efficient operation, but the Depression experience proved them wrong. Dozens of utility coinpanies failed, even though industry revenues dropped only $15 \%$ froin their highest historical levels. ${ }^{328}$

The public utility bankruptcies resnlted in a rare event of direct federal regulation of corporate capital structures, the Public Utility Holding Conipany Act of 1935.329 This statute instantiated the prudent view. It required the reorganized comparries to have "balanced" capital structures, with substantial common stock "insuring" against bankruptcy. Fortunately, the "insurance" was cheap: in view of investors' risk aversion, "balanced" capital structures were the most cost-effective in any event. ${ }^{330}$

325. See A. DEwING, supra note 25 , at 742.

326. See J.F. WESTON, THE SCOPE AND METHOdOLOGY OF FINANCE 23-24 (1966).

327. Id. at 25. By 1931, five public utility lolding companies were controlled by the holders of stock worth less than one percent of the companies' total assets. J. SELIGMAN, THE TRANSFORMATION OF WALI STREet: A History OF THE SECURITIES AND EXChANGE COMMISSION AND MODERN CORPORATE FINANCE 128 (1982).

328. J. SeLJGMAN, supra note 327 , at 127-28. 53 public utility holding companies went into bankruptcy and 23 underwent workouts. Id.

329. Ch. 687, 49 Stat. 803 (codified at 15 U.S.C.A. $\$ \S 79-79 z-6$ (West 1981 \& Supp. 1988)). The case is rare because the twentieth-century American norm leaves corporate debt levels to management discretion, subject to intervention at insolvency. See supra notes 23-24 and accompanying text. The law makes an exception for financial intermediaries-banks, insurance companies, and savings and loans. The law regulates these institutions' capital structures because the institutions' creditors are members of the public who need special protection from the dangers of risky management. Clark, supra note 66 , at 560 n.156. Nineteenth-century legal capital rules, in contrast, sometimes imposed mandatory limits on debt. See supra text accompanying note 46.

330. J. SELIGMAN, supra note 327, at 261. For an example of 1935 Act jurisprudence, see In re Consumers Power Co., 6 S.E.C. 444 (1939).

Significantly, the prudent view survived the evolution to unanagerialist thinking tht took place during the 1920 s and 1930s. This prudent view followed froun the investment conception of debt as well as from the traditional conception. Creditors, conceived as investors, join in a common enter- 
The prudent view held sway both in textbooks and in boardrooms for over thirty years, even as memories of the 1930s lingered. Postwar recessions served as reminders of the continuing danger. ${ }^{331}$ Management followed a simple rule of thumb as it financed its growth-a dollar of new equity for every new dollar of debt.

b. The financial economic critique. The pattern broke in the mid1960s. ${ }^{332}$ The theory changed radically. The practice changed slowly.

Financial economics rebuts the prudent approach's basic assumptions by using the rational economic actors of neoclassical microeconomics and analyzing their behavior when faced with financing and investing choices. Rational economic actors do not share managerialist investors' risk preference profile: instead, their preferences range along an indifference curve. Breaking with the prudent investor profile, some investors opt for higher risk and a higher coupon rate. ${ }^{333}$

Under the irrelevance hypothesis, debt has no intrinsic value to a firm as a financing tool. ${ }^{334}$ Even though an optimal aggregate level of debt may exist for the corporate sector as a whole, individual firms are indifferent to their debt levels. ${ }^{335}$ This theory seems to counsel equityladen capital structures; all other things being equal, why not be prudent? But in practice, all other things are not equal. Given the tax deductibility of debt, high leverage pays.

Agency theory modified this point shightly, holding that leverage makes sense up to the point when the risk of bankruptcy looms so large that discounted marginal increases in bankruptcy costs exceed tax savings. 336 Yet, this optimal leverage point can be rather high. Jensen and Meckling articulated the basic agency justification for heavily leveraged restructurings in their prescient 1976 article. Given management's tendency to shirk, debtholders' fixed claims should dominate over equityholders' interests, because debt inhibits management misconduct and saves taxes as well. ${ }^{337}$ And, the authors speculated, the bankruptcy cost barrier is not as formidable as the managerialist picture suggests. Bank-

prise with managers and stockholders. See supra notes $81-83$ and accompanying text. Prudence prevails in order to protect creditors' security and promote the common enterprise; in effect, prudence becomes a component of investor protection.

331. J.F. WESTON, supra note 326, at 23.

332. Profit margins and opportumities in many industries shrank. New management methods encouraged experimentation. Id. at 30.

333. See Levmore, supra note 161 , at 51.

334. See supra note 139 and accompanying text.

335. Miller, Debt and Taxes, 32 J. Fin. 261, 268-69 (1977).

336. Litzenberger, supra note 141, at 66.

337. Jensen \& Meckling, supra note 148, at 330-31. 
ruptcy costs are small ${ }^{338}$ and thus not a major determinant of capital structure.

Agency theory also removes the stigma of disgrace and failure from bankruptcy. In the nexus-of-contracts firm, debt and equity, as financial inputs, have fundamental similarities. Debt presents no special threat; it is merely equity with a fixed claim and a higher priority. ${ }^{339}$ In accord with this approach, bankruptcy becomes a contract performance problem stemming from the debtor's cash-flow shortfall. ${ }^{340}$ Faced with a contract performance problem, rational economic actors do not wring their hands about failure. They sit down and work out low-cost solutions.

c. Managerialism and financial economics compared. Managerialism and financial cconomics begin with different conceptions of the corporation. The managerialist corporate entity has a cognizable separate existence. Management has the expertise that makes mass production possible; to put that expertise to use, management must command. The corporate entity facilitates management action; it therefore has value and

338. Id. at 341; see supre note 160 (Wamer's study); see also Levmore, supra note 161, at 65-68 (summarizing Jensen and Meckling's model).

Jensen argues that firms that become insolvent after failed restructurings will incur lower costs than those experienced in the past. Jensen, Is Leverage an Invitation to Bankruptcy? On the Contrary-It Keeps Shaky Firms out of Coun, Wall St. J., Feb. 1, 1989, at A14, col. 3. He compares an insolvent company with an $85 \%$ debt ratio to an insolvent company with a $20 \%$ debt ratio; both companies have the same liquidation value, $10 \%$ of gomg-concern value. At the time the less leveraged company becomes insolvent, "it is . . . likely that its value is below its liquidation value." Actual liquidation might follow "with all its attendant conficts and dislocation." Id. The highly leveraged firm, in contrast, will be reorganized, probably through an out-of-court agreement in order to protect its high going-concern value. At worst, this firm will undergo the additional costs of a bankruptcy reorganization. Jensen adds that even in such a case, the reorganization process can cause beneficial management changes, id. at A14, col. 5, and that, because of the leadership of "organizations such as Drexel Burnham Lambert," innovative contract solutions can be expected when restructured companies fail. See id. at col. 4.

Jensen implies that we need not expect restructuring-related indebtedness to result in excessive bankruptcy costs, provided that the government does not intervene. But Jensen's cost picture does not provide strong support for his implication. The econoumies of workouts and reorganization that Jensen describes are not new to the restructuring era. Indeed, high pessimists, guarded pessimists, and all other observers who suggest that today's restructuring might result in significant future costs, use a scenario much like Jensen's. The more pertinent comparison would seem to be between a firm with $85 \%$ debt and an otherwise identical firm with a $50 \%$ to $60 \%$ debt. In an economic downturn, the latter firm avoids the reorganization costs incurred by the more highly leveraged firm. Investors in the more highly leveraged firm would be better off than investors in the moderately leveraged firms only if agency-cost savings from the highly leveraged firm's restructuring outweighed its subsequent reorganization costs.

339. Lehn, Blackwell \& Mart, supra note 148, at 173; see also supra notes $167-72$ and aecompanying text.

340. Lehn, Blackwell \& Marr, supra note 148, at 175. 
is worth preserving. ${ }^{341}$ Debt is intrinsically problematic because it threatens the entity's integrity, just as inortgage debt threatens the household of the breadwinner who signs the note. Like the household, the nanagerialist firm is an institution worth protecting against outside disruption. The managerialist corporation, then, not only reified the traditional debtor-creditor relationship, but also adopted the traditional ethic of prudence regarding debt.

Financial economics, in contrast, deconstructs the managerialist corporate entity, reducing it to a reference point where factors of production meet and contract. Management becomes just one of the factors of production. ${ }^{342}$ Debt becomes just another cluster of terms in a wider structure of contracts. It jeopardizes nothing of value, since contracting can deal with any performance problems. Financial economics characterizes default and bankruptcy not as terminating events, but as negotiations with determinable costs. This perspective inakes debt prudence irrational unless the costs of default are in fact very high.

Theoretically, both approaches have considerable appeal. One practieal difference separates them, however: managerialist prudence has a basis in history as well as in theory. Reorganizations during the inanagement corporation's formative period brought houne the riskiness of debt. Agency theory, in contrast, counsels corporations to take on more debt, relying on an insufficiently proven assertion about bankruptcy costs. No thoroughgoing study of contemporary direct and indirect bankruptcy costs supports this counsel. ${ }^{343}$ Moreover, a substantial body of opmion considers these costs significant. ${ }^{344}$ Given a long, complex reorganization proceeding, bankruptcy involves substantial costs beyond those apparent from a review of checks written by the treasurer of a debtor in possession. These costs include lost sales and other incoine losses from financial stress and perceptions of such stress in various markets. ${ }^{345}$ No one really knows whether the new debt-equity ratios will result in material costs in the event of a substantial economic downturn. Nor does anyone know how much of this bill will fall upon society.

341. See generally Bratton, Nexus of Contracts Appraisah supra note 12 (outlining development of managerialist conception).

342. See supra note 147 and accompanying text.

343. Significantly, many institutional changes this century have reduced dislocations from bankruptcies. Under current law, reorganization not only keeps creditors at bay and the productive entity producing, but it also keeps management on the job. See 11 U.S.C. § 1108 (1982 \& Supp. IV 1986) (debtor in possession operates business unless court orders otherwise).

344. See, e.g. R. BrEAlEY \& S. MYERS, supra note 81, at 395; Litzenberger, supra note 141, at 61.

345. Litzenberger, supra note 141 , at $61-62$. 
The discussion thus comes down to the matter of risk. Although not risk-prudent, the new debt-equity ratios are not irrational. They entail a calculated risk. But acknowledging this element of calculation does not by itself justify the risks. Even risks rationally assumed can come to pass, causing regrets in the risk-assuming actors. Furthermore, unlike the actors of financial economics, real-world investors are not completely rational, especially at extreme upsides and downsides where large amounts of wcalth are staked on events at the margin. In the end, despite the assurances of financial economics, we have no guarantee that the new debt-equity ratios will represent a healthy break with and improvement on the past, rather than a repeat of the speculative excesses of the 1920s.

Lawmakers, meanwhile, carry on in the traditional inode, watehing impassively. The debt-equity experiment falls within the traditional zone of business discretion. If the experiment fails, legal regulation will follow, possibly following past patterns, ${ }^{346}$ but certainly notwithstanding any finance theory to the contrary.

\section{CONCLUSION}

Corporate law, like all law, exists in time. We receive it from the past. It governs the present. It allows for the future. It synchronizes past practices, present pressures, and future contingencies against an unfolding background of values.

At present, the great question facing corporate lawmakers is whether, in the long run and in the aggregate, the restructuring moveInent will create value or inflict injury. Of course, the question cannot be answered, simce economic science falls well short of the task. We opine and hope that value will be created. But, at the same time, we know and fear that tomorrow's economic downturn could make us regret today's transactions.

The law with which we structure our economic relatious helps us cope with this imperfect economic understanding. Today the law tolerates risky capital structures, but it does so without denying past disasters. Today's risky practices have no permanent, immutable basis in right. The law therefore holds open the possibility of future intervention against today's transactional patterns. During the past decade, constraining policies of investor protection have yielded to the market's securitization experience, clearing the way for restructurings. During the next decade, today's toleration of risky transactions might likewise yield

346. See supra notes 329-30 and accompanying text for the most prominent example of past regulation. 
to an experience of disruptive default, clearing the way for a new era of financial regulation.

Legal tolerance of restructuring-related wealth transfers also has a contingent aspect. The restructurings have made once basic assumptions regarding corporate debt relationships inaccurate. This change has destabilized these relationships and destroyed their previous pattern of reciprocity. The law currently tolerates the situation for several reasons. First, we remain comfortable with the traditional conception of debt relationships. Second, financial economics explains away the short-run injuries. Third, in the long run, these relationships might very well resolve themselves without costly and confusing legal intervention. Finally, any legal intervention would have to draw much of its normative imipetus from the relational value of soldarity. This value, basic to the investment conception of corporate debt, stems from and proinotes mutual respect and support among the participants of each corporate enterprise. Solidarity has been noticeably absent from contemporary financial relationships.

Indeed, the restructuring movement presupposes diminished solidarity in economic relationships. Today's corporate tycoons take value for their own accounts from producing institutions and others interested in them, including bondholders. Today's commentators justify this appropriation by asserting that enforced solidarity would inhibit wealth creation and cost-reductive reform. Legal theory's disaggregation of the corporation into a nexus of contracts shapes and supports this pattern of thought. ${ }^{347}$

Perhaps diminished sohdarity will, as the commentators suggest, facilitate this country's return to a coinpetitive posture. Even so, the diminution need not be permanent: should the restructuring movement achieve its apparent goal of low-cost production, a reordering of values could follow. Consciousness also could shift without such a functional invitation; lawmakers could find individnal profit taking from productive institutions unsatisfactory on some other new grounds. In either event, solidarity could return as a determining value in corporate law and practice, playing a remedial role in a wider institutional reconstruction. The investnient community's insecure, questioning response to the $R J R$ Nabisco affair may signal a change in this direction.

Renewed solidarity in financial relationships would militate against further toleration of wealth transfers that harm bondholders. Significantly, the law could change overnight to conform to a shift in values.

347. This, of course, marks a change from earher patterns of thought-patterns that prevailed when America was by far the world's most productive country. 
Judges can constrain injuries to bondholders without abandoning traditions of judicial restraint. Existing law contains the necessary tools. 